\title{
Middle Bronze Age land use practices in the northwestern Alpine foreland - a multi-proxy study of colluvial deposits, archaeological features and peat bogs
}

\author{
Sascha Scherer $^{1,2}$, Benjamin Höpfer ${ }^{2,3}$, Katleen Deckers ${ }^{4}$, Elske Fischer ${ }^{5}$, Markus Fuchs $^{6}$, \\ Ellen Kandeler $^{7}$, Jutta Lechterbeck ${ }^{8}$, Eva Lehndorff ${ }^{9}$, Johanna Lomax ${ }^{6}$, Sven Marhan ${ }^{7}$, \\ Elena Marinova $^{5}$, Julia Meister ${ }^{10}$, Christian Poll ${ }^{7}$, Humay Rahimova ${ }^{9}$, Manfred Rösch ${ }^{11}$, \\ Kristen Wroth $^{4}$, Julia Zastrow ${ }^{12}$, Thomas Knopf ${ }^{2,3}$, Thomas Scholten ${ }^{1,2}$, and Peter Kühn ${ }^{1,2}$ \\ ${ }^{1}$ Department of Geosciences, Chair of Soil Science and Geomorphology, Eberhard Karls University Tübingen, \\ Rümelinstraße 19-23, 72070 Tübingen, Germany \\ ${ }^{2}$ SFB 1070 RessourcenKulturen, Eberhard Karls University Tübingen, \\ Gartenstraße 29, 72074 Tübingen, Germany \\ ${ }^{3}$ Institute of Pre- and Protohistory and Medieval Archaeology, Eberhard Karls University Tübingen, \\ Burgsteige 11, Schloss Hohentübingen, 72070 Tübingen, Germany \\ ${ }^{4}$ Institute for Archaeological Sciences, Eberhard Karls University Tübingen, \\ Hölderlinstr. 12, 72072 Tübingen, Germany \\ ${ }^{5}$ Laboratory for Archaeobotany, Baden-Württemberg State Office for Cultural Heritage, \\ Fischersteig 9, 78343 Gaienhofen-Hemmenhofen, Germany \\ ${ }^{6}$ Department of Geography, Justus Liebig University Gießen, Senckenbergstraße 1, 35390 Gießen, Germany \\ ${ }^{7}$ Institute of Soil Science and Land Evaluation, Department of Soil Biology, University of Hohenheim, \\ Emil-Wolff-Straße 27, 70593 Stuttgart, Germany \\ ${ }^{8}$ Museum of Archaeology, University of Stavanger, Peder Klows gate 30A, 4036 Stavanger, Norway \\ ${ }^{9}$ Chair of Soil Ecology, University of Bayreuth, Dr.-Hans-Frisch-Straße 1-3, \\ 95448 Bayreuth, Germany \\ ${ }^{10}$ Department of Geography and Geology, Chair of Physical Geography, Julius Maximilians University \\ Würzburg, Am Hubland, 97074 Würzburg, Germany \\ ${ }^{11}$ Institut für Ur- und Frühgeschichte und vorderasiatische Archäologie, Ruprecht-Karls-Universität \\ Heidelberg, Sandgasse 7, 69117 Heidelberg, Germany \\ ${ }^{12}$ Institute for Archaeological Sciences, AG Archaeozoology, Eberhard Karls University Tübingen, \\ Rümelinstraße 23, 72070 Tübingen, Germany \\ Correspondence: Sascha Scherer (sascha.scherer@uni-tuebingen.de)
}

Received: 21 November 2020 - Discussion started: 6 January 2021

Revised: 2 May 2021 - Accepted: 10 May 2021 - Published: 28 June 2021

\begin{abstract}
This paper aims to reconstruct Middle Bronze Age (MBA; 1600-1250 BCE) land use practices in the northwestern Alpine foreland (SW Germany, Hegau). We used a multi-proxy approach including the analysis of biogeochemical proxies from colluvial deposits and buried topsoils in the surroundings of the well-documented settlement site of Anselfingen and off-site pollen data from two peat bogs. This approach allowed for in-depth insights into the MBA subsistence economy and shows that the MBA in the northwestern Alpine foreland was a period of establishing settlements with sophisticated land management and land use practices. The reconstruction of phases of colluvial deposition was based on ages from optically stimulated luminescence (OSL) and radiocarbon $\left(\mathrm{AMS}^{14} \mathrm{C}\right)$ dating from multi-layered colluvial deposits and supports the local archaeological record with the first phase of major colluvial deposition occurring during the MBA followed by phases of colluvial deposition during the Iron Age, the Medieval period and modern times. The on-site deposition of charred archaeobotanical
\end{abstract}


remains and animal bones from archaeological features, as well as polycyclic aromatic hydrocarbons (PAHs), charcoal spectra, phytoliths, soil microstructure, urease enzymatic activity, microbial biomass carbon $\left(\mathrm{C}_{\mathrm{mic}}\right)$ and heavy metal contents from colluvial deposits, were used as proxies for on-site and near-site land use practices. The charcoal spectra indicate MBA forest management which favored the dominance of Quercus in the woodland vegetation in the surrounding area north of the settlement site. Increased levels of $5 \beta$ stanols (up to $40 \%$ ) and the occurrence of pig bones (up to $14 \%$ ) support the presence of a forest pasture mainly used for pig farming. In the surrounding area south of the settlement, an arable field with a buried MBA plow horizon (2Apb) could be verified by soil micromorphological investigations and high concentrations of grass phytoliths from leaves and stems. Agricultural practices (e.g., plowing) focussed on five staple crops (Hordeum distichon/vulgare, Triticum dicoccum, Triticum monococcum, Triticum spelta, Triticum aestivum/turgidum), while the presence of stilted pantries as storage facilities and of heat stones indicate post-harvest processing of cereal crops and other agrarian products within the settlement. In the area surrounding the settlement, increased levels of urease activity, compared to microbial biomass carbon (up to $2.1 \mu \mathrm{g} \mathrm{N} \mu \mathrm{g} \mathrm{C}_{\text {mic }}^{-1}$ ), and input of herbivorous and omnivorous animal faeces indicate livestock husbandry on fallow land. The PAH suites and their spatial distribution support the use of fire for various purposes, e.g., for opening and maintaining the landscape, for domestic burning and for technical applications. The off-site palynological data support the observed change in on-site and near-site vegetation as well as the occurrence of related land use practices. During the Early and Middle Bronze Age, fire played a major role in shaping the landscape (peak of micro-charcoal during the MBA), and anthropogenic activities promoted Quercus-dominated forest ecosystems at the expense of natural beech forests. This indicates a broader regional human influence in the northwestern Alpine foreland at low- and mid-altitude inland sites during the Middle Bronze Age.

\section{Introduction}

Human use of land has profoundly altered terrestrial ecosystems since the Late Pleistocene and Early Holocene (Ellis et al., 2011; Redman, 1999). The emergence of sedentism and agricultural practices has intensified this trend, at least since population sizes and technological capabilities have increased (Ellis et al., 2013). In the northwestern Alpine foreland, most Middle Bronze Age (MBA; 1600$1250 \mathrm{BCE}$ ) settlements are known from sites with aerobic soil conditions further inland, while the lakeshores and bogs were widely depopulated during this period (Menotti, 2001; Köninger, 2015). However, weathering processes and aerobic soil conditions limit the preservation of archaeological finds, organic remains and biogeochemical proxies (Jansen and Wiesenberg, 2017). Therefore, rather little on-site and near-site (distance $<5 \mathrm{~km}$ to the site) archaeopedological and archaeobotanical evidence has been available so far for MBA settlements in the northwestern Alpine foreland. Additionally, the information from off-site (distance $>5 \mathrm{~km}$ to the site) proxies is more closely related to the vicinity of lakes and bogs than to settlements further inland (Rösch, 2013; Tinner et al., 2003).

One approach to overcome these drawbacks is the analysis of colluvial deposits and buried topsoils as archives for the reconstruction of past land use practices, close to documented settlement sites (Kittel, 2015, Ponomarenko et al., 2020). With respect to the diverse definitions of colluvial deposits as hillslope sediments transported by either massgravity transport or slope-wash-type processes (Miller and
Juilleret, 2020), we refer to the German term Kolluvium, which defines colluvial deposits as the correlate sediments of human-induced soil erosion (e.g., Kadereit et al., 2010). In central Europe, human impact on the terrestrial ecosystem has distinctly increased since the Late Holocene (Winiwarter and Bork, 2019), and land use practices such as deforestation and soil tillage have left land use traces (e.g., charcoal, archaeobotanical and biogeochemical proxies) that are archived in colluvial deposits by impeding degradation processes through continuous sedimentation (Kühn et al., 2017). Therefore, colluvial deposits can be considered one of the key archives for human-land interactions (Pietsch and Kühn, 2017; Zádorová and Penížek, 2018) as they store not only the history of climate and sedimentation, but also proxies for past land use change and associated practices (Dreibrodt et al., 2010a, b; Scherer et al., 2021). These land use proxies can be spatially and temporally related to nearby settlement sites, which allows for a more detailed understanding of local phases of land use. For example, the determination of charcoal assemblages from different colluvial horizons can help to identify changes in woody vegetation that could be the result of anthropogenic efforts to promote a certain type of landscape (Dreibrodt et al., 2009; Schroedter et al., 2013). The vegetation changes could be accompanied by the use of fire, which is reflected in the accumulation of polycyclic aromatic hydrocarbons (PAHs) (Tan et al., 2020). An increased occurrence of open landscapes, as indicated by a higher abundance of grass phytoliths and the determination of charred archaeobotanical remains, provides information on past arable farming and on the nutritional basis of past 
societies (Ball et al., 1999; Rösch, 2013; Weißkopf et al., 2014). The application of manure and/or the keeping of livestock can be considered an integral part of prehistoric land use practices (Bogaard, 2004). The analysis of extracellular urease and faecal biomarker in colluvial horizons helps to identify these land use practices (Borisov and Peters, 2017; Lauer et al., 2014). The distinction between the geogenic background and the additional atmospheric or direct input by anthropogenic contamination in colluvial horizons can be investigated by heavy metal analyses of all horizons, including part of the buried soil profiles, which have no or minor anthropogenic influences (Dreibrodt et al., 2009; Henkner et al., 2018b).

Within the northwestern Alpine foreland, the Hegau (SW Germany) is a suitable study area for the investigation of MBA land use due to the widely distributed occurrence of colluvial deposits and the density of known archaeological sites (Dieckmann, 1998; Höpfer, 2014). Studies on colluvial deposits in the Hegau have shown that local land use activities can be dated back to the Neolithic and still occur in the modern period (Höpfer et al., 2016; Schulte and Stumböck, 2000; Vogt, 2014). Regarding the Bronze Age, Vogt (2014) has documented a regional deposition phase close to Lake Constance, that occurred mainly in the Early Bronze Age (EBA; 2200-1600 BCE). Further inland, Schulte and Stumböck (2000) found only Late Bronze Age (LBA; 1050-800 BCE) to Early Iron Age (EIA; 800-450 BCE) colluvial deposits. However, archaeological remains from the inner Hegau reflect phases of human occupation during the MBA, but corresponding phases of colluvial deposition are far less frequent. Hence, biogeochemical proxies of MBA colluvial deposits for the reconstruction of related land use practices have not been analyzed in this region so far.

To address the question of which land use practices were typical of the MBA in the northwestern Alpine foreland, we applied a multi-proxy approach to colluvial deposits, buried topsoils and archaeological features at the well-documented settlement site of Anselfingen (Anselfingen-Breite, ABR), ca. $20 \mathrm{~km}$ west of Lake Constance. Colluvial deposits, buried topsoils and archaeological features were associated by deciphering the local stratigraphy. Numerical dating, such as the optically stimulated luminescence (OSL) dating of single colluvial horizons and the AMS radiocarbon $\left({ }^{14} \mathrm{C}\right)$ measurements of charcoal fragments, was applied to establish a temporal framework that could be related to local archaeological records. The analyses of the soil micromorphology, phytoliths, charred archaeobotanical remains, urease activity, faecal biomarker, animal bones, PAHs, charcoal assemblages and heavy metals were used to reconstruct past land use practices. The sum of all proxies, which were applied within the settlement (on-site) and at the presumable land use areas (near-site), is used for a better understanding of land use practices related to the human occupation at the Anselfingen site. The investigation of two off-site pollen profiles in this study allowed for a comparison between the local information of land use and vegetation change with the vegetation and land use patterns visible on a regional scale.

Our study focuses on the following:

i. archaeopedological reconstruction of phases of colluvial depositions and on-site and near-site land use practices (e.g., crop cultivation, livestock husbandry, and manuring as well as the use of fire, wood and metal) at the settlement site of Anselfingen through combining the biogeochemical analyses of colluvial deposits and buried topsoils with the analysis of archaeological features;

ii. identification of spatial patterns of on- and near-site land use practices within the Anselfingen settlement and its surrounding area;

iii. characterization of differences and similarities between the on-site and near-site vegetation patterns resulting from land use practices in Anselfingen and the off-site vegetation signals derived from two pollen profiles.

\section{Material and methods}

\subsection{Physical geographical setting}

The study area is in the northwest of the Hegau (SW Germany), which is part of the northwestern Alpine foreland (Fig. 1). In the north, the study area borders the southern decline of the Swabian Jura, from where the tertiary sediments of the Younger Juranagelfluh were transported into the Hegau. The Hegau is characterized by filled volcanic vents (with phonolite, basalt and porphyry) as remains of the tertiary volcanism and is mainly covered by tertiary porphyry (Deckentuff), Würmian glacial and glaciofluvial deposits such as (terminal) moraines and gravel (Schreiner, 2008; Geyer et al., 2011).

Soil substrates in and around the excavation near Anselfingen (Anselfingen-Breite, ABR) are redeposited sediments and weathered bedrock from the Younger Juranagelfluh and the Würmian glaciofluvial deposits (mainly gravel, sand and silt). Volcanic material comes from the Hohenhewen (mainly basalt) in the west of the excavation area. The ABR site lies on glaciofluvial deposits next to the outer young terminal

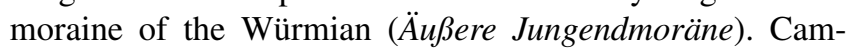
bisols, Luvisols, Phaeozems and Calcaric Regosols, which developed on different substrates and with different stagnic and vertic features, dominate the Reference Soil Groups according to the World Reference Base for Soil Resources (IUSS Working Group WRB, 2015). The climate is moderately warm, with annual average air temperatures between 7.5 and $8.5^{\circ} \mathrm{C}$, whereas the hilltops are between 6 and $7{ }^{\circ} \mathrm{C}$. The annual precipitation is between 700 and $825 \mathrm{~mm}$. The potentially natural vegetation is dominated by central European thermophilous calciphilous beech forests (Fagus sylvatica) with white wood-rush (Luzula luzuloides) and by central European sessile oak (Quercus petraea)-beech forests; 
both are characterized by a rich and diverse shrub and herb layer (Bohn et al., 2003). The modern vegetation is strongly shaped by agricultural and forestry activities.

\subsection{Archaeological setting}

The Hegau is rich in archaeological sites and is particularly important for the Bronze Age research in the northwestern Alpine foreland (Hald and Kramer, 2011). Among the most prominent sites are the large Early Bronze Age (EBA) cemetery of Singen (Krause et al., 1988) and several well-preserved lakeside settlements such as Bodman "Schachen" (Köninger, 2006). However, EBA sites are comparatively scarce further inland, whereas, during the Middle Bronze Age (MBA), there was an increase in settlement activity concentrated mainly on the areas further inland, while the lakeshore sites were almost completely excluded (Höpfer, 2014; Menotti, 2003). From the Late Bronze Age (LBA), numerous burial sites are known, such as the necropolis in Singen (Brestrich, 1988). Additionally, numerous LBA settlements have been documented in the inland, on the lakesides and on the hilltops (Schöbel, 1996; Hopert et al., 1998).

The Anselfingen (Anselfingen-Breite, ABR) settlement (Fig. 2) lies further inland of the Hegau and had occupation phases in the Younger and Final Neolithic, the EBA, MBA and LBA, the Hallstatt and Latène period of the Celtic Iron Age and the Roman period (Ehrle et al., 2018). The adjacent area was densely settled during the MBA, with up to three additional villages, Mühlhausen-Ehingen (Dieckmann, 1998; Hald, 2015), Engen-Welschingen (Hald et al., 2015) and Hilzingen-Binningen (Wissert, 1985), within a distance of $5 \mathrm{~km}$. Since the beginning of the 20th century, the gravel pit has been active, and many archaeological finds have been reported. Until recently, these finds mainly included the remains of a Celtic settlement (Kellner-Depner, 2016). Along with a scattering of Final Neolithic finds, there were also stray finds, which indicated the existence of an MBA burial site (Kraft, 1928; Garscha, 1936). The actual MBA settlement was discovered during rescue excavations, which have been performed by the Cultural Heritage Authority of BadenWürttemberg and the Archaeological Service of the District of Constance since 2008 and continue with the expansion of the gravel pit. To date, almost 9 ha has been excavated, and another 4 ha to the north has been explored by trench prospection.

\subsection{Vegetation history}

Compared to the Lake Constance area, with its lake, peat bogs and wetland depositional environments, the inner Hegau was hardly investigated palynologically until the end of the 20th century (Eusterhues et al., 2002; Hölzer and Hölzer, 1990). Lake Steißlingen remained the most northwestern pollen archive investigated so far, which left the interpretation of vegetation history vague further inland. De- spite the scarceness of potential archives in the inner Hegau, the profiles of Grassee and Hartsee presented here (Fig. 1) are two recently studied pollen profiles that provided nearly complete Late Würmian and Holocene sequences with sufficient pollen preservation.

Around Lake Steißlingen, the vegetation was dominated by mixed birch and pine forests in the Early Holocene (Preboreal, 9600-8700 BCE) before the spread of hazel in the Boreal (8700-7200 BCE). During the Atlanticum (7200$3700 \mathrm{BCE})$, the land was mainly covered by thermophilus deciduous vegetation, with mixed oak forests restricted to drier soil conditions (Lechterbeck, 2001; Rösch, 1987). Before the arrival of the settlers of the Linear Pottery Culture (5500-5000 BCE), those forests, consisting of Quercus, Alnus, Fraxinus, Ulmus and Corylus, were probably dense. Evidence for agricultural activity at Lake Steißlingen cannot be traced back earlier than 4200 BCE (Lechterbeck, 2001) and is in line with the analyzed pollen profiles from the shores of Lake Constance (Rösch, 1987). From the EBA to the beginning of the MBA, indicators for open landscapes, such as herbs and sweet grasses, are more abundant in the pollen spectra of Lake Steißlingen and lakes in the area surrounding Lake Constance. A lower density of mixed oak forests and an increase in micro-charcoal (as proxy for paleo-fire) and non-arboreal pollen (as proxy for open vegetation) seem to further underline human influence on the landscape. During the MBA and LBA, natural succession indicates a weakening of anthropogenic disturbance (Lechterbeck, 2001; Rösch, 1987). Thereafter, phases of natural succession alternate with phases of human-land interaction during the early Latène period (ca. $450 \mathrm{BCE}$ ), the Roman period (ca. 50 BCE-260 CE) and since $550 \mathrm{CE}$ (Lechterbeck, 2001).

\subsection{Fieldwork}

Soil samples were collected in 2017 and 2018. Soil description followed the German guidelines for soil description (Adhoc-AG Boden, 2005) and were classified according to the World Reference Base for Soil Resources (IUSS Working Group WRB, 2015) using the translation software of Eberhardt et al. (2014). Soil horizons that appeared blackishbrown, were homogeneous and mostly rich in organic matter and charcoal fragments and were without other characteristics of soil formation were designated as colluvial horizons (M horizon, Lat. migrare, to migrate). In the area surrounding the ABR settlement, colluvial deposits are widely distributed due to the slopes of the Hohenhewen and the heterogeneous paleo-relief which remained after glacier retreat. After a soil survey, eight locations were chosen for colluvial profiles. Along the profiles, every colluvial horizon was sampled in a continuous column with $5 \mathrm{~cm}$ depth increments. Different samples were collected for the analysis of faecal biomarkers as well as for the investigation of charcoal, microbiological proxies, soil micromorphological features and further pedogenic and soil-biogeochemical proxies. 


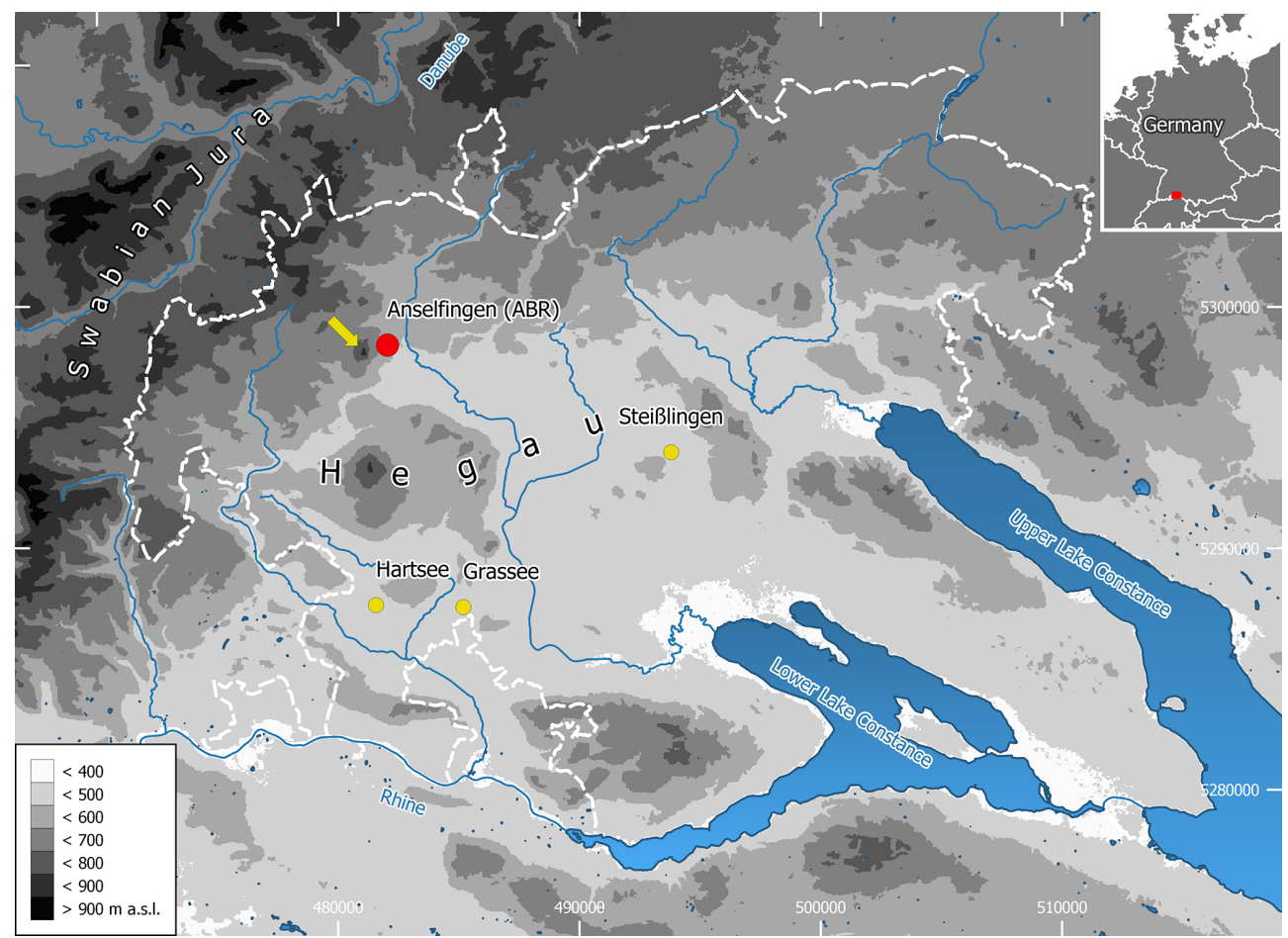

Figure 1. Study area (Hegau, SW Germany) with the Middle Bronze Age settlement site of Anselfingen (ABR, red dot), the pollen profiles (yellow dots) and Hohenhewen (yellow arrow). Coordinates are shown in the UTM 32N reference system; EPSG 25832. Image credits: NASA SRTM-1 V.3 (NASA JPL, NASA Shuttle Radar Topography Mission Combined Image Data Set. NASA EOSDIS Land Processes DAAC (2014); http://doi.org/10.5067/MEaSUREs/SRTM/SRTMIMGM.003, last access: 23 February 2018, (digital terrain model). (C Landesanstalt für Umwelt Baden-Württemberg (2020); https://udo.lubw.baden-wuerttemberg.de, last access: 18 May 2020 (official water management network).

The microbiological samples were cooled during fieldwork and stored at $-18^{\circ} \mathrm{C}$.

Two samples for micromorphology were taken in profile ABR SA2 from $187-197$ and $190-200 \mathrm{~cm}$, which refers to the buried plow horizon 2Apb. Samples for luminescence dating were taken from newly cleaned profile walls with light-proof steel cylinders that were hammered horizontally into the profiles. Bulk samples for dose-rate determination and water content measurements were taken in plastic bags around the sample holes of the cylinders.

During the rescue excavation, the colluvial deposits were removed mechanically until the in situ soil was exposed (Fig. 3). Subsequently, a main planum was made and documented. Archaeological features observed in colluvial horizons were documented in additional plana. All features were further examined in at least one cross section. Documentation comprised analogue and digital photography, standardized text descriptions and digital mapping via theodolite and/or photogrammetry. Spatial data were processed using ArchaeoCAD (ArcTron $\mathrm{GmbH}$ ) during the excavation and transferred to Quantum GIS (long term release 3.10.8 "A Coruña") for analysis. From a series of documented finds, charcoal samples for further AMS ${ }^{14} \mathrm{C}$ measurements were collected, in addition to those already published (Höpfer et al., 2021).

The two cores for the pollen analysis were taken with a modified Livingstone sampler (Merkt and Streif, 1970) from the almost dry surface of Grassee and from a raft at Hartsee. The Grassee mire is divided into two sections by a forest and two forest tracks. The eastern section is dominated by an alder carr, and the western section, from which the core was taken, represents an open fen. The Hartsee mire consists of several small and shallow lakes which are surrounded by wetland. The core was taken from the eastern part. Both profiles were subsampled in close distances; samples for pollen analysis were taken at $2 \mathrm{~cm}$ intervals. The Grassee and Hartsee profile had a length of 700 and $635 \mathrm{~cm}$, respectively.

\subsection{Laboratory analyses}

X-ray granulometry (SediGraph 5120, Micromeritics GmbH, Germany) was used for the determination of grain sizes $<20 \mu \mathrm{m}$, while grain sizes between $20 \mu \mathrm{m}$ and $2 \mathrm{~mm}$ were measured by weighing the sieved soil material. The soil $\mathrm{pH}\left(\mathrm{CaCl}_{2}\right)$ value was analyzed using a soil: solution ratio of $1: 2.5$ (Sentix 81, WTW, pH 340). Carbonate content $\left(\mathrm{CaCO}_{3}\right)$ was volumetrically determined using a calcimeter 


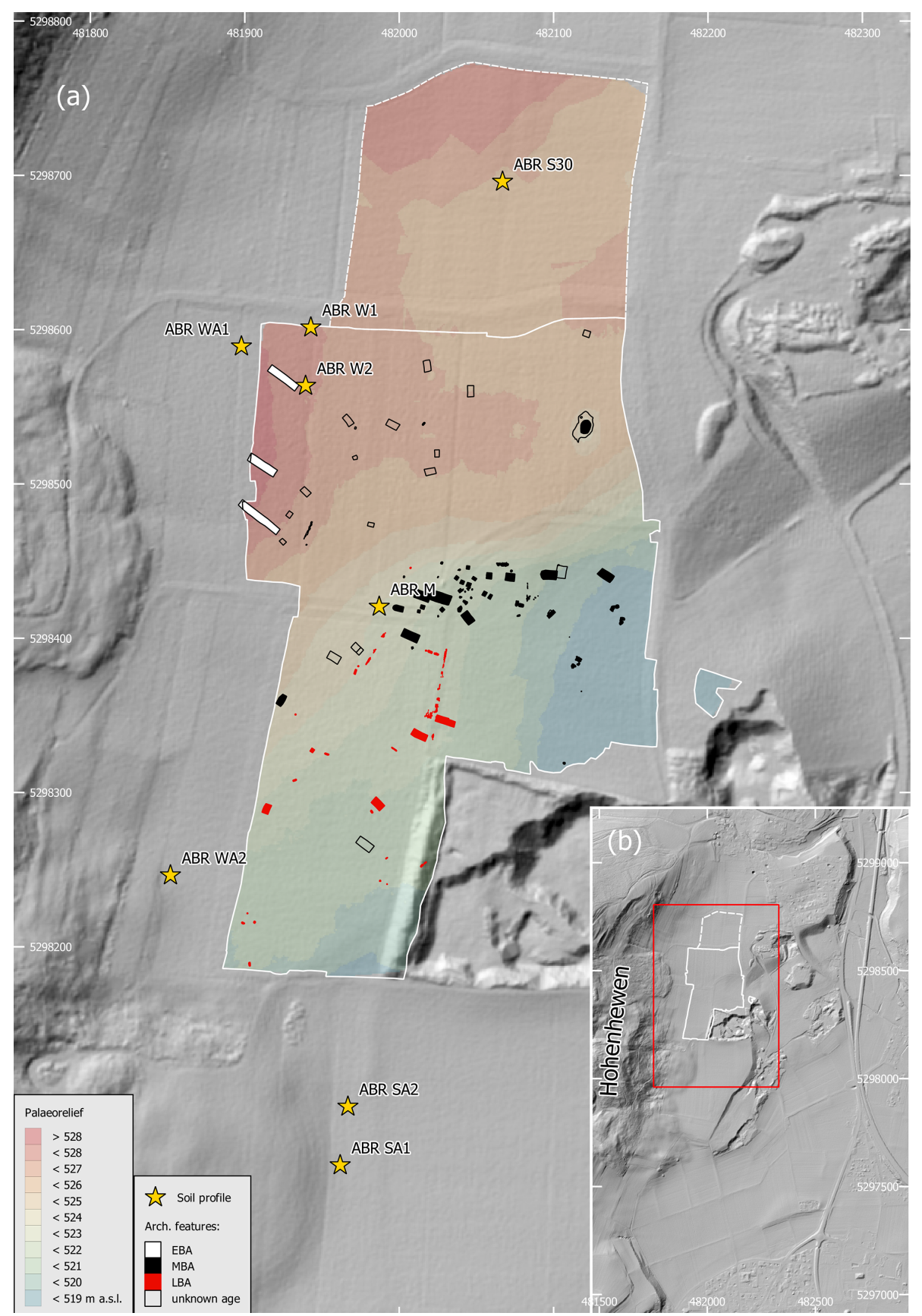

Figure 2. (a) Location of the investigated colluvial deposits and the Bronze Age structures (EBA: Early Bronze Age; MBA: Middle Bronze Age; LBA: Late Bronze Age) and their topographic situation in Anselfingen-Breite (ABR). Colored area shows boundary A according to Edgeworth et al. (2015), i.e., the paleo-surface on which the colluvial deposits accumulated. (b) The excavation area (red frame) and the ascent to the Hohenhewen to the west. Coordinates are shown in the UTM 32N reference system; EPSG 25832. Lidar credits: (C) LGL Baden-Württemberg; https://www.lgl-bw.de, provided on 21 November 2019 (date of recording 2002, resolution $1 \times 1 \mathrm{~m}$ ).

(Eijkelkamp, Giesbeek). An element analyzer (vario EL III, Elementar Analysesysteme GmbH, Germany, in CNS mode) with helium atmosphere and oxidative heat combustion at $1150^{\circ} \mathrm{C}$ was used for the measurement of total carbon (TC) and nitrogen (TN). The difference of total inorganic carbon
(TIC) and TC was used for the calculation of the soil organic carbon (SOC) content (Don et al., 2009).

After air-drying, the oriented samples for soil micromorphology were impregnated with Viscovoss N50S resin and MEKP505F hardener. After the resin had cured, the blocks were first formatted into $60 \times 90 \mathrm{~mm}$ blocks and then cut 
in half with a saw (Woco Top 250 A1, Uniprec). One-half was ground with an encapsulated precision grinding machine (LDQ 6100, Huayid) and mounted on a glass. After $3 \mathrm{~d}$ the mounted samples were cut into about $100 \mu \mathrm{m}$ thick slices and then ground to $30 \mu \mathrm{m}$. Thin sections were described under a polarizing microscope (Zeiss Axio Imager.A2m; Software AxioVision 4.7.2), mainly using the terminology of Stoops (2003).

All samples for OSL dating were analyzed using the coarse grain quartz fraction with a grain size range of 90-200 $\mu \mathrm{m}$. The paleodose $\left(D_{e}\right)$ determination was conducted using a standard SAR protocol following Murray and Wintle (2000, 2003). Radionuclide concentrations were determined either via a combination of thick source alphacounting (for $\mathrm{U}$ and $\mathrm{Th}$ ) and ICP-OES (for $\mathrm{K}$ ) or via a combination of alpha- and beta-counting in a $\mu$ Dose system (Tudyka et al., 2020).

Charcoal fragments from the colluvial profiles and archaeological features were dated with $\mathrm{AMS}{ }^{14} \mathrm{C}$ dating at the Klaus Tschira Lab at the Curt Engelhorn Centre of Archaeometry in Mannheim. The acid-base-acid method was conducted for sample pre-treatment (Steinhof et al., 2017). The ${ }^{14} \mathrm{C}$ ages were normalized to $\delta^{13} \mathrm{C}=-25 \%$ (Stuiver and Polach, 1977). The calibration of ${ }^{14} \mathrm{C}$ ages to calendar years was performed with SwissCal 1.0 using the IntCal13 calibration curve (Ramsey, 2009; Reimer et al., 2013).

For the determination of charcoals, 529 fragments from three colluvial profiles (ABR W2: 267, ABR SA1: 120, ABR SA2: 162) were retrieved by flotation. The transversal, tangential and radial sections of charcoal were investigated for diagnostic features, using magnifications between $60 \times$ and $500 \times$. Identification literature (Schweingruber, 1990a, b) was consulted, as well as the charcoal reference collection of the Archaeobotany Laboratory at University of Tübingen.

The extraction of phytoliths was conducted at the universities of Würzburg and Tübingen and followed the procedures outlined by Albert et al. (1999) and Katz et al. (2010), respectively. Morphological identification of the phytoliths followed the standard literature (Brown, 1984; Piperno, 2006; Twiss et al., 1969) and modern plant reference collections (Albert, 1999; Portillo et al., 2014; Tsartsidou et al., 2007). The International Code for Phytolith Nomenclature was followed where possible (Madella et al., 2005). Phytolith morphologies are grouped into three main categories: herbaceous dicotyledonous plants, woody dicotyledonous plants and monocotyledonous plants (Piperno, 2006).

For the archaeobotanical investigation, a total of 20 samples from MBA structures (e.g., fire pits with heat stones, fireplaces, deposited vessels and post-holes from architectural remains) were analyzed. The sediment samples were washed over a multi-part sieve set. The smaller fractions were floated to separate the organic components from the mineral ones. The $0.3 \mathrm{~mm}$ fractions of three charcoal-rich samples could only be examined for $10 \%$ to $30 \%$. All other samples and fractions that were screened completely under the binocular and botanical macro remains, excluding charcoal, were taken out. The determination was carried out following the current literature (Jacomet, 1987; Jacomet et al., 1989; Bekker and Cappers, 2006) and the reference collection of the Laboratory for Archaeobotany in Hemmenhofen.

For the analysis of polycyclic aromatic hydrocarbons (PAHs), a modified protocol of Bläsing et al. (2016) was followed. A speed extractor (E-916, Büchi Labortechnik $\mathrm{GmbH}$, Germany) was used for sample extraction; samples were concentrated using Rotavapor (Büchi, Switzerland). Solid phase extraction (SPE) was used for sample purification according to Lehndorff and Schwark (2009). The quantification of PAHs was performed using gas chromatography (GC; Agilent Technologies 7890B, Germany) coupled with mass spectrometry (MS/MS; EVO 3, Chromtech, Germany).

The extracellular enzyme urease is responsible for the cleavage of urea to ammonia and $\mathrm{CO}_{2}$, and its microbial production is stimulated by the presence of eutrophic soil conditions (e.g., faeces of animals) (Kandeler and Gerber, 1988). Its specific feature is that urease-organo-mineral complexes are stable for long time periods (Skujiòs and McLaren, 1968). Extracellular urease activity derived from soil organisms was determined colorimetrically according to Kandeler and Gerber (1988). Synergy HTX multi-mode reader (BioTek) was used for colorimetric measurements at $690 \mathrm{~nm}$.

Microbial biomass carbon $\left(\mathrm{C}_{\text {mic }}\right)$ was determined by the substrate-induced respiration method (SIR) (Anderson and Domsch, 1978). Measurements were taken using an automated respirometer system based on electrolytic $\mathrm{O}_{2}$ microcompensation (Scheu, 1992). A detailed description of sample preparation and data analysis is given in Scherer et al. (2020). In this study, the urease activity was related to the microbial biomass carbon to differentiate between past and present input of urea, since extracellular urease is considered to be very stable and $\mathrm{C}_{\mathrm{mic}}$ as a proxy for current microbial activity. Increased urease activities to microbial biomass ratios are therefore an indicator for ancient soil eutrophication by animal faeces.

Faecal biomarkers (sterols, stanols, stanones) were analyzed using a modified protocol according to Prost et al. (2017) and Birk et al. (2012). A speed extractor (E-916, Büchi Labortechnik GmbH, Germany) was used for accelerated sample extraction. For the analysis of sterols, stanols and stanones, the total lipid extracts (TLEs) were analyzed using gas chromatography (GC; Agilent Technologies 7890B, Germany) coupled with mass spectrometry (MS/MS; EVO 3, Chromtech, Germany). For detailed information about sample preparation, equipment and hardware settings, see Scherer et al. (2020).

A reverse aqua regia solution $\left(\mathrm{HNO}_{3}\right.$ to $\mathrm{HCl}$ ratio $1: 3$, DIN ISO 11466: 1997-2006) in a microwave (MLS GmbH, Germany) was used for the dissolutions of the heavy metals (As, Cd, Cr, Cu, Hg, Ni, Pb, Zn). ICP-OES (Optima 5300DV, Perkin Elmer Inc.) equipped with a Miramist nebulizer using 
the element-specific wavelengths according to Nölte (2002) was used for the measurements of heavy metal contents.

The taxonomic and taphonomic analysis of bone material was carried out in the zooarchaeological comparative collection of the University of Tübingen. The faunal age was assessed and classified according to Lyman (1994). The taphonomic analysis comprised natural and anthropogenic impacts on the bones such as burning, animal bites, human cutmarks and traces of natural environmental influences as root etching, changes due to sunlight or weathering. Burned bones were categorized in six categories following Stiner (1995). A detailed description of the methodological approach is given in Scherer et al. (2020).

The investigation of the pollen profiles was focused on the Bronze Age period (2200-800 BCE) and was composed of 17 pollen samples at the Grassee and 59 pollen samples from the Hartsee mire. The time resolution was 70 years for the Grassee and 20 years for the Hartsee mire. The chemical preparation for pollen analyses was carried out using hot $\mathrm{HCl}, \mathrm{HF}$, chlorination, and acetolysis (Berglund, 1986). The material was stored in glycerol. For the analysis, permanent unstained glycerol slides were used.

Detailed information on sample preparation, equipment and data presentation for each method can be found in Scherer et al. (2020).

\section{Results}

\subsection{Stratigraphy and related pedofeatures}

Eight multi-layered colluvial profiles were documented with a thickness of at least $200 \mathrm{~cm}$ (Table 1). The colluvial horizons of ABR S30, ABR W1, ABR W2, ABR WA1 and ABR M developed mostly from the sediments of the Younger Juranagelfluh and buried fully preserved or truncated (vertic) Cambisols, which developed in loamy glaciofluvial sediments with different proportions of gravels. In profiles ABR W1, ABR W2 and ABR WA1, paleo-land surfaces were characterized by blackish horizons with a well-developed prismatic and angular blocky structure with slickensides. An excavation boundary of about $150 \mathrm{~m}$ stratigraphically connects profiles ABR W1, ABR W2 and ABR WA1 and the paleo-surface, which contained the archaeological finds. The thickness of colluvial deposits along the excavation wall decreased from north to south (Fig. 3). For ABR M and ABR S30, a higher percentage of calcareous gravel was observed. The soil substrates of profiles ABR WA2, ABR SA1 and ABR SA2 were mostly derived from basaltic material from the Hohenhewen volcano. For profile ABR SA2, a buried plow horizon (2Apb) with a sharp transition to the underlying subsoil horizon $(2 \mathrm{CBw})$ was observed. For all profiles, the transition between colluvial deposit and paleo-surface (boundary A according to Edgeworth et al., 2015), i.e., the prehistoric surface, was documented.
For all colluvial profiles, a high clay content between $32 \%$ and $65 \%$, with a sharp (ABR W1, ABR W2) to moderate (ABR SA2) increasing trend with depth, was determined. The maximum clay contents $(>60 \%)$ were measured in the buried subsoil horizons (2Bwig) of ABR W1 and ABR W2. The sand fraction decreased with depth (up to $17 \%$ difference) for profiles ABR W1 and ABR W2, whereas for ABR SA2, differences of only $7 \%$ were determined. The silt proportions were the highest at the present topsoil horizons and ranged between $25 \%$ and $48 \%$. The soil $\mathrm{pH}$ of all soil profiles showed a neutral soil milieu and no tendency in depth, with values between 7.1 and 7.8 (mean: 7.4, SD: 0.1, $n: 75$ ). The content of $\mathrm{CaCO}_{3}$ ranged between $1 \%$ and $32 \%$ (mean: 11.1, SD: 9.6, $n: 75)$ for all profiles, with decreasing values in greater soil depth. The less weathered or unweathered glacial and glaciofluvial sediments (all 2C horizons) showed less evidence of decalcification. The SOC contents were between $0.1 \%$ and $3.1 \%$ (mean: 0.9 , SD: $0.5, n: 75$ ), and for all profiles the maximum values were found in the present and buried topsoil and in the deepest colluvial horizons. The carbon to nitrogen ratio $(\mathrm{C} / \mathrm{N})$ mimicked the depth gradients of SOC, showing narrower ratios at lower carbon states. In total, the ratio varied between 5 and 12 (mean: 7.8, SD: 3.0, $n: 75)$ (Table 1).

\subsection{Dating}

All measurements revealed bright and fast decaying luminescence signals indicative of quartz with a dominant fast component. At least 19 aliquots were measured per sample, and the resulting $D_{e}$ distributions were analyzed with respect to their overdispersion, kurtosis and skewness (Bailey and Arnold, 2006). The samples GI520-GI531 (ABR W1 and ABR W2), GI743 (ABR SA2), GI 786 and GI788 (both ABR $\mathrm{M})$ showed narrow and symmetric $D_{e}$ distributions, typical of complete bleaching, whereas all other samples (mainly from ABR SA1 and ABR M) displayed strong indications for incomplete bleaching through positively skewed and overdispersed $D_{e}$ distributions (see Fig. S1). For well bleached samples, the mean $D_{e}$ was calculated using the central age model (Galbraith et al., 1999), and for incompletely bleached samples, a bootstrap minimum age model (Galbraith et al., 1999; Cunningham and Wallinga, 2012) was applied. A sigma b value of $0.12-0.15$ was used in this model, according to the lowest overdispersion of a well bleached sample from the same profile. Resulting ages are in correct chronostratigraphic order and are summarized in Fig. 4 (see also Scherer et al., 2020), along with $D_{e}$ values and the underlying age model.

The AMS ${ }^{14} \mathrm{C}$ ages showed a correct chronological trend, and only a few minor age reversals occurred on a $2 \sigma$ significance level (Fig. 4; see also Scherer et al., 2020). The comparison of OSL and ${ }^{14} \mathrm{C}$ ages at the same sampling depth mostly showed older radiocarbon ages in younger dated sedi- 
Table 1. Pedological data of selected profiles (units are given as mass in \%). n.a.: not analyzed, LoD: limit of detection. Soils according to US Soil Taxonomy (family level): Dystrudepts.

\begin{tabular}{lrrrrrr}
\hline Horizon & Depth [cm] & $\mathrm{CaCO}_{3}[\%]$ & $\mathrm{pH}\left[\mathrm{CaCl}_{2}\right]$ & Clay, silt, sand [\%] & SOC [\%] & $\mathrm{C} / \mathrm{N}$ \\
\hline \multicolumn{1}{l}{ ABR W1: Calcaric Cambisol } & Endoclayic, Pantocolluvic, Epiloamic, Ochric, Epiraptic) & \\
\hline Ap & $0-10$ & 28 & 7.6 & $32,47,21$ & 0.5 & 6 \\
M1 & $10-50$ & 26 & 7.6 & $36,45,19$ & 0.4 & 5 \\
M2 & $50-105$ & 20 & 7.6 & $40,43,17$ & 0.3 & 5 \\
M3 & $105-153$ & 10 & 7.6 & $48,40,12$ & 0.5 & 6 \\
M4 & $153-180$ & 2 & 7.6 & $53,37,10$ & 0.9 & 9 \\
M5 & $180-206$ & 1 & 7.4 & $52,38,10$ & 1.0 & 10 \\
M6 & $206-215$ & 1 & 7.4 & $50,39,11$ & 1.2 & 11 \\
2Bwig/2Ahb & $215-235$ & 1 & 7.3 & $50,40,10$ & 1.4 & 12 \\
2Bwig & $235-282+$ & 1 & 7.3 & $65,31,4$ & 0.5 & 7
\end{tabular}

ABR W2: Calcaric Pantocolluvic Regosol (Acric, Pantoclayic, Ochric, Endoraptic)

\begin{tabular}{lrrrrrr}
\hline Ap & $0-30$ & 27 & 7.4 & $34,48,18$ & 1.1 & 7 \\
M1 & $30-82$ & 29 & 7.5 & $34,44,22$ & 0.2 & $<$ LoD \\
M2 & $82-98$ & 28 & 7.5 & $35,44,21$ & 0.1 & $<$ LoD \\
M3 & $98-155$ & 15 & 7.5 & $46,39,15$ & 0.5 & 6 \\
M4 & $155-170$ & 4 & 7.6 & $54,36,10$ & 1.0 & 8 \\
M5 & $170-185$ & 2 & 7.5 & $54,34,12$ & 1.1 & 9 \\
M6 & $185-215$ & 1 & 7.4 & $57,35,8$ & 1.6 & 11 \\
2Bwig/2Ahb & $215-230$ & 1 & 7.4 & $59,35,7$ & 1.7 & 11 \\
2Bwig & $230-262$ & 1 & 7.3 & $62,33,6$ & 0.9 & 8 \\
2CBg & $262-290+$ & 17 & 7.6 & $45,38,16$ & 0.3 & $<$ LoD \\
\hline
\end{tabular}

ABR WA1: Calcaric Pantocolluvic Regosol (Acric, Anoloamic, Ochric, Amphiraptic, Bathyclayic)

\begin{tabular}{lrrrrrr}
\hline Ap & $0-25$ & 31 & 7.1 & n.a. & 0.9 & 6 \\
M1 & $25-52$ & 30 & 7.4 & n.a. & 0.3 & $<$ LoD \\
M2 & $52-94$ & 27 & 7.4 & n.a. & 0.2 & $<$ LoD \\
M3 & $94-130$ & 23 & 7.5 & n.a. & 0.2 & $<$ LoD \\
M4 & $130-163$ & 20 & 7.5 & n.a. & 0.5 & 6 \\
M5 & $163-200$ & 10 & 7.4 & n.a. & 0.8 & 7 \\
M6 & $200-220$ & 6 & 7.4 & n.a. & 1.0 & 9 \\
2Bwig/2Ahb & $220-260$ & 2 & 7.3 & n.a. & 1.3 & 10 \\
2Bwig & $260-275$ & 8 & 7.4 & n.a. & 0.7 & 5 \\
2CBg & $275-290+$ & 21 & 7.4 & n.a. & 0.1 & $<$ LoD \\
\hline ABR WA2: Calcaric Cambisol (Pantocolluvic, Humic, Anoloamic, Bathyclayic) & & \\
\hline Ah & $0-20$ & 11 & 7.3 & n.a. & 2.4 & 8 \\
M1 & $20-64$ & 14 & 7.3 & n.a. & 0.9 & 6 \\
M2 & $64-95$ & 11 & 7.4 & n.a. & 0.8 & 8 \\
M3 & $95-124$ & 7 & 7.4 & n.a. & 0.9 & 7 \\
M4 & $124-150$ & 11 & 7.4 & n.a. & 0.7 & 7 \\
M5 & $150-190$ & 6 & 7.5 & n.a. & 0.9 & 8 \\
M6 & $190-205$ & 6 & 7.5 & n.a. & 1.0 & 9 \\
M7 & $205-225$ & 2 & 7.5 & n.a. & 1.3 & 10 \\
2Bwg & $225-250+$ & 1 & 7.4 & n.a. & 1.1 & 9 \\
\hline
\end{tabular}


Table 1. Continued.

\begin{tabular}{|c|c|c|c|c|c|c|}
\hline Horizon & Depth $[\mathrm{cm}]$ & $\mathrm{CaCO}_{3}[\%]$ & $\mathrm{pH}\left[\mathrm{CaCl}_{2}\right]$ & Clay, silt, sand [\%] & $\mathrm{SOC}[\%]$ & $\mathrm{C} / \mathrm{N}$ \\
\hline \multicolumn{7}{|c|}{ ABR SA1: Calcaric Cambic Phaeozem (Acric, Anoclayic, Pantocolluvic, Bathyloamic) } \\
\hline Ah & $0-20$ & 14 & 7.2 & n.a. & 2.2 & 9 \\
\hline M1 & $20-33$ & 15 & 7.3 & n.a. & 1.6 & 8 \\
\hline M2 & $33-50$ & 15 & 7.4 & n.a. & 0.9 & 8 \\
\hline M3 & $50-63$ & 16 & 7.4 & n.a. & 0.7 & 8 \\
\hline M4 & $63-75$ & 13 & 7.4 & n.a. & 0.7 & 7 \\
\hline M5 & $75-88$ & 6 & 7.5 & n.a. & 0.9 & 8 \\
\hline M6 & $88-100$ & 2 & 7.5 & n.a. & 1.1 & 9 \\
\hline M7 & $100-128$ & 1 & 7.3 & n.a. & 1.2 & 9 \\
\hline $2 \mathrm{Bw}$ & $128-145$ & 1 & 7.3 & n.a. & 0.9 & 8 \\
\hline $2 \mathrm{CBw}$ & $145-200+$ & 17 & 7.4 & n.a. & 0.6 & 6 \\
\hline \multicolumn{7}{|c|}{ ABR SA2: Calcaric Pantocolluvic Regosol (Acric, Anoclayic, Humic, Endoraptic, Bathyloamic) } \\
\hline $\mathrm{Ah}$ & $0-27$ & 11 & 7.3 & $47,31,22$ & 2.1 & 8 \\
\hline M1 & $27-40$ & 10 & 7.3 & $52,32,26$ & 1.2 & 7 \\
\hline M2 & $40-66$ & 10 & 7.4 & $51,31,26$ & 0.8 & 7 \\
\hline M3 & $66-80$ & 9 & 7.4 & $45,28,27$ & 0.8 & 7 \\
\hline M4 & $80-95$ & 11 & 7.4 & $43,29,28$ & 0.8 & 7 \\
\hline M5 & $95-123$ & 8 & 7.4 & $45,28,27$ & 0.9 & 8 \\
\hline M6 & $123-150$ & 8 & 7.4 & $43,27,28$ & 0.8 & 8 \\
\hline M7 & $150-172$ & 6 & 7.4 & $42,29,29$ & 0.8 & 8 \\
\hline $2 \mathrm{Apb}$ & $172-190$ & 2 & 7.2 & $42,31,27$ & 0.6 & 7 \\
\hline $2 \mathrm{Bw}$ & $190-215+$ & 1 & 7.2 & $51,25,24$ & 0.5 & 6 \\
\hline \multicolumn{7}{|c|}{ ABR S30: Hypereutric Epicalcaric Cambisol (Pantocolluvic, Pantoloamic, Ochric) } \\
\hline Ap & $0-13$ & 11 & 7.6 & n.a. & 1.5 & 8 \\
\hline M1 & $13-45$ & 11 & 7.6 & n.a. & 0.6 & 7 \\
\hline M2 & $45-72$ & 3 & 7.6 & n.a. & 0.7 & 8 \\
\hline M3 & $72-90$ & 1 & 7.5 & n.a. & 0.8 & 8 \\
\hline M4 & $90-140$ & 1 & 7.5 & n.a. & 0.8 & 8 \\
\hline M5 & $140-150$ & 1 & 7.4 & n.a. & 0.7 & 8 \\
\hline 2Bwg & $150-212$ & 3 & 7.3 & n.a. & 0.4 & 5 \\
\hline $2 \mathrm{CBg}$ & $212-240+$ & 25 & 7.8 & n.a. & 0.2 & $<\mathrm{LoD}$ \\
\hline \multicolumn{7}{|c|}{$\begin{array}{l}\text { ABR M: Hypereutric Epicalcaric Endoskeletic Cambisol (Pantocolluvic, Humic, } \\
\text { Anoloamic, Amphiraptic, Bathyclayic) }\end{array}$} \\
\hline Ap & $0-10$ & 22 & 7.3 & n.a. & 3.1 & 9 \\
\hline Ap2 & $10-20$ & 23 & 7.5 & n.a. & 1.5 & 7 \\
\hline M1 & $20-50$ & 28 & 7.6 & n.a. & 0.9 & 7 \\
\hline M2 & $50-90$ & 22 & 7.7 & n.a. & 0.4 & 4 \\
\hline M3 & $90-110$ & 1 & 7.5 & n.a. & 0.9 & 8 \\
\hline 2Bwg/2Ahb & $110-140$ & 1 & 7.4 & n.a. & 0.8 & 10 \\
\hline 2Bwig & $140-160$ & 1 & 7.4 & n.a. & 0.5 & 7 \\
\hline $2 \mathrm{CBg}$ & $160-212$ & 10 & 7.6 & n.a. & 0.2 & 6 \\
\hline $2 \mathrm{Cg}$ & $212-244+$ & 32 & 7.8 & n.a. & 0.1 & $<\mathrm{LoD}$ \\
\hline
\end{tabular}




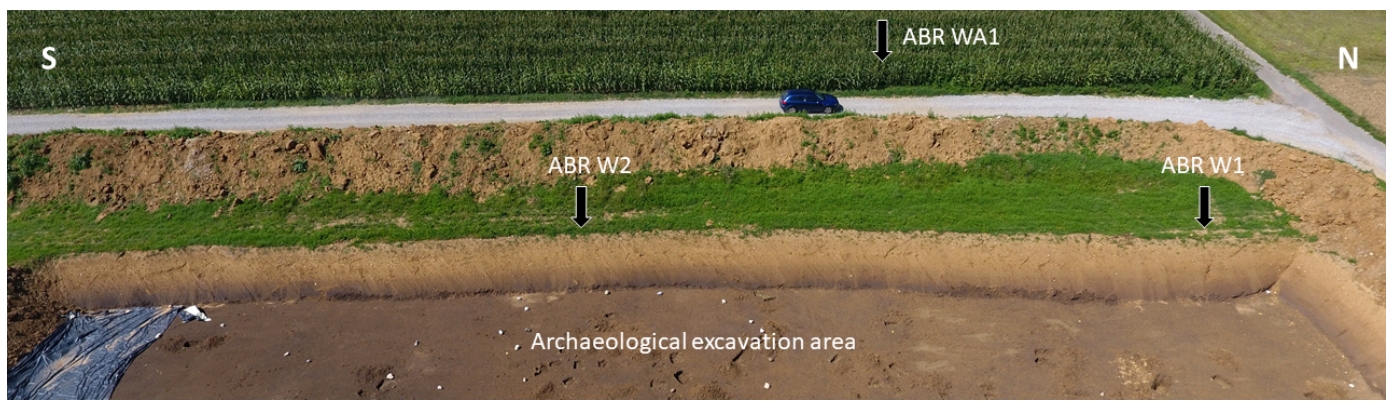

Figure 3. Overview of the western excavation boundary at the ABR site with the colluvial profiles ABR W1, ABR W2 and ABR WA1 and related colluvial horizons $(M)$. Photo: Höpfer (2017). The distance between ABR W1 and ABR W2 is about $38 \mathrm{~m}$.

ments (especially ABR W1 and ABR W2). The overall range of ${ }^{14} \mathrm{C}$ and OSL ages was narrower at the profile ABR SA2.

\subsection{Archaeology}

The majority of MBA finds was observed in the central part of the excavation (Fig. 2, Höpfer et al., 2021). Most MBA features were from wooden architecture, especially in the form of several hundred post-holes. At least 20 buildings, of mostly rectangular shapes but varying sizes and layouts, could be reconstructed (Fig. 5). A total of 10 buildings were reconstructed with smaller areas (ca. 3-7 $\mathrm{m}^{2}$ ) and square or short rectangular shapes (Fig. 5j-t). These were grouped around the presumed MBA settlement center. A small kiln was observed, while a small pit to the north contained a $2 \mathrm{~kg}$ fragment of a copper ingot. Several shallow pits and stone clusters filled with heat stones were grouped around the presumed settlement center. Up to ca. $50 \mathrm{~m}$ southeast of these domestic structures, several ceramic pots and larger fire pits with heat stones were found. The ceramic pots were apparently set into the ground and sometimes contained heat stones. Several wagon tracks and linear discoloration or stone clusters were documented, albeit of mostly uncertain age. North of the settlement, a small kettle hole with a stone plaster was described. The pottery from these features has its biggest similarities with inventories from the later MBA (ca. 1450-1300 BCE). Among the characteristic elements are thick flattened rims on short and steep vessel mouths, raw slurried surfaces, lobes on the body and rim of larger pots and the occasional notched decoration on finer pottery (Krumland, 1998; Rigert et al., 2001; Honig, 2008).

\subsection{Archaeobotanical proxies}

In total, 555 charcoal fragments were collected from the colluvial profiles ABR W2, ABR SA1 and ABR SA2. Although ca. $1.5 \mathrm{~m}$ of ABR W2 was not sampled for charcoal determination, the charcoal output of more than $1 \mathrm{~mm}$ was the highest compared to the other two profiles (50\%). Of the charcoal fragments, $29 \%$ were collected from the ABR SA2 profile and $21 \%$ from ABR SA1. Amongst the charcoal proportions from ABR W2, between a depth of 141 and $262 \mathrm{~cm}$, there was only dicotyledonous woods. Quercus sp. was strongly represented throughout this depth. Fagus sp. could be identified in the horizons M4 to M6 $(165-200 \mathrm{~cm})$. Additionally, a few Fraxinus sp. fragments were found in the horizon M6 (200-215 cm) (Fig. 6a). The charcoal spectra of ABR SA1 showed the following trend: from horizon M7 onwards $(110 \mathrm{~cm})$, only dicotyledons were present, amongst which Quercus sp. was strongly represented. Charcoal fragments of Quercus sp. were not found in a soil depth lower than $73 \mathrm{~cm}$, whereas Fagus sp. occurred in the horizons Ap to M4 (0$73 \mathrm{~cm}$ ) only. From the modern surface to $85 \mathrm{~cm}$ (Ap-M5), conifers appear, some of which could be identified as Pinus sp. (Fig. 6b). A considerable number of charcoal fragments from ABR SA2 could not be determined in detail because they were too small but are attributed as dicotyledonous. In horizon M6 (133-138 cm), Quercus and Fagus sp. dominated the charcoal spectra. In horizons M3 to M5, single fragments were allocated to Pinus sp., Quercus sp., Prunus sp. and conifer wood in general, whereas the majority were determined as dicotyledonous only. In horizons Ap, M1 and M2 similar amounts of conifer (Pinus sp., Abies sp.) and deciduous species (Quercus sp., Fagus sp., Populus/Salix sp.) were identified (Fig. 6c).

Phytoliths were found in all investigated samples of profiles ABR W1, ABR W2 and ABR SA2 (Table 2). The absolute phytolith concentrations of profile ABR W1 were not comparable with those of ABR W2 and ABR SA2 due to different analytical approaches. However, a relative comparison of the phytolith concentrations and different morphotypes and their anatomical origin was possible.

The phytolith concentrations showed an increasing trend with depth for all investigated profiles. The highest values were found in the buried topsoil horizons (2Bwig/2Ahb; $2 \mathrm{Apb}$ ) and the lowest values in the present topsoil and buried subsoil horizons. The morphological analysis revealed that all profiles were similar in their morphotype assemblages. Monocotyledonous morphotypes were the most common group identified. At all profiles, $68 \%$ (SD: $14.0 \%, n: 24$ ) of the phytoliths were assigned to grasses, whereas $16 \%$ 

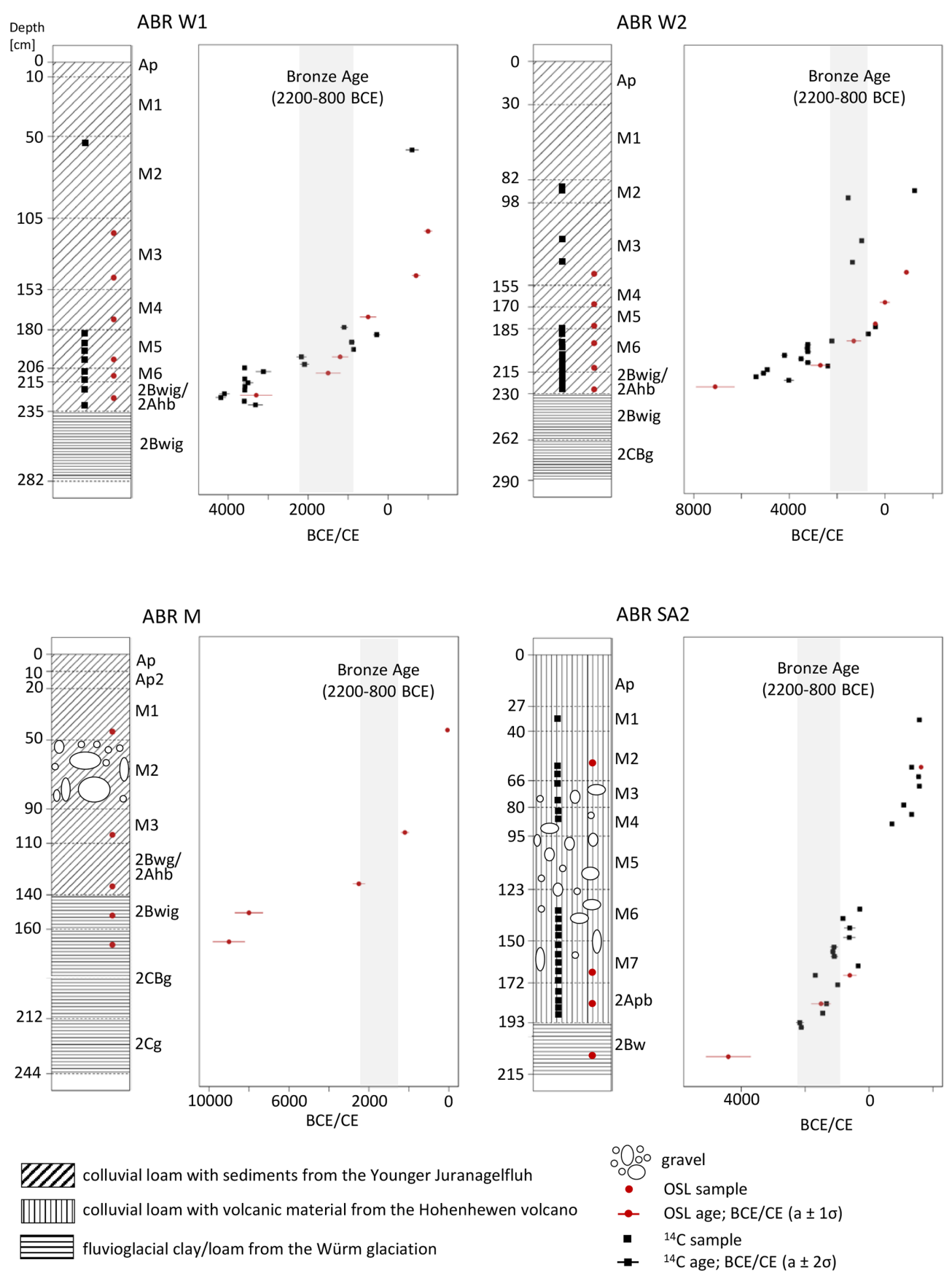

Figure 4. Colluvial profiles used for OSL and ${ }^{14} \mathrm{C}$ dating. Colluvial horizons are designated as $M$.

(SD: $10.0 \%, n: 24)$ were determined as dicotyledonous morphotypes. On average, $15 \%$ (SD: $10.8, n: 24$ ) of the phytoliths appeared to be weathered, so that a morphological or anatomical identification was not possible. Moreover, grass phytoliths were divided into the different anatomical plant parts in which they were formed. At all profiles, short-cell morphotypes, commonly produced in leaves and stems, occurred at different rates, ranging from $9 \%$ to $50 \%$ (mean: $30 \%$, SD: $9.3 \%, n: 24)$. The majority of short cells recov- ered from these samples were those associated with the $\mathrm{C}_{3}$ Pooideae subfamily, to which cereals also belong (e.g., rondels). Grass phytoliths derived from their floral parts ranged between $0 \%$ and $26 \%$ (mean: $6 \%$, SD: $6.5, n: 24$ ), while higher proportions were identified in the samples of ABR W1 (mean: $13 \%$, SD: 6.0, $n$ : 9). Phytoliths stemming from the inflorescence plant parts were minor in the samples of ABR W2 (mean: $2 \%$, SD: $1.6, n: 8$ ) and ABR SA2 (mean: $3 \%$, SD: $1.9, n: 6)$. Epidermal cells from grass leaves and 

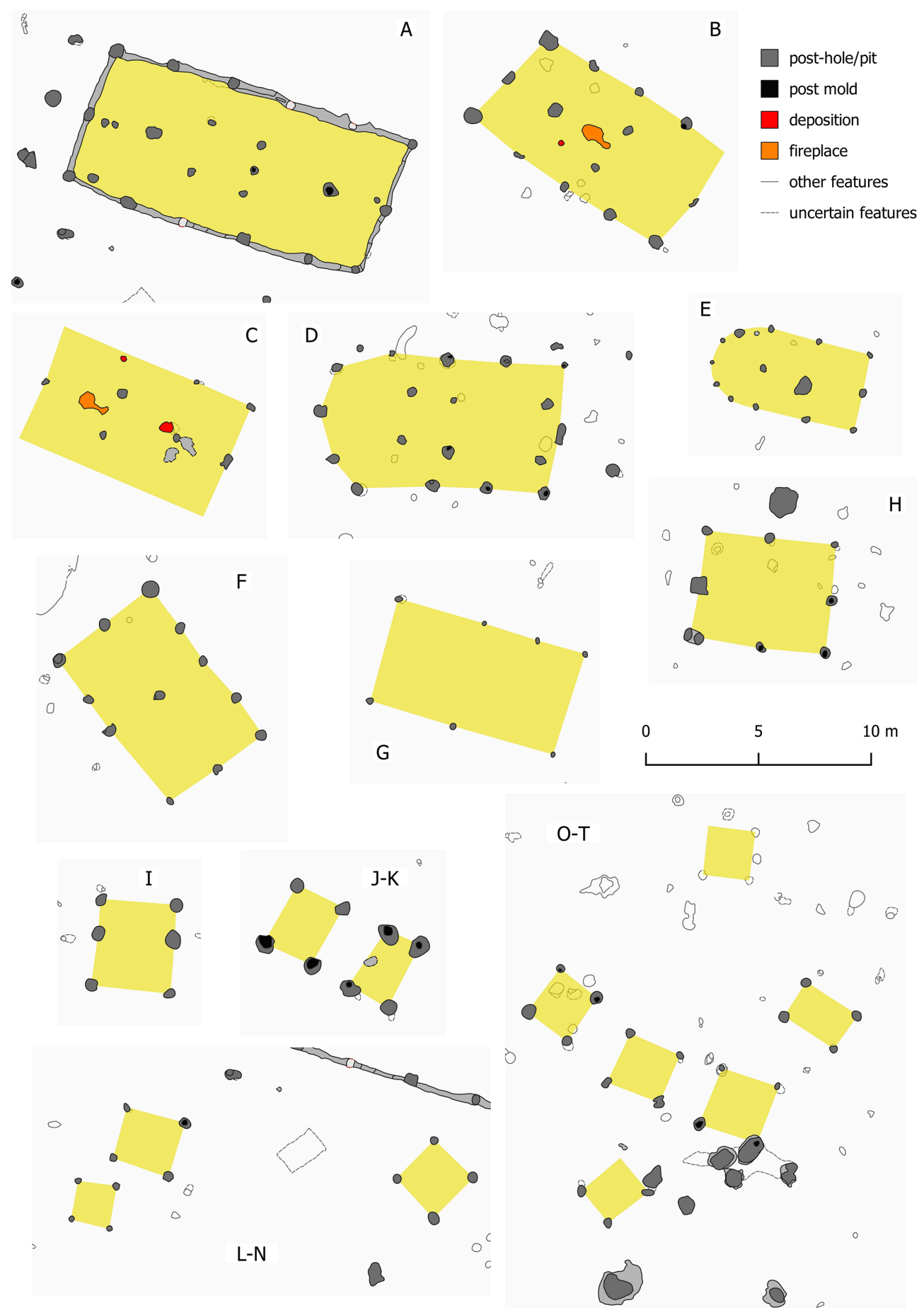

Figure 5. House floor plans of the Middle Bronze Age (MBA) at the Anselfingen excavation.

stems were observed, with an average amount of $63 \%$ (SD: $12.8 \%, n: 24)$.

In total, 163 charred archaeobotanical remains were found in different archaeological features of the ABR site (Fig. 7). They were recovered through wash-over flotation from ca. $150 \mathrm{~L}$ of sediment and reached a concentration of ca. one plant macro remain per liter. The majority of these finds comprises chaff and grains of cereals like barley (Hordeum distichon/vulgare), emmer (Triticum dicoccum), einkorn (Triticum monococcum), spelt (Triticum spelta) and free threshing wheat (Triticum aestivum/turgidum) and occurs mostly in fire pits and architectural remains. The chaff 
$M 3,141-146 \mathrm{~cm}, \mathrm{n}=5$ M3, 146-151 cm, $\mathrm{n}=13$ $M 3,151-155 \mathrm{~cm}, \mathrm{n}=2$ M4, $155-160 \mathrm{~cm}, \mathrm{n}=3$ M4, $165-170 \mathrm{~cm}, \mathrm{n}=5$ M5, $170-175 \mathrm{~cm}, \mathrm{n}=7$ M5, $180-185 \mathrm{~cm}, \mathrm{n}=4$ $M 6,185-190 \mathrm{~cm}, \mathrm{n}=13$ M6, 190-195 cm, $\mathrm{n}=12$ M6, $195-200 \mathrm{~cm}, \mathrm{n}=14$ M6, 200-205 cm, $\mathrm{n}=50$ $\mathrm{M} 6,205-210 \mathrm{~cm}, \mathrm{n}=35$ $M 6,210-215 \mathrm{~cm}, \mathrm{n}=43$ 2Bwig/2Ahb, 215-220 cm, $\mathrm{n}=16$ 2Bwig/2Ahb, 220-225 cm, n=22 2Bwig/2Ahb, $225-230 \mathrm{~cm}, \mathrm{n}=24$ 2Bwig/2Ahb, 235-240 cm, $\mathrm{n}=6$ 2Bwig/2Ahb, 240-262 cm, $n=3$

$$
0
$$

Ap, $0-20 \mathrm{~cm}, \mathrm{n}=2$ M1, 20-25 cm, $\mathrm{n}=3$ $\mathrm{M} 1,25-33 \mathrm{~cm}, \mathrm{n}=2$ $\mathrm{M} 2,40-45 \mathrm{~cm}, \mathrm{n}=3$ $\mathrm{M} 2,45-50 \mathrm{~cm}, \mathrm{n}=1$ M3, $50-55 \mathrm{~cm}, \mathrm{n}=9$ M4, 63-68 cm, $\mathrm{n}=1$ M4, $68-73 \mathrm{~cm}, \mathrm{n}=3$ $\mathrm{M} 4,73-75 \mathrm{~cm}, \mathrm{n}=6$ $\mathrm{M} 5,75-80 \mathrm{~cm}, \mathrm{n}=7$ M5, 80-85 cm, $\mathrm{n}=4$ M7, $110-115 \mathrm{~cm}, \mathrm{n}=4$ M7, $120-125 \mathrm{~cm}, \mathrm{n}=11$ M7, 125-128 cm, $\mathrm{n}=18$ 2Bw, 128-133 cm, $\mathrm{n}=24$ 2Bw, 138-143 cm, $\mathrm{n}=9$ 2Bw, 143-145 cm, $\mathrm{n}=4$ 2CBw, 155-170 cm, n=1 $2 \mathrm{CBw}, 170-180 \mathrm{~cm}, \mathrm{n}=2$ 2CBw, $230-235 \mathrm{~cm}, \mathrm{n}=1$

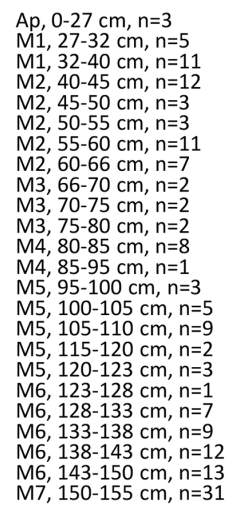

(a) ABR W2

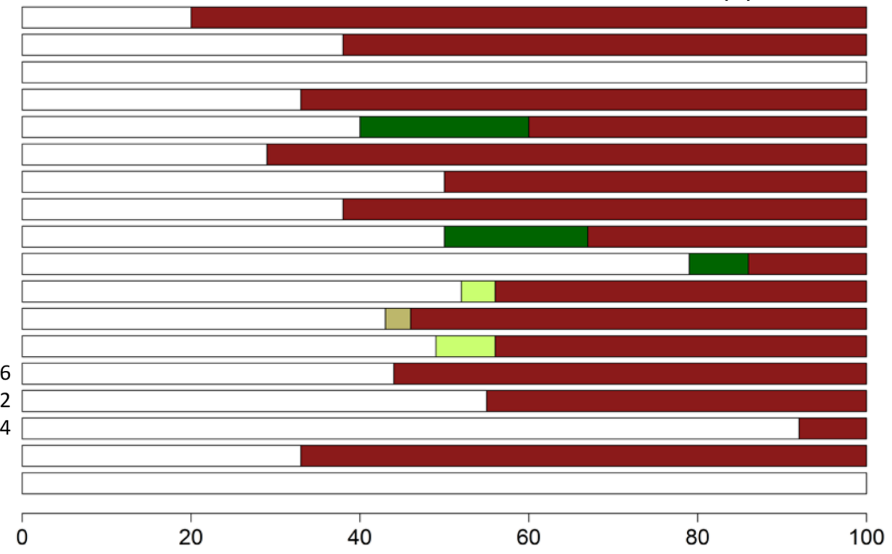

(b) ABR SA1

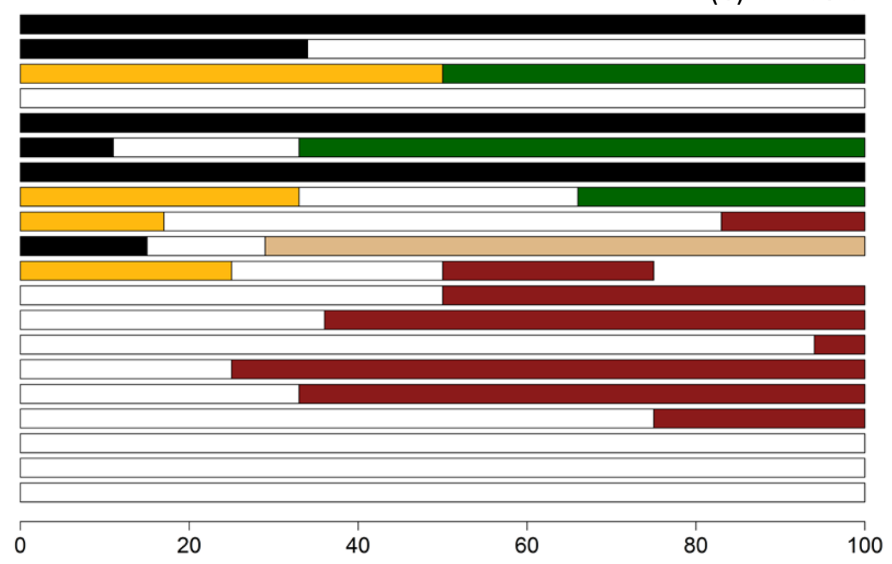

(c) ABR SA2

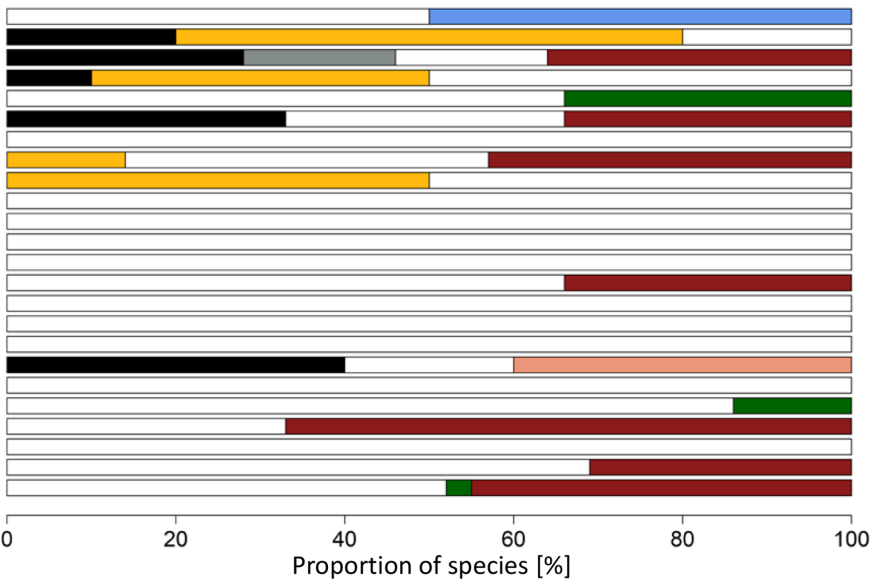

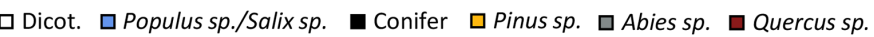

Figure 6. Percentage distribution of charcoal taxa for different sampling depths at the profiles ABR W1 (a), ABR SA1 (b) and ABR SA2 (c) ( $n$ is the number of identified charcoal fragments). Particle size ranges: $1-2,>2 \mathrm{~mm}$. 


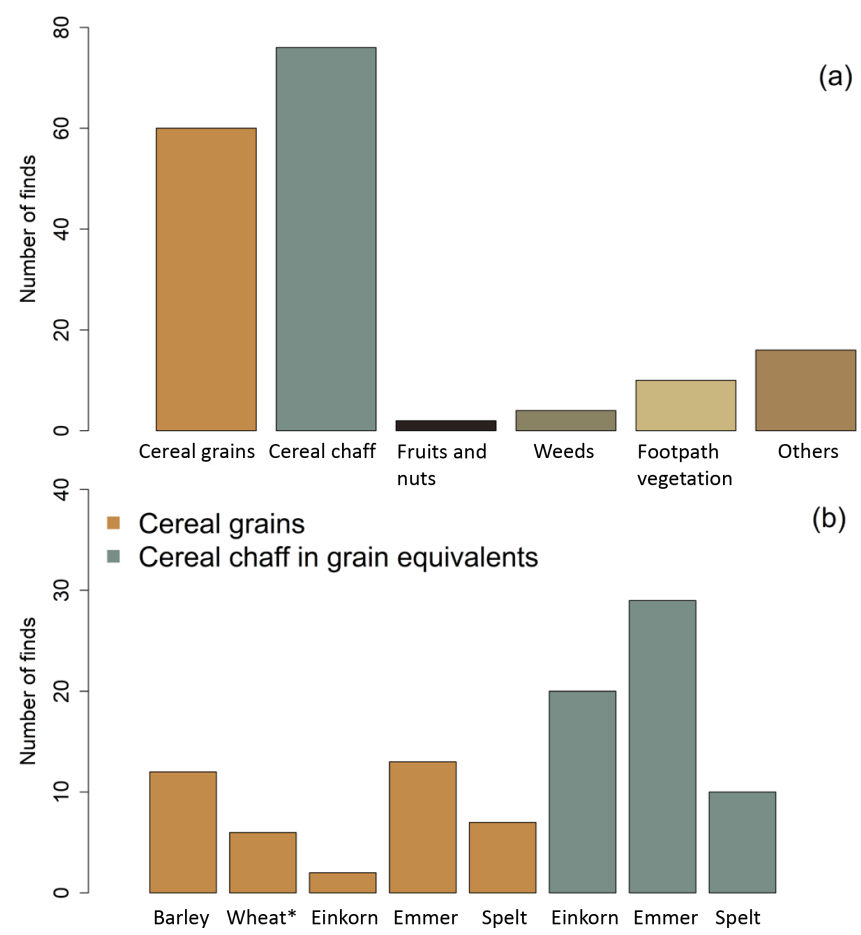

Figure 7. Charred plant macro remains identified in the archaeological features of Anselfingen. Amount of plant macrofossils from the main economic and ecological groups (a) and amount of the main archaeological finds of cereal crops (b). Wheat*: fresh threshing wheat.

originates exclusively from hulled wheats, namely einkorn, emmer and spelt. Figure $7 \mathrm{~b}$ shows the grain equivalents for the chaff, i.e., how many grains were developed in the glumes and spikelets of the respective species. A fragment of hazelnut (Corylus avellana) shell and a nutlet that probably derived from a raspberry, blackberry or dewberry (see Rubus) indicate the use of nuts and fruits from the surrounding vegetation. The number of wild plant finds was also low since only a few seed remains from weeds and footpath vegetation occur in the studied material (Fig. 7a).

\subsection{Micromorphology}

Two thin sections from the 2Apb horizon at the ABR SA2 profile were analyzed to further support MBA plowing activity. The thin section from the upper part of the $2 \mathrm{Apb}$ horizon (ABR SA2, 183-193 cm) had a channel to a weakly developed angular blocky microstructure with few partially accommodating planes. A dark brown limpidity, with an undifferentiated $b$-fabric, was pronounced for most parts of the micromass, with the exception of rounded peds within the groundmass, which showed a light brown limpidity and stipple-speckled to mosaic-speckled $b$-fabric. Despite the non-calcareous micromass, fragments of limestone and oval pellets of micritic calcium carbonate occurred. Through- out the thin section there were small fragments of charcoal and fragments of basaltic, metamorphic and magmatic rocks (Fig. 8a). Partially laminated, very dusty, thick (up to $1600 \mu \mathrm{m})$ dark brown clay coatings with embedded coarse material (quartz and feldspars) with a size of up to $700 \mu \mathrm{m}$ were particularly common in the macrochannels (Fig. 8b).

The thin section from the lower part of the $2 \mathrm{Apb}$ horizon (ABR SA2, 190-200 cm) had a well-developed subangular to angular blocky microstructure with well to partially accommodating planes (Fig. 8c). A dark brown limpidity of the micromass with a predominantly undifferentiated $b$-fabric, was pronounced for about two thirds of the thin section, with the exception of rounded and angular peds within the groundmass, which showed a light brown limpidity and stipplespeckled to mosaic-speckled $b$-fabric. The last third is covered by an almost rectangular area with sharp boundaries and a light brown limpidity of the micromass (Fig. 8d), which had a stipple-speckled, mosaic-speckled and striated $b$-fabric. In many parts, granostriated $b$-fabric was present. Within this area, bands, inclined at about $45^{\circ}$, alternate with coarse material "floating" in fine material with bands consisting mainly of clay and silt - micromass with mosaic to striated $b$-fabric (Fig. 8e). Additionally, large (up to $2000 \mu \mathrm{m}$ ) rounded to subrounded peds frequently occurred (Fig. 8f). The coarse material consisted mainly of basaltic fragments and weathered volcanic shards, limestone fragments, micritic pellets and, to a lesser extent, magmatic and metamorphic fragments and fragments of charcoal.

Many small coprolites $(50-100 \mu \mathrm{m})$ could be detected under fluorescent light. Some of the micritic carbonate pellets showed green autofluorescence at $470 \mathrm{~nm}$. Similar to the upper thin section, very dusty, thick (however only up to $800 \mu \mathrm{m}$ ) dark brown clay coatings, together with coarse material (metamorphic and magmatic rock fragments) with a size of up to $2000 \mu \mathrm{m}$, were particularly common in the macrochannels.

\subsection{Biogeochemical proxies}

Relative changes in polycyclic aromatic hydrocarbon (PAH) input were indicated by PAH to SOC normalization. The suite of individual PAHs was dominated by phenanthrene, fluoranthene and pyrene for all horizons of the analyzed profiles ABR M, ABR W1 and ABR SA2 (Fig. 9ac). The amounts of anthracene, methylated phenanthrenes, benz[a]anthracene and chrysene were low for all samples. The suite of PAHs was most complete in ABR M, as well as in the upper horizons of ABR W1 and ABR SA2. The maximum concentration of phenanthrene was observed in the buried topsoil and subsoil horizons of ABR M (2Bwg, $110-115 ; 2 \mathrm{CBg}, 160-165 \mathrm{~cm})$. In the M5 horizon of ABR $\mathrm{SA} 2$, no PAHs were detected. The sum of three-ring PAHs (phenanthrene, anthracene, methylated phenanthrenes) dominated the lower horizons, while four-ring PAHs (fluoranthene, pyrene, chrysene, benz[a]anthracene) revealed consid- 
Table 2. Phytolith concentrations, relative abundances of phytoliths (monocotyledonous, dicotyledonous) and anatomical origin of phytoliths (grasses, dicotyledonous) of selected profiles. Percentages are calculated over the total number of morphotypes identified in each soil sample; at least 200 morphotypes were identified in each sample (n.i.: not identified).

\begin{tabular}{|c|c|c|c|c|c|c|c|c|c|c|c|}
\hline \multirow[t]{3}{*}{ Profile } & \multirow[t]{3}{*}{ Horizon } & \multirow{2}{*}{$\begin{array}{r}\text { Sampling } \\
\text { depth }\end{array}$} & \multirow{2}{*}{$\begin{array}{r}\text { Phytolith } \\
\text { conc. }\end{array}$} & \multicolumn{3}{|c|}{ Rel. abundances } & \multicolumn{3}{|c|}{ Monocot. grasses } & \multicolumn{2}{|c|}{ Dicot. } \\
\hline & & & & Monocot. & Dicot. & Weathered & $\begin{array}{r}\text { Leaves } \\
\text { and } \\
\text { stems }\end{array}$ & Inflorescences & $\begin{array}{l}\text { Short } \\
\text { cells }\end{array}$ & $\begin{array}{r}\text { Leaves } \\
\text { and } \\
\text { stems }\end{array}$ & $\begin{array}{r}\text { Wood } \\
\text { and } \\
\text { bark }\end{array}$ \\
\hline & & {$[\mathrm{cm}]$} & $\begin{array}{r}\text { [number } \\
\text { per gram } \\
\text { sediment] }\end{array}$ & \multicolumn{8}{|c|}{$[\%]$} \\
\hline ABR W1 & Ap & $0-10$ & 3428 & 43 & 21 & 36 & 40 & 10 & 50 & 2 & 19 \\
\hline ABR W1 & M5 & $180-185$ & 5174 & 59 & 16 & 25 & 52 & 8 & 40 & 4 & 12 \\
\hline ABR W1 & M5 & $190-195$ & 15948 & 60 & 20 & 20 & 43 & 26 & 31 & 3 & 17 \\
\hline ABR W1 & M5 & 200-206 & 17111 & 52 & 18 & 30 & 56 & 15 & 29 & 5 & 13 \\
\hline ABR W1 & M6 & 206-211 & 26501 & 62 & 15 & 23 & 52 & 15 & 33 & 4 & 11 \\
\hline ABR W1 & M6 & $211-216$ & 10459 & 57 & 19 & 24 & 51 & 8 & 41 & 3 & 16 \\
\hline ABR W1 & IIP-fAh & $216-221$ & 36401 & 60 & 19 & 21 & 55 & 16 & 29 & 4 & 14 \\
\hline ABR W1 & IIP-fAh & $226-231$ & 42185 & 61 & 17 & 22 & 56 & 7 & 37 & 4 & 13 \\
\hline ABR W1 & IISdw-P & $240-282$ & 7041 & 51 & 9 & 40 & 55 & 10 & 35 & 2 & 6 \\
\hline ABR W2 & M6 & 190-195 & 735215 & 81 & 8 & 11 & 77 & 0 & 23 & 100 & 0 \\
\hline ABR W2 & M6 & $195-200$ & 523841 & 79 & 11 & 10 & 82 & 0 & 18 & 100 & 0 \\
\hline ABR W2 & M6 & 200-205 & 908928 & 85 & 8 & 7 & 88 & 3 & 9 & 100 & 0 \\
\hline ABR W2 & M6 & $205-210$ & 753596 & 93 & 5 & 2 & 76 & 0 & 24 & 100 & 0 \\
\hline ABR W2 & M6 & $210-215$ & 670884 & 87 & 10 & 3 & 78 & 3 & 19 & 100 & 0 \\
\hline ABR W2 & IIP-fAh & $215-220$ & 1481459 & n.i. & n.i. & n.i. & n.i. & n.i. & n.i. & n.i. & n.i. \\
\hline ABR W2 & IIP-fAh & $220-225$ & 1366765 & 78 & 12 & 10 & 71 & 2 & 27 & 95 & 5 \\
\hline ABR W2 & IIP-fAh & $225-230$ & 590335 & 73 & 20 & 7 & 58 & 3 & 39 & 67 & 33 \\
\hline ABR W2 & IISdw-P & $230-235$ & 318593 & 75 & 14 & 11 & 77 & 4 & 19 & 100 & 0 \\
\hline ABR SA2 & Ap & $0-27$ & 356075 & 43 & 57 & 0 & 67 & 0 & 33 & 100 & 0 \\
\hline ABR SA2 & M7 & $170-172$ & 1246262 & 75 & 12 & 13 & 56 & 5 & 39 & 100 & 0 \\
\hline ABR SA2 & IIfAp & $172-177$ & 2646775 & 66 & 20 & 14 & 65 & 4 & 31 & 85 & 15 \\
\hline ABR SA2 & IIfAp & $177-182$ & 3242155 & 83 & 14 & 3 & 68 & 1 & 31 & 97 & 3 \\
\hline ABR SA2 & IIfAp & $182-187$ & 2288357 & 72 & 20 & 8 & 59 & 4 & 37 & 98 & 2 \\
\hline ABR SA2 & IIfAp & $187-190$ & 2380259 & 76 & 13 & 11 & 72 & 3 & 25 & 94 & 6 \\
\hline
\end{tabular}

erable amounts in the upper first horizons of $A B R \mathrm{M}(\mathrm{M} 1$, 20-25 cm; M2, 50-55 cm) and ABR SA2 (Ap, 0-27 cm; M1, $27-32 \mathrm{~cm}$ ).

The ratio of fluoranthene to fluoranthene plus pyrene (Flu / Flu + Py) was higher than 0.5 in $77 \%$ of the values. The ratio was lower in ABR W1 (M6, 206-211 cm: 0.41) and in ABR SA2 (Ap, 0-27 cm: 0.46; M7, 150-155 cm: 0.24). The phenanthrene to phenanthrene plus the sum of methylated phenanthrenes ranged between 0.76 and 1 (Fig. 9d). The pattern for both ratios was similar and with a distribution of the ratios independent of the sum of PAH concentrations.

The urease activity to microbial biomass $\left(\mathrm{C}_{\text {mic }}\right)$ ratio was determined for colluvial profiles ABR W1, ABR W2, ABR WA1, ABR WA2, ABR SA1 and ABR SA2 and varied between 0 and $2.1 \mu \mathrm{gN} \mu \mathrm{gC} \mathrm{mic}{ }^{-1}$ (Fig. 10). All profiles showed a comparable trend with increasing values with greater soil depth. A peak in the urease activity $/ C_{\text {mic }}$ ratio was either reached in the buried topsoil horizon (ABR W1,
2Bwig / Ahb, 216-235 cm; ABR WA1, 2Bwig / Ahb, 220$260 \mathrm{~cm}$; ABR SA1, 2Bw, 128-145 cm) or in the deepest colluvial horizon (ABR W2, M6, 185-215 cm; ABR WA2, M7, $205-225 \mathrm{~cm}$ ) and was in all cases considerably higher than the ratios of the modern topsoil horizon. Only for ABR SA2 did the peak in urease activity $/ \mathrm{C}_{\mathrm{mic}}$ ratio occur in the upper part of the profile (M6, 123-150 cm). Besides the maximum ratios, smaller peaks were also observed in several profiles. The peak value at ABR SA1 was remarkable in that it far exceeded other values from the same profile. A positive correlation of urease $\left[\mu \mathrm{gN} \mathrm{gTS}{ }^{-1} \times 2 \mathrm{~h}\right]$ and SOC was observed within 0 and $130 \pm 20 \mathrm{~cm}$ for most of the analyzed profiles $\left(R^{2}: 0.82\right)$. Below this depth, the correlation of urease and SOC was weaker $\left(R^{2}: 0.44\right)$. Clay and urease activity was not (ABR W1, ABR W2) or only weakly positively correlated $\left(R^{2}: 0.37\right.$, ABR SA2) (Table S3).

Steroid compositions were analyzed for selected horizons of profiles ABR W1 and ABR SA1 (Fig. 11a-b). In total, 11 

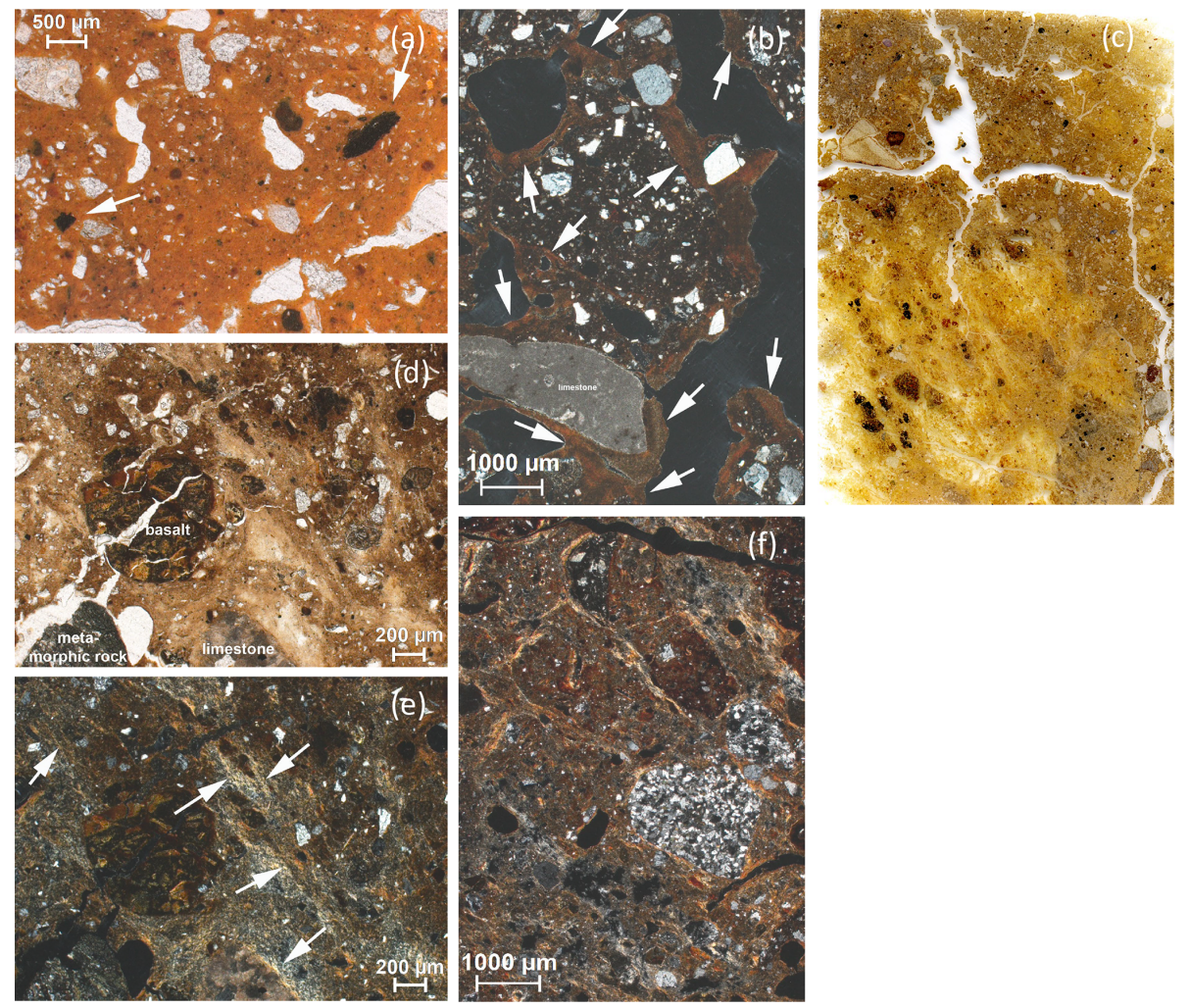

Figure 8. Micromorphological analysis of the buried plow horizon (2Apb). (a) White arrows point at fragments of charcoals $(<500 \mu \mathrm{m})-$ ABR SA2 183-193 cm: OIL, ppl; (b) very dusty clay coating (white arrows) with incorporated coarse material - ABR SA2 183-193 cm: $\mathrm{xpl}$; (c) scan of the thin section $6 \times 9 \mathrm{~cm}-$ ABR SA2 180-190 cm; (d) compacted (low porosity) rounded to subrounded peds and rock fragments; some channels and one partially accommodating plane are present. Some peds are surrounded by a granostriated $b$-fabric - ABR SA2 180-190 cm; xpl; (e, f) about $45^{\circ}$ inclined bands with alternating coarse and fine material; mosaic to striated $b$-fabric (white arrows) ABR SA2 180-190 cm; (e) ppl; (f) xpl.

different compounds were identified comprising the molecular groups of stanols (coprostanol, epicoprostanol, $5 \beta$ stigmastanol, epi-5 $\beta$-stigmastanol), stanones (cholestanone, coprostanone, cholestenone) and $\Delta^{5}$-sterols (cholesterol, $\beta$ sitosterol, ergosterol, $\beta$-stigmasterol). At ABR W1, coprostanol, epicoprostanol, cholestanone and cholesterol were dominating the molecular assemblages, whereas the relative amount of coprostanol and epicoprostanol was decreasing from horizon M6 (206-211 cm) to 2Bwig (235-240 cm), and an opposite trend was observed for cholestanone and cholesterol. At ABR SA1, cholestanone also increased with depth, while the relative proportions of coprostanol and epicoprostanol were less distinct compared to ABR W1. Further, at ABR SA1, considerable proportions of $\beta$-sitosterol and $5 \beta$ stigmastanol and epi-5 $\beta$-stigmastanol were observed.

At ABR W1, the ratio of coprostanol / (coprostanol+epi$5 \beta$-stigmastanol) $\times 100$ was mainly greater than $73 \%$ for the colluvial horizon M6 $(206-211 \mathrm{~cm})$ and the buried topsoil 2Bwig / Ahb (216-221, 226-231 cm). In the buried subsoil horizon 2Bwig (235-240 cm), a single value below $38 \%$ was calculated. The profile ABR SA1 showed ratios below $38 \%$ which mainly occurred in the buried subsoil horizon $2 \mathrm{Bw}$
$(133-138,138-145 \mathrm{~cm})$ and above $73 \%$ in the colluvial horizon M7 (110-115 cm) and buried subsoil horizon 2Bw (133$138 \mathrm{~cm}$ ) (Fig. 11c).

The heavy metal contents showed two main patterns (Fig. 12). First, the $\mathrm{Pb}, \mathrm{Cu}$ and As contents were significantly lower than the $\mathrm{Zn}, \mathrm{Ni}$ and $\mathrm{Cr}$ contents for all colluvial profiles. Secondly, different values were observed for the different soil substrates, with the highest heavy metal contents in the (b) basaltic sediments of the Hohenhewen volcano and the lowest in the (a) sediments of the Younger Juranagelfluh. In most cases, the 25th and 75th quartile \pm 1.5 interquartile range mimicked the natural variation of the heavy metal contents, depending on the substrate, according to the data of the geological state office of BadenWürttemberg (LGRB, 2020). Positive outliers, which indicate human influence, were detected at the colluvial profiles ABR S30 $(\mathrm{Cu}, \mathrm{M} 4$ horizon, $110-115 \mathrm{~cm}$, sediments of the Younger Juranagelfluh), ABR WA2 (As, M7, 220-225 cm; $\mathrm{Pb}, \mathrm{Ap}, 0-20 \mathrm{~cm}$, sediments of the Hohenhewen volcano) and ABR SA1 (Zn, M6-M7, 100-128 cm, sediments of the Hohenhewen volcano). Heavy metals analyzed from sediment samples from the Younger Juranagelfluh and the glacial and 


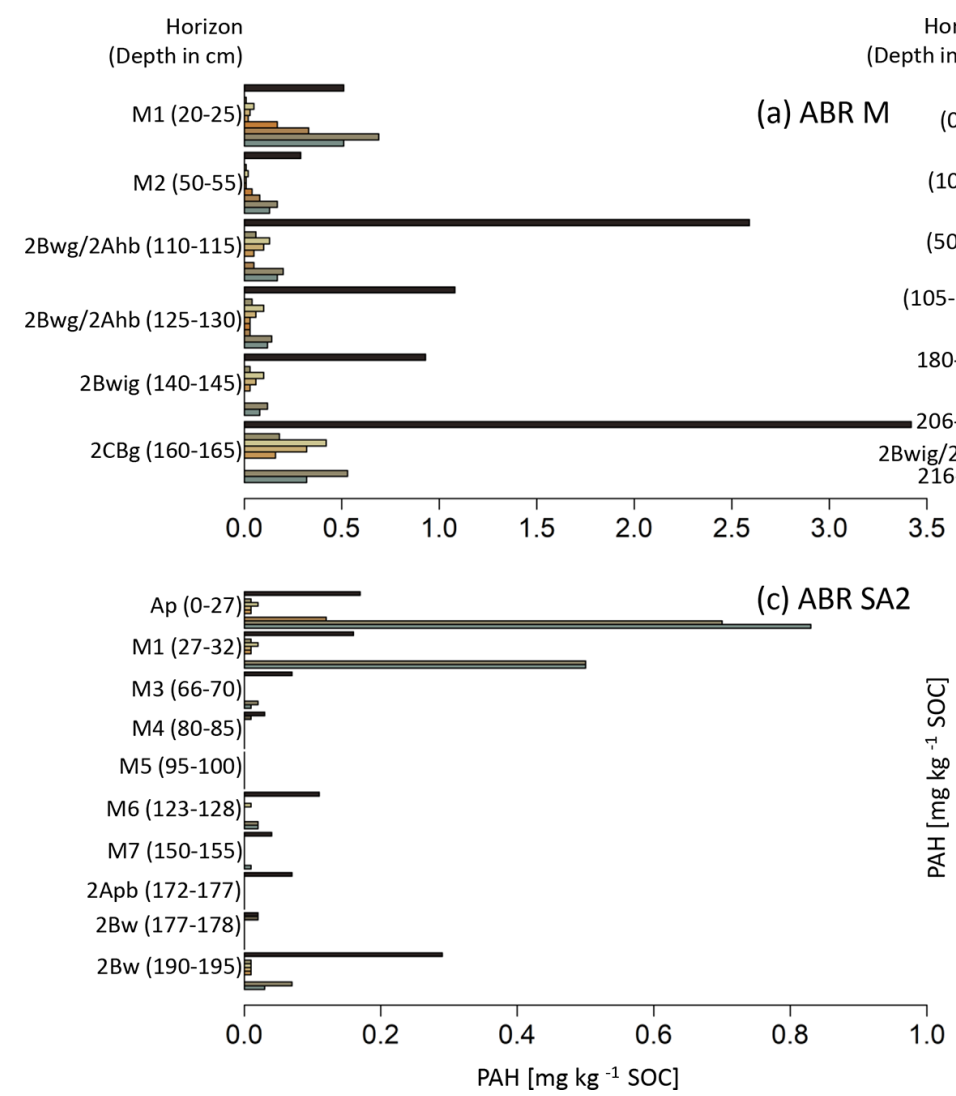

Horizon
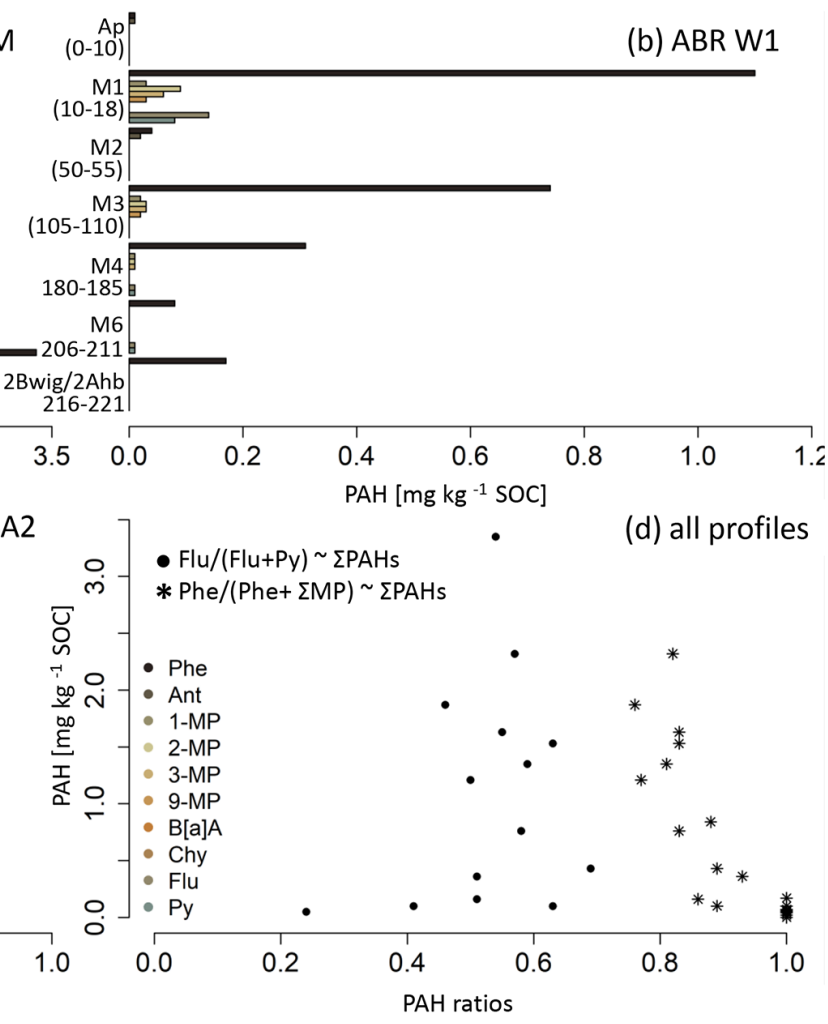

Figure 9. Polycyclic aromatic hydrocarbons (PAHs) with SOC normalization (a-c) of selected colluvial profiles and sampling depths (cm); PAH ratios vs. sum of PAHs (d). Phe: phenanthrene, Ant: anthracene, 1-MP: 1-methyl-phenanthrene, 2-MP: 2-methyl-phenanthrene, 3-MP: 3-methyl-phenanthrene, 9-MP: 9-methyl-phenanthrene, B[a]A: benz [a]anthracene, Chy: chrysene, Fl: fluoranthene, Py: pyrene.

fluvioglacial sediments of the Würm glaciation correlated mostly with $\mathrm{CaCO}_{3}$. No correlation was observed between heavy metals and SOC and heavy metals and $\mathrm{pH}$ value. In addition, the heavy metal contents from samples of the sediments of the Hohenhewen volcano were not correlated with $\mathrm{CaCO}_{3}$, SOC and $\mathrm{pH}$ value (Table S4).

\subsection{Animal bones}

In total, 415 animal bones from different MBA features (onsite) with a total weight of $1076 \mathrm{~g}$ were investigated at the ABR site (Table 3). In total, $21 \%$ of the animal bones could be assigned to their species while $79 \%$ had to stay unidentified due to their high level of fragmentation. Considering only those bones that were assigned to species, most of them belonged to sheep/goat $(30 \% ; 95 \mathrm{~g})$, cattle $(30 \% ; 290 \mathrm{~g})$ and pig $(14 \% ; 47 \mathrm{~g})$. Wild animal species (e.g., roe deer, deer, boar, wolf, wild cattle) made up $17 \%$ (187 g) of the elements identified to species.

The taphonomic analysis revealed natural and human modifications of animal bones. Most of the assemblages were affected by insect damage or by root damage in different stages. The burning of bones could be identified with a low rate of $0.7 \%$ and occurred mainly in the fillings of pits and deposited vessels. Anthropogenic traces such as cutmarks were documented on only $0.3 \%$ of the animal bones. Another human modification was observed in a piece of antler (most likely red deer) from an MBA house, which had been worked into a point (tool or hunting object). Another specimen from an MBA fire pit showed slight polishing of one of the edges. Carnivore marks could only be identified on one specimen from the MBA sample.

\subsection{Off-site pollen profiles}

For the Grassee profile (Fig. 13), which consisted mainly of fen peat, six local pollen assemblage zones (LPAZs) could be distinguished (according to Bastin, 1979):

1. (2600-2500 BCE): NAP (non-arboreal pollen) low; $F a$ gus and Corylus codominant, Betula subdominant; Corylus increasing, Fagus decreasing;

2. (2500-2200 BCE): NAP increasing to $>5 \%$; Corylus predominant, slowly decreasing; Fagus subdominant, later codominant, increasing, micro-charcoal peak in the beginning of the zone; 


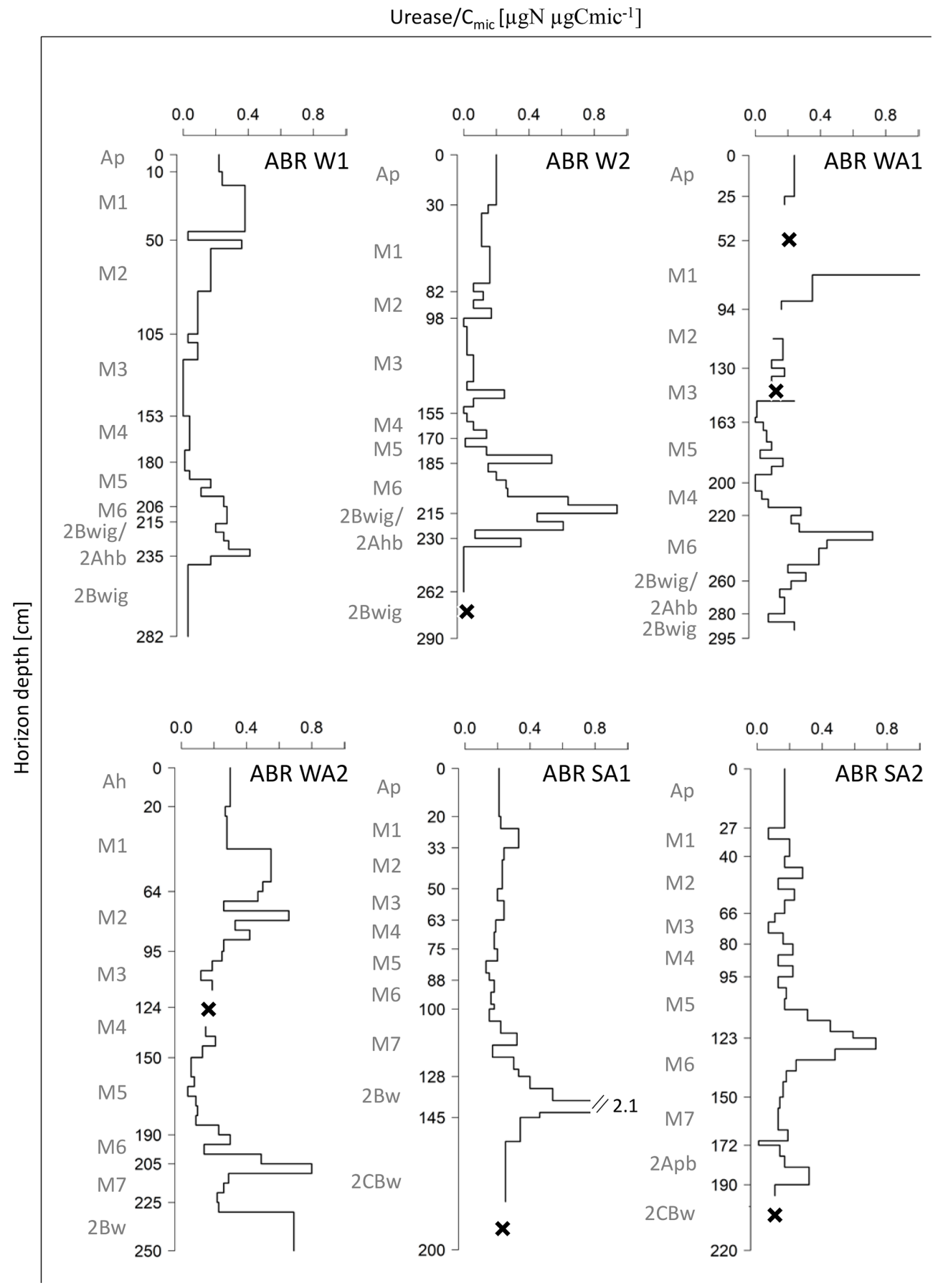

Figure 10. Depth profiles of Urease / $C_{\text {mic }}$ ratio of selected colluvial profiles. "x": not analyzed.

3. (2200-2000 BCE): NAP low; a sequence of Fagus, Betula and finally Corylus peak;

4. (2000-1600 BCE): NAP peak, Fagus predominant, Corylus and Quercus subdominant;

5. (1600-850 BCE): NAP initially reduced then with a maximum; Fagus predominant, Corylus and Quer- cus subdominant; Quercus decreases slightly from 1100 BCE onwards, a weak micro-charcoal peak;

6. (850-700 BCE): NAP decreasing, Fagus increasing;

Between 2000 and $800 \mathrm{BCE}$, the pollen curves of major anthropogenic indicators like Artemisia and Plantago lanceolata were continuous, with the highest values in zone 5 (1600-850 BCE) exactly like the non-arboreal-pollen (NAP) 
(a) (ABR W1)

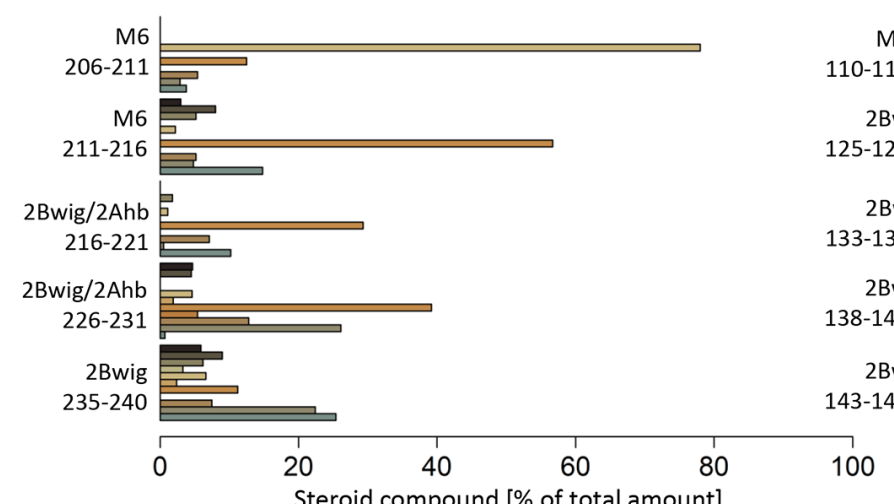

(b) (ABR SA1)

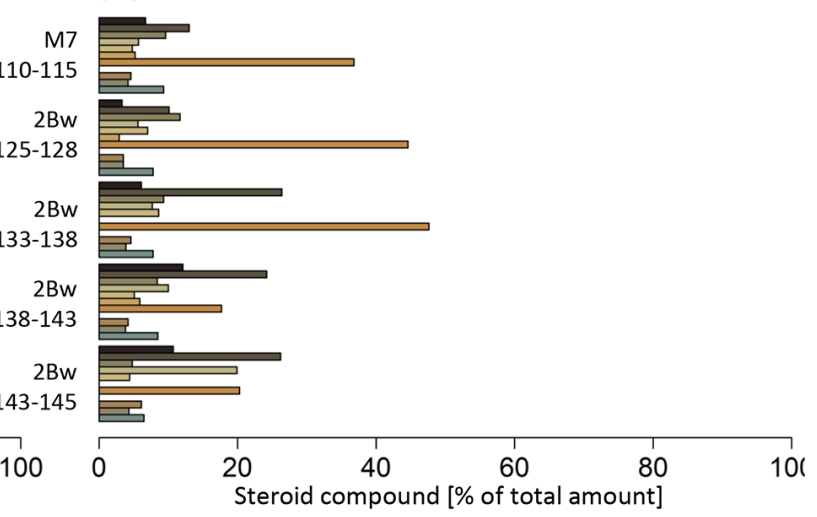

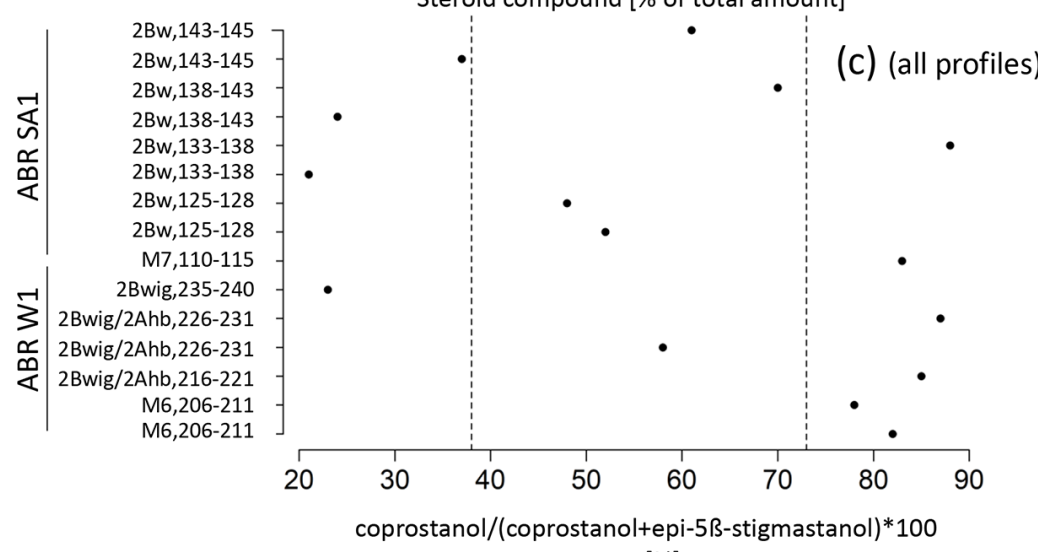

[\%]

Figure 11. Steroid compounds as percent of total amount (a-b) of selected colluvial profiles and sampling depths (cm). Steroid ratio according to Leeming et al. (1997) (c). Values < $38 \%$ indicate herbivorous faeces; values $>73 \%$ indicate omnivorous faeces.

Table 3. Absolute $(n)$ and relative number $(n$ in $\%$ ) of animal bones and absolute ( $\mathrm{g}$ ) and relative weight (mass in \%) of species-specific animal bones which were assigned to their species.

\begin{tabular}{lrrrr}
\hline Species & $n$ & $n(\%)$ & Weight $(\mathrm{g})$ & Weight $(\%)$ \\
\hline Cattle (Bos primigenius) & 30 & 34 & 290 & 27 \\
Horse (Equus caballus) & 1 & 1 & 33 & 3 \\
Pig (Sus scrofa domesticus) & 14 & 16 & 47 & 4 \\
Goat/sheep (Capra/Ovis) & 27 & 30 & 95 & 9 \\
Boar (Sus scrofa) & 5 & 6 & 50 & 5 \\
Wolf (Canis lupus) & 3 & 3 & 4 & 0 \\
Deer (Capreolus capreolus) & 1 & 1 & 0.8 & 0 \\
Roe deer (Cervus elaphus) & 5 & 6 & 12 & 1 \\
Wild cattle (Bison bison) & 3 & 3 & 120 & 11 \\
\hline Total & 89 & 100 & 1076 & 100 \\
\hline
\end{tabular}

sum. The curves of cereals (Cerealia-type, Triticum-type and Hordeum-type) were however discontinuous. Changes in the arboreal pollen (AP) composition are moderate. After 2000 BCE, Betula decreased slightly. Quercus reached its highest values in LPAZ 4 and 5. The dominating tree during the whole period was Fagus, while coniferous trees like
Abies and Picea, both minor components, increased in the 10th century BCE.

For the Hartsee mire (Fig. 14), where peat and lake sediments alternate, seven LPAZs could be distinguished during the Bronze Age:

1. (2700-2600 BCE): NAP low; predominance of Fagus

2. (2600-2500 BCE): NAP still low; Corylus predominant, Fagus and Quercus subdominant; Betula has a weak maximum;

3. (2500-1900 BCE): Slight increase of the NAP sum; predominance of Fagus; subdominance of Corylus (decreasing) and Quercus, a pronounced micro-charcoal peak;

4. (1900-1750 BCE): NAP decrease, towards the upper limit increase; predominance of Fagus, subdominance of Corylus (prevailing) and Quercus; Corylus increasing, Betula decreasing;

5. (1750-1550 BCE): NAP increase to $10 \%$, parallel to a micro-charcoal peak; Fagus dominates but decreases; towards the upper limit codominance of Quercus and Fagus; 

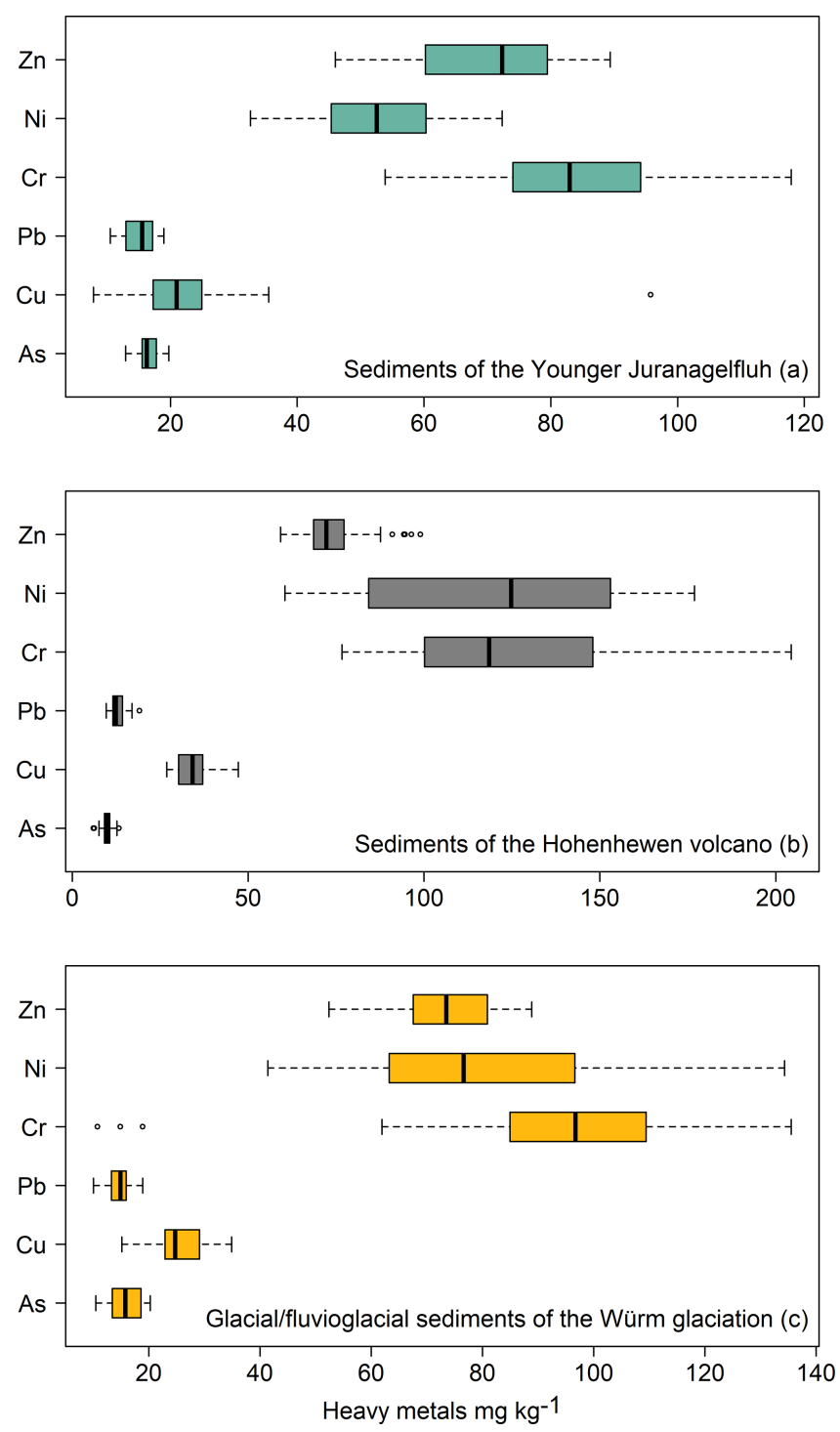

Figure 12. Heavy metal contents of the soil profiles ABR W1, ABR W2, ABR M, ABR S30, ABR SA1 and ABR SA2 according to their soil substrates: (a) sediments of the Younger Juranagelfluh ( $n$ : 113); (b) sediments of the Hohenhewen volcano $(n$ : 93); (c) glacial/fluvioglacial sediments of the Würm glaciation $(n$ : 38). The box plots show median, 25th $\left(Q_{1}\right)$ to 75 th $\left(Q_{3}\right)$ percentile (i.e., interquartile range, IQR), data minimum $\left(Q_{1}-1.5 \times \mathrm{IQR}\right)$, data maximum $\left(Q_{3}+1.5 \mathrm{IQR}\right)$ and outliers.

6. (1550-1050 BCE): NAP increasing to $15 \%-20 \%$ in line with high micro-charcoal increase and peak, codominance of Fagus, Quercus and Corylus; Carpinus curve \pm continuous;

7. (1050-700 BCE): NAP slightly decreasing; Quercus slightly predominant, Fagus, Corylus and Betula subdominant.

During the Bronze Age, the anthropogenic indicators Plantago lanceolata and Artemisia were continuously present. The cereal pollen (especially Triticum-type and Hordeum-type) showed almost continuous occurrence, with their curves following the same trend as the curve of the NAP sum. After a minimum during the 18 th/17th century BCE, Betula was increasing, with some fluctuations, and gained a maximum of $15.5 \%$ in the 12th century BCE. Another peak $(20.4 \%)$ occurred in the late 11 th century BCE. From 930 BCE onwards, the overall occurrence of Betula was continuous $(11 \%-15 \%)$. After a maximum in the 18th century BCE, Corylus decreased continuously, apart from minor peaks. Quercus showed a peak in the 17th/16th century BCE and retained a strong significance afterwards. A more distinct increase was not observed as earlier as the pre-Roman Iron Age. Fagus, the dominating tree at the beginning of the Bronze Age, decreased from the 17th century BCE onwards. After a recovery phase in the 13th/11th century BCE, it decreased again. The micro-charcoal record shows a first peak at ca. 2250 BCE and two more pronounced peaks at ca. $1650-1600$ and $1150-1100$ BCE.

\section{Discussion}

\subsection{Phases of colluvial deposition and land use}

The stratigraphic and chronostratigraphic deciphering of colluvial deposits and buried topsoils based on ${ }^{14} \mathrm{C}$ and OSL dating is fundamental for the reconstruction of land use phases of nearby settlements (Kittel, 2015; Scherer et al., 2021). In the northwestern Alpine foreland, phases of colluvial deposition during the MBA have been reported much less frequently (Schulte and Stumböck, 2000; Vogt, 2014), while related archaeological remains provide evidence of simultaneous human occupation (Dieckmann, 1998; Ehrle et al., 2018; Wissert, 1985).

The summed probability density (SPD) of OSL ages (Fig. 15a) indicates main phases of colluvial deposition during the Middle Bronze Age (MBA), the Iron Age, the Medieval period and modern times. During the Late Neolithic, weak colluviation is observed (M6 in ABR W2, $2700 \pm 400$ BCE; see Table S1), while soil tillage (e.g., hoefarming) of the paleo-surface may have also been responsible for Younger Neolithic OSL signals (2Bwig / Ahb in ABR $\mathrm{W} 1,3300 \pm 400 \mathrm{BCE} ; 2 \mathrm{Bw}$ in ABR SA2, $4400 \pm 700 \mathrm{BCE}$; 2Bwg / Ahb in ABR M, $2500 \pm 300$ BCE). Neolithic soil deposition was also reported by Poręba et al. (2019) and Zádorová et al. (2013) in loess-covered upland sites in Poland and the Czech Republic, where the sedimentation rates were higher, which could be the result of a high erodibility of loess. At the ABR site, the main colluvial deposition began during the MBA, as indicated by the OSL ages from ABR W1 (M6, $1500 \pm 300 \mathrm{BCE}$; M5, $1200 \pm 200 \mathrm{BCE})$ and ABR W2 (GI529, M6, $1300 \pm 300 \mathrm{BCE}$ ) and the formation of about $30 \mathrm{~cm}$ of colluvial deposit. These phases of colluvial deposition are in line with MBA settlement remains but are restricted to the northern surrounding areas of the ABR site 
Grassee, Hegau Region, Southwest Germany

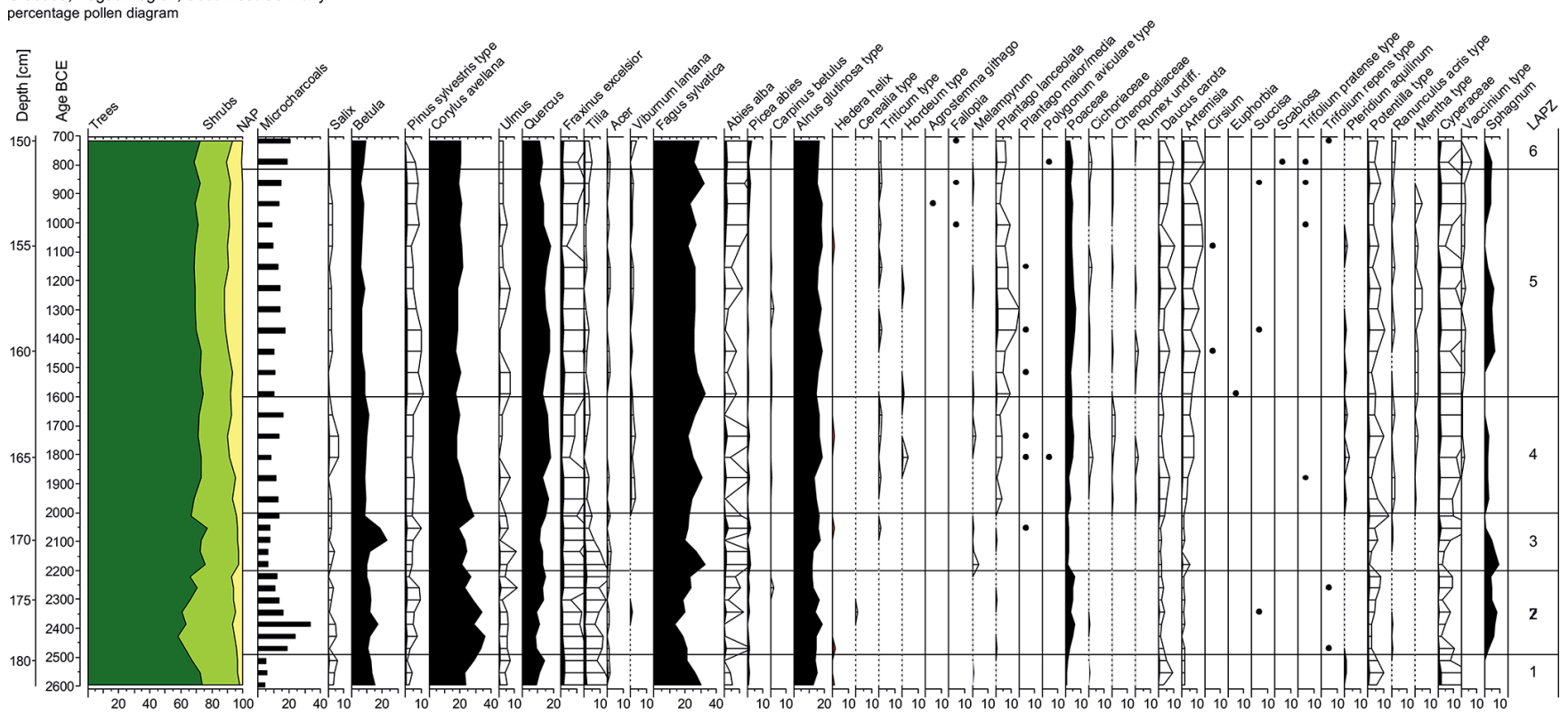

Figure 13. Pollen profile of Grassee mire. NAP: non-airborne pollen. The samples were investigated in increments of $1 \mathrm{~cm}$.

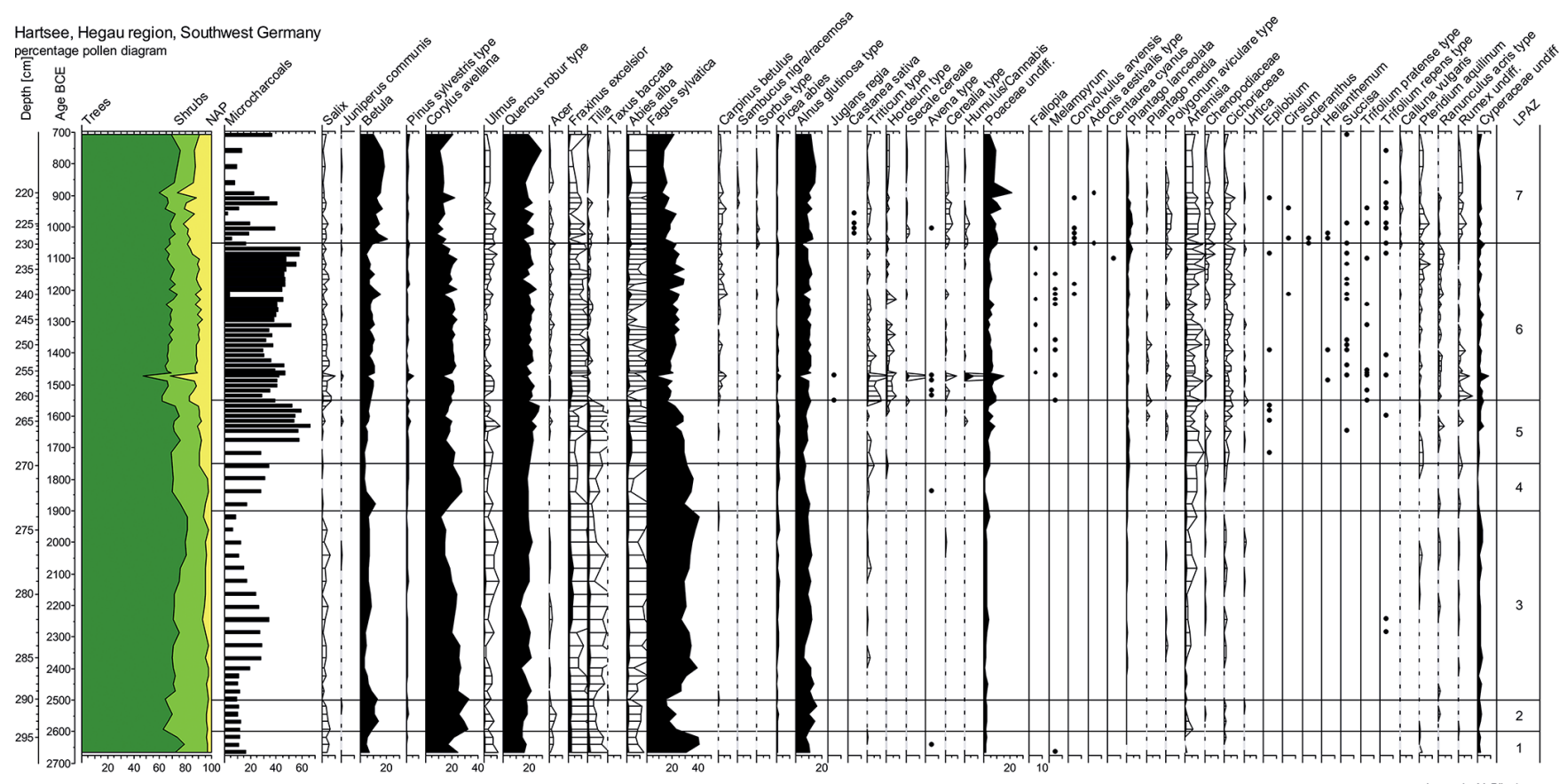

Figure 14. Pollen profile of Hartsee mire. NAP: non-airborne pollen. The samples were investigated in increments of $1 \mathrm{~cm}$.

(ABR W1, ABR W2), while during the MBA no colluvial deposition occurred within the settlement area (ABR M) or south of it (ABR SA1, ABR SA2). However, the OSL signal from the $2 \mathrm{Apb}$ in profile ABR SA2 $(1500 \pm 300 \mathrm{BCE})$ indicates MBA soil tillage of the paleo-surface and the presence of an agricultural field associated with the MBA settle- ment. Pedofeatures indicating prehistoric plowing are scarce (Twardy, 2011), while to the best of our knowledge, an MBA plowing horizon has not yet been documented (see Sect. 4.2.2). Regarding the profile ABR M, colluvial deposition was not expected during the MBA due to its location within the settlement area. Since the Iron Age, colluvial 
deposition occurred across the ABR site as reflected in the higher sedimentation rate compared to the MBA (Fig. 15b). This is in line with the sedimentation history from other study sites and is mostly interpreted as the consequence of increased human impact (e.g., Dotterweich, 2008; Dreibrodt et al., 2010b; Henkner et al., 2017; Lang, 2003). However, the low sedimentation rate during the Roman period is remarkable and contradicts the archaeological finds at the ABR site (Ehrle et al., 2018). Possible explanations are that Roman land use did not contribute to higher soil erosion rates, or Roman land use areas were located elsewhere at the ABR site. It should be noted that the SPDs could also be biased in this respect, as no charcoal was found, and no OSL samples could be taken from the M5 horizon in ABR SA2, which, according to the ages of the over- and underlying horizons M4 and M6, could be dated to the Roman period (Fig. 4).

Higher SPDs of ${ }^{14} \mathrm{C}$ ages often precede phases of colluvial deposition, indicating that landscape opening by local deforestation was responsible for colluvial deposition at the ABR site. During the Neolithic, at least three phases of land use are reflected in the ${ }^{14} \mathrm{C}$ ages (Fig. 15, a). They can be related to the Early (Linear Pottery Culture, 5500-5000 BCE), Younger (Hornstaad Culture, 4100-3800 BCE) and Late Neolithic (Horgen Culture, 3700-2800 BCE), all of which are documented through burials or architectural remains from the ABR site or its close proximity (Ehrle et al., 2018; Hald, 2020, Fig. 14c). During the Bronze Age, the ${ }^{14} \mathrm{C}$ peaks of the SPDs complement the local archaeological record and the MBA depositional phase, indicating human occupation during the Early, Middle and Late Bronze Age (Ehrle et al., 2018; Hald, 2020). The succeeding ${ }^{14} \mathrm{C}$ peaks of the SPD curve correspond to the main phases of colluvial deposition during the Iron Age, Medieval period and modern times.

Based on the phases of colluvial deposition and land use, human occupation during the MBA is reflected in the sedimentary archives at the ABR site. Considering the scarcity of MBA colluvial horizons in the northwestern Alpine foreland, the well-dated colluvial horizons, the buried paleosurfaces and the archaeological features from the MBA provide promising archives for the archaeopedological, archaeobotanical and archaeological reconstruction of on- and near-site land use practices at the ABR site.

\subsection{On-site and near-site Middle Bronze Age land use practices at the Anselfingen site}

\subsubsection{Use of fire, deforestation and forest management}

Prehistoric deforestation and landscape maintenance could have been accompanied by fire practices (Rösch, 2013), which led to the accumulation of charcoal and PAHs in respective colluvial horizons (Tan et al., 2020). The PAH sum of the examined profiles was slightly related to SOC $\left(R^{2}\right.$ : 0.30 ), indicating that soil organic matter (SOM) partially explains the PAH abundances, but other processes might have also contributed to their accumulation (Nam et al., 2018). In the northwestern Alpine foreland, thermophilus deciduous vegetation, comprising the species Quercus, Alnus, Fraxinus, Ulmus and Corylus, was naturally growing before the beginning of anthropogenic disturbances. Since the forests were assumed to be rather dense before human arrival, large-scale deforestation with the help of fire is likely to have occurred afterwards (Lechterbeck, 2001). In the 2Bwg/2Ahb and $2 \mathrm{CBg}$ horizons (ABR M), $\mathrm{PAH}$ distribution points to natural vegetation fires during the Early Holocene, with Pinus, Betula and Poaceae as the natural vegetation and possible fuel source. The higher concentrations of phenanthrene in greater soil depths, compared to all other PAHs, indicate contribution not only of in situ combustion residue inputs, but also of atmospherically transported fire condensates (Lehndorff and Schwark, 2004; Kappenberg et al., 2019). This is also indicated by the phenanthrene to phenanthrene plus the sum of methylated phenanthrenes ratio (Phe / Phe $+\Sigma \mathrm{MP}$ ), which suggests a predominance of complete combustion processes with lower concentrations of methylated phenanthrenes and an excess of fire condensates. In the horizons related to the MBA (2Bwg / Ahb in ABR M; M6 in 2Bwig / Ahb in ABR $\mathrm{W} 1 ; 2 \mathrm{Apb}$ in ABR SA2), we found indications for relatively low combustion temperatures as might have been the case for controlled burning of biomass to maintain land use areas. This is supported by the fluoranthene to fluoranthene plus pyrene ratio $(\mathrm{Fl} / \mathrm{Fl}+\mathrm{Py})$, with values mostly $>0.5$, indicating that the combustion of grass, wood and charcoal (Budzinski et al., 1997; Yunker et al., 2002) was predominant at the ABR site. Moreover, we would expect different combustion processes within the settlement area compared to its surroundings as indicated by several MBA fire places, fire pits and the secondary deposition of heat stones. Indeed, the suites of PAHs were more complete at the ABR M profile (on-site), which is located within the MBA settlement area, compared to the profiles ABR W1 and ABR SA2 (near-site). There, various combustion processes, such as cooking practices, heating of houses and technical application (e.g., metal processing and burning of ceramics), and different fire temperatures may have contributed to the PAH pattern.

In relation to MBA fire use practices, the determination of on-site and near-site charcoal assemblages provides information on natural and human-modified vegetation patterns and, thus, on past land use practices such as deforestation, wood procurement, promotion of individual tree species and forest ecosystems (Jansen and Nelle, 2014; Schroedter et al., 2013). Moreover, different fuel sources can be estimated from the investigation of charcoal assemblages from fireplaces and fire pits (Höpfer et al., 2021). The generally very small size of charcoal fragments in the M horizons may be the consequence of erosional transport, while longer distance aerial transport can be neglected due to fragment sizes $>1 \mathrm{~mm}$ (Whitlock and Larsen, 2002). Hence, an anthracological determination further than dicotyledons was not always achievable. However, the higher abundance of Quercus 


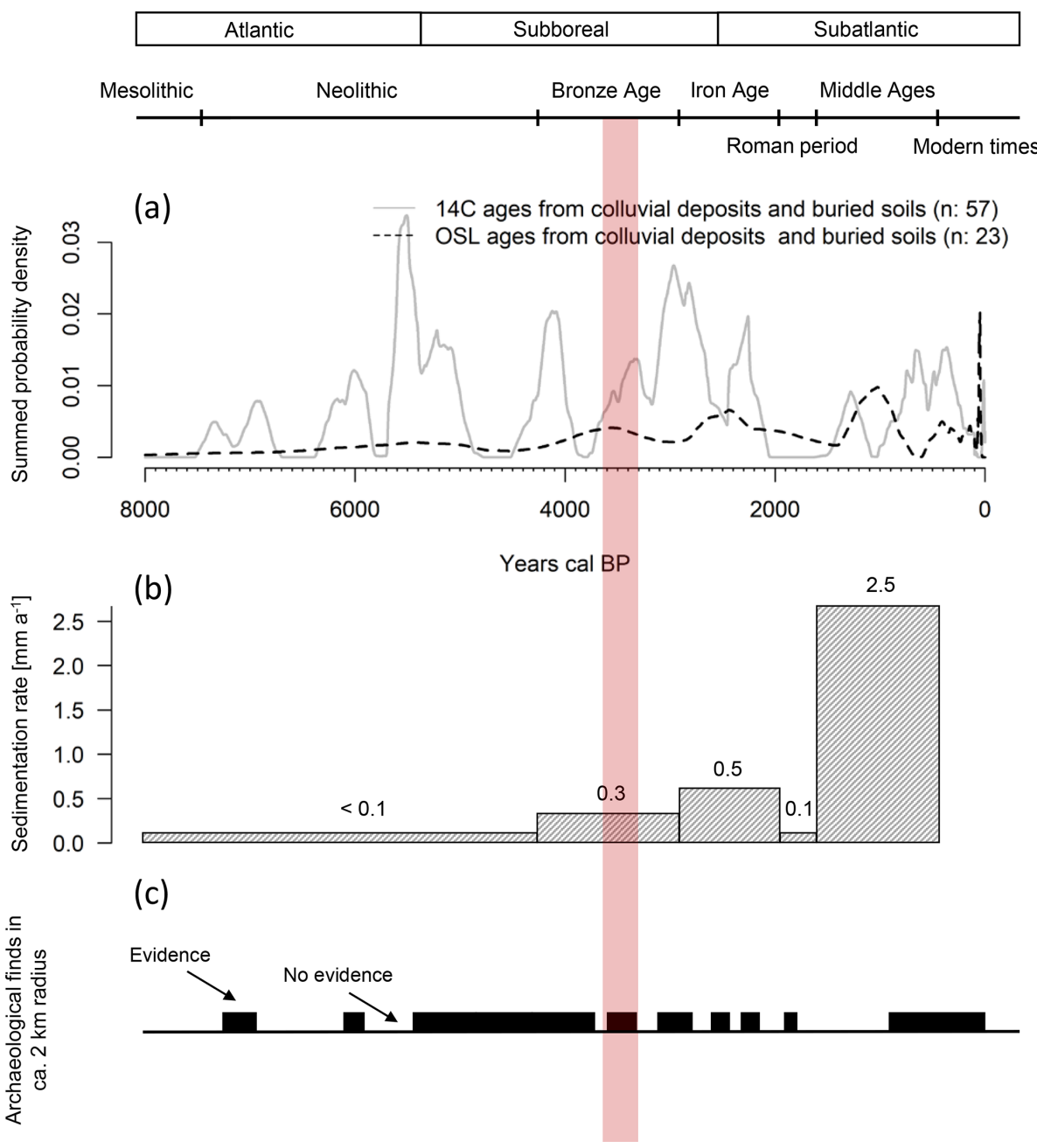

Figure 15. Summed probability density (SPD) curves from AMS ${ }^{14} \mathrm{C}$ and OSL ages (a). Sedimentation rate by depositional ages (OSL) and related to archaeological periods (b). Evidence of archaeological finds within a radius of $2 \mathrm{~km}$ from the Anselfingen settlement site (c). The red bar marks the Middle Bronze Age period.

compared to Fagus in the buried soils and colluvial horizons related to the MBA (2Bwig / Ahb, M6 in ABR W2; 2Bw, M7 in ABR SA1) indicates a shift from thermophilous calciphilous forests consisting of sessile oak and beech to a forest ecosystem dominated by oak. These findings are supported by charcoal assemblages from MBA fire pits at the settlement site of Anselfingen (Höpfer et al., 2021). The MBA fire pits contained about $85 \%$ Quercus charcoal, while $98 \%$ of the total charcoal spectra consisted of Quercus and $\mathrm{Fa}$ gus (Rösch, 1996). Whether Quercus and Fagus were collected intentionally or unintentionally during the MBA cannot be conclusively assessed. However, the very good fuel quality of both taxa, along with the occasionally observed insect holes within the charcoal fragments and the smaller branch diameters, strongly indicates an opportunistic collection of deadwoods following the "principle of least effort" (Höpfer et al., 2021). Naturally, oak mixed forests develop into beech forests, since oak is more light demanding and therefore restricted to drier or alluvial sites, and beeches are faster growing, even in shady areas (Mosandl and Abt, 2016). The potential occurrence of Quercus was probably limited to alluvial areas or drier sites close to the ABR site. Therefore, a human-induced promotion, for different purposes (Bärnthol, 2003), of Quercus appears likely during the MBA, which is also suggested by the off-site palynological record from the pollen archives of Hartsee and Grassee (see Sect. 4.3), where more or less pronounced micro-charcoal peaks occur from ca. 1750-1600 BCE onwards. At Hartsee, the increase of Quercus and decrease of Fagus are accompanied by relative high values of micro-charcoal and several palynological indicators for human impact on the vegetation in the time span between ca. 1650-1150 BCE. The fern Pteridium aquilinum, typical in pasture and marginal areas, which is favored by fire activities also shows a continuous curve for the same period. In Grassee those tendencies are less pronounced; therefore the two charcoal peaks at 1650 and 
$1400 \mathrm{BCE}$ are more difficult to interpret but also seem to be related to subsequent increases in oak and anthropogenic indicators. Particularly since the Final Neolithic, forest pastures in anthropogenically modified forest ecosystems were likely; these pastures likely resulted from the combined effects of wood procurement (construction, burning) and maintenance of areas for livestock husbandry (Rösch, 2013). Considering the weaker evidence for Neolithic settlements at the ABR site, such land use practices seem to have commenced at the beginning of the Bronze Age, especially considering the archaeological record of the MBA. Similar observations were made for pollen profiles from Lake Biber (close to an MBA settlement in Switzerland), where increased abundances of Quercus pollen were interpreted as the result of human promotion of oak species to maintain areas for livestock husbandry (e.g., acorn for pigs) as well as for timber and firewood procurement (Achour-Uster et al., 2001; van der Knaap and Leeuwen, 2001). The higher diversity of taxa in the upper part of ABR SA1 and ABR SA2, with increasing amounts of conifers and Fagus, indicates human impact until the modern period (Vrška et al., 2009).

During the MBA, the use of fire at the ABR site for landscape opening, maintenance and domestic purposes, associated with the combustion of grass as well as wood and charcoals is indicated by the PAH patterns in the corresponding colluvial horizons and by the local archaeological record. The forest ecosystems were anthropogenically modified, and Quercus was promoted, which can be linked to land use practices, such as forest pastures (see Sect. 4.2.3) and wood procurement. The off-site pollen data support the occurrence of oak-dominated forest ecosystems on a regional scale (see Sect. 4.3).

\subsubsection{Arable farming}

Past land use practices in the context of arable farming can be interpreted from different proxies preserved in archaeological remains, colluvial deposits and buried topsoils. These proxies provide information on the presence and spatial distribution of potential arable land (open landscapes), the occurrence of different crop species and related archaeological and pedological structures such as storage facilities and plow marks (e.g., Gnepf-Horisberger and Hämmerle, 2001; Pietsch and Machado, 2014; Rösch et al., 2014a).

With this, phytoliths from buried soils and colluvial deposits are frequently used to decipher past arable farming (e.g., Meister et al., 2017; Weisskopf et al., 2014). At the ABR site, the high proportion of weathered phytoliths, together with the absence of multicellular phytoliths, is an indication of the poor preservation of the assemblages, likely due to a variety of depositional and post-depositional processes (Cabanes et al., 2009; Madella and Lancelotti, 2012). However, some general trends can be noted in the phytolith assemblages: monocotyledonous plants produce more phytoliths than dicotyledons in most cases (Piperno, 2006), but the relatively higher abundance of monocotyledonous morphotypes in combination with the other proxies is likely the result of an open landscape in the area immediately surrounding the ABR site. It is interesting to note that the lowest phytolith concentrations were found in the modern topsoils (Ap) and the highest concentrations in the buried horizons, as the phytolith concentrations usually decrease with soil depth (Meister et al., 2017). The phytolith assemblages from all samples were predominantly composed of phytoliths originating in the leaves and stems of monocotyledonous plants, which include many of the regionally important crop species. As the result of harvesting activities, the inflorescences of these plants were likely removed from the agricultural field, leading to a lower abundance of inflorescence phytoliths in these samples (Dietrich et al., 2019). Particularly in the buried plow horizons (2Apb) of the ABR SA2 profile, relatively high concentrations of phytoliths with simultaneous low abundances of inflorescence compartments indicate an arable field south of the MBA settlement that may have been quickly buried, thus leading to better phytolith preservation and higher concentrations in these horizons (Cabanes et al., 2009). Micromorphology also confirmed a buried plow horizon (2Apb) in profile ABR SA2. So far, MBA plow marks and soil-structural features indicating tillage have not been published for the northwestern Alpine foreland at inland sites. Therefore, the micromorphological analysis of thin sections from a buried plow horizon offers a unique opportunity of identifying prehistoric tillage practices. Evidence of arable farming derived from phytolith analysis is further supported by micromorphological analysis of two thin sections at the 2Apb horizon (ABR SA2), which indicates the use of ards that were widely spread since the Late Neolithic (see Tegtmeier, 1987). Very dusty clay coatings with embedded coarse material (clay-silt-sand coatings) can be related to soil cultivation (Macphail et al., 1990; Usai, 2001), while the occurrence of compacted large (sub)rounded peds may indicate plowing with an ard (see Fig. 6 in Gebhardt, 1999). The occurrence of a nearly rectangular area with inclined bands of alternating coarse and fine material can be caused by the disturbance of ards or plows as described by Lewis (2012); with this, the material is relocated in clods and inclined around $45^{\circ}$ to one side. All relocation features found such as inclined bands, large partially rounded peds and the very dusty clay-sand coatings indicate mixing and slaking and can be interpreted as a result of cultivation (Macphail, 1990). In addition, the frequently occurring charcoal fragments, coprolites and phytoliths, can be related to cultivation. Based on the phytolith and micromorphological data, the agricultural activity at the ABR site is verified; however, the question of which staple crops were used by MBA farmers in the Hegau remains open.

This gap can be filled by the on-site archaeobotanical remains at the ABR site. These remains hold special value, as on- and near-site evidence on MBA crop production in the northwestern Alpine foreland is still scarce (Rösch et al., 
2014a, b, 2015). The cereals typical of the Early and Middle Bronze Age like Hordeum distichon/vulgare, Triticum dicoccum, Triticum monococcum, Triticum aestivum/turgidum and Triticum spelta also occur at the ABR site. A similar spectrum of cereals was found in fire pits at the MBA settlement in Cham-Oberwil (Switzerland) (Gnepf-Horisberger and Hämmerle, 2001); however these fire pits also contained pulses (e.g., broad bean), which were missing at the ABR site. From the observed cereal crop diversity, a sophisticated cropping system, with utilized different soil types, different sowing and harvesting times and a variety of food processing techniques, can be assumed. In the study area, emmer is grown in modern times, preferentially during the summer periods, while spelt, which is resistant to low temperatures, is typically sown in winter. Einkorn and barley are known to be viable as both summer and winter crops. Einkorn, emmer and spelt can easily be stored; all of them require further time-consuming processing (e.g., husking) before consumption in contrast to free-threshing wheat, which however is more vulnerable to storage infestation. The MBA crop diversity allows for a distribution of the agricultural activities throughout the year, which leads to a potentially larger territory being available for crop growing and improves food security. However, the cultivation of various cereal crops requires knowledge and capacities for post-harvest processing of the cereal crops (e.g., drying, roasting, husking) and storing, which are both indicated by the archaeological record. The secondary deposition of heat stones at the ABR site can also be related to MBA food processing. Even though the function of the heat stones is widely discussed, with interpretations including technical applications such as stone breweries and metal processing (Beigel, 2019; Honeck, 2009), they are most commonly considered to be cooking pits for the roasting of cereals and other agrarian products (Lindemann, 2008). Furthermore, post-holes from 10 very small constructions with square or short rectangular shapes at the ABR site are most likely remnants from storage buildings. There is a broad consensus that such constructions are related to arable farming and represent stilted pantries for the storage of food, especially of cereals (Gnepf-Horisberger and Hämmerle, 2001). In general, stilted pantries are frequently observed from MBA sites in the northwestern Alpine foreland, whereas similar structures are significantly in excavations from neighboring regions, such as Bavaria (Höpfer et al., 2021). Statements on the importance of individual cereal species cannot yet be made, since the number of records is still too low, and the hulled wheat species with their very robust glumes are often overrepresented in archaeobotanical records. Leguminous (lens, broad bean and pea) as well as oil and fiber (flax and poppy) crops were also important elements of the Early and Middle Bronze Age agricultural economy of the Alpine foreland (Stika and Heiss, 2013), but they are rarely preserved in charred form and are therefore mostly underrepresented at sites with aerobic soil conditions (Rösch et al., 2014a, 2015). During the Middle Bronze Age, sporadic finds of millet are also known from the study area but did not occur in the record of botanical macro remains of the ABR site. However, the fact that all those crops are missing from the archaeobotanical assemblages of the ABR site cannot be interpreted as their definitive absence in the region's MBA economy. Nevertheless, the occurrence of open landscapes and an MBA arable field, which was cultivated for cereal crop production, is verified and is also supported by the identification of the common MBA crop species. Furthermore, post-harvest processing and storage facilities for cereal crops appeared to be an integral part of the MBA agriculture.

\subsubsection{Livestock husbandry}

The reconstruction of livestock husbandry from sedimentary archives is commonly achieved through the analysis of urease activity or faecal biomarker resulting from past exposure to urea or animal faeces (e.g., Chernysheva et al., 2015; Prost et al., 2017). Both proxies are a suitable marker for the past as they are resistant against weathering (urease-organo-mineral complexes and aromatic molecule structure) and rather immobile in the soil environment and therefore persist in soils over millennia (Bull et al., 1999; Burns et al., 2013; Skujiòs and McLaren, 1968). The comparison of these proxies with the zooarchaeological record of animal bones derived from archaeological features could provide detailed information about past livestock farming practices.

Eutrophication always leads to an input of urea into the soil, and urea may originate from past and recent animal faeces or from the degradation of nucleic acids as part of the soil necromass. However, in greater soil depths, lower levels of currently active microorganisms and urease enzyme activity are expected. Therefore, a higher urease to microbial biomass $\mathrm{C}$ quotient in greater soil depths indicates formerly eutrophicated areas that could be associated with areas of livestock husbandry, such as pastures or livestock shelters. In contrast to other studies, increased levels of urease enzyme activities in soils of the ABR site cannot be solely explained by a relationship to SOC or clay (Taylor et al., 2002). Particularly below $130 \pm 20 \mathrm{~cm}$, other factors must have been responsible for increased urease activities. The past anthropogenic input of urea in relation to livestock husbandry or manuring has been shown in several archaeological studies (e.g., Borisov and Peters, 2017; Chernysheva et al., 2015). Hence, elevated urease $/ \mathrm{C}_{\mathrm{mic}}$ ratios in soil horizons, associated with the MBA land surface or concurrent colluvial horizons, can be interpreted as an anthropogenic input of urea due to land use activities at the ABR site. However, no spatial differences in urease $/ C_{\text {mic }}$ ratios could be observed that would indicate a separation of different land use practices and intensities. Only the lower part of the $2 \mathrm{Bw}$ horizon in profile ABR SA1 had considerably higher values of urease $/ \mathrm{C}_{\text {mic }}$, ratio, suggesting formerly eutrophicated areas and high urease levels in the past. Although the OSL age from the $2 \mathrm{Bw}$ horizon 
showed a last bleaching of mineral grains during the Roman period $(300 \pm 200 \mathrm{CE})$, soil tillage prior to the Roman period is likely for two reasons: first, at ABR SA1, the first phase of sedimentation is dated to the Early Medieval period $(800 \pm 100 \mathrm{CE}, \mathrm{M} 7)$, which means the in situ land surface could have been used during the MBA. Second, ABR SA1 is located less than $40 \mathrm{~m}$ north of ABR SA2, which has a buried plow horizon (2Apb) that is dated to the MBA and indicates related land use activities. At the $\mathrm{ABR}$ site, the increased urease $/ \mathrm{C}_{\text {mic }}$ ratios in MBA soil horizons indicate past input of urea into the soils, which could be associated with land use practices such as livestock husbandry (on fallow land and in forests) and the application of manure to arable fields. However, there is weak evidence of intentional manure application during MBA, and agricultural practices such as livestock farming on long-standing fallow land have more likely contributed to increased urea concentrations (Tserendorj et al., 2021). Whether urea originated from omnivorous or herbivorous livestock cannot be assessed by the analysis of urease enzyme activity.

The analysis of faecal biomarker enables a differentiation between herbivorous and omnivorous animal faeces, which enter the soil via the faeces of past livestock. In previous studies, steroid analyses helped to identify organic manuring in Neolithic soil relicts (Lauer et al., 2014) and in soils surrounding a Roman settlement (Simpson et al., 1999). Hence, the steroid composition of human-influenced soil horizons (buried topsoils, colluvial horizons) should be different from the adjacent subsoils, if such land use was practiced. In the northern surrounding area of the ABR site (ABR W1), $5 \beta$ stanols (e.g., coprostanol, epicoprostanol) were enriched in the M6 horizon and support the interpretation of the MBA deposition of faeces, as indicated by higher levels of past urease enzyme activities. These $5 \beta$-stanols originate mainly from the microbial reduction of $\Delta^{5}$-sterols during omnivorous digestion processes and are related to pig or human faeces in the context of past land use (Birk et al., 2011). The higher levels of $5 \beta$-stanols are further supported by the coprostanol $/$ (coprostanol + epi- $5 \beta$-stigmastanol $) \times 100$ ratio, which was introduced by Leeming et al. (1997) to differentiate between herbivorous and omnivorous faeces. In profile ABR W1, the ratio clearly indicates an input of steroids from omnivorous digestion processes $(>73 \%)$. With increasing soil depth, cholestanone and cholesterol were most abundant at both profiles. Cholesterol is the dominating $\Delta^{5}$ sterol occurring in nearly all eukaryotic cells (Mouritsen and Zuckermann, 2004), while cholestanone is produced by microbial transformation from its sterol precursors. We interpret the higher abundance of source-unspecific sterols and lipids formed during microbial metabolization as the given background composition of steroids of the soil environment with low human influence. In profile ABR SA1, $5 \beta$-stanols were not as dominant as in profile ABR W1, indicating a reduced input of omnivorous faeces. Nevertheless, faecal input by wildlife species, organic manuring and/or occasional pasture on fallow land could have contributed to the occurrence of $5 \beta$-stanols. The latter may have also contributed to increased levels of epi-5 $\beta$-stigmastanol, which mainly originates from herbivorous digestion processes (Derrien et al., 2011). This is in line with the coprostanol $/($ coprostanol + epi-5 $\beta$-stigmastanol $) \times 100$ ratio, pointing to mainly faecal input by herbivores $(<38 \%)$ at the ABR SA1 profile. There, phytosterols, such as $\beta$-sitosterol and stigmastanol, were also more abundant. In the buried subsoil of ABR SA1 (2Bw), source-unspecific steroids, e.g., cholestanone, were dominating the steroidal assemblage, indicating lower anthropogenic influence. The faecal biomarkers show past input of animal faeces in the area surrounding the MBA settlement, which can be associated with the occurrence of omnivorous and herbivorous livestock. North of the settlement site, we identified a dominance of $5 \beta$-stanols, which, together with the results from the charcoal determination, suggests a forest ecosystem dominated by oaks, where mainly pig farming was practiced (see Sect. 4.2.1). Higher levels of plant lipids and herbivorous biomarker in the area south of the settlement site support the presence of arable fields, which could have also been subject to an input of animal faeces during fallow practices or intentional manuring.

Information on different animal species, which were part of the farming practices at the ABR site, can be provided by the determination of animal bones, which were deposited at the MBA settlement. With $79 \%$ of unidentified animal bones from various archaeological pit fillings, the degree of fragmentation is high, which is further indicated by postdepositional bone damage from insects and roots. Acidic weathering of animal bones can be mostly ruled out at the ABR site since the soil milieu is neutral. Hochuli et al. (2001) reported a similar degree of fragmentation of animal bones at an MBA settlement in Switzerland. The taxonomic determination of animal bones, with four to five domestic and five wild species at the ABR site, supports the results of the urease enzymatic activity and faecal biomarker investigations insofar as domestication and livestock husbandry were important at the ABR site during the MBA. The dominance of sheep/goat, pig and cattle species are also observed at MBA settlements sites in southwest Germany (Kokabi, 1990; Köninger, 2006; Stephan, 2016). Nevertheless, the wide range of wildlife species and their share in the total number and weight illustrate that hunting was still important during the MBA. The high percentage of sheep/goat and cattle bones partially contradicts the low evidence of herbivorous faeces by steroid analysis. It is likely that the colluvial profiles were not always congruent with MBA grazing areas. Areas within the MBA settlement and in the east, where the Hepbach River might have formed floodplain forests, could have been suitable for grazing. However, the subdominant abundance of pig bone is consistent with higher concentrations of $5 \beta$-stanols, especially in the north of the ABR site (ABR W1). In combination, the results from the charcoal and animal bone determination, urease enzyme activity and 
faecal biomarker are complementary and suggest a diverse landscape management model with a spatial distribution of livestock practices. North of the MBA settlement, the occurrence of oak-dominated forest ecosystems and the high concentrations of $5 \beta$-stanols are in line with a considerable amount of pig bone from MBA pit fillings and indicate a forest pasture mainly for pig farming and wood procurement. In the south of the ABR site, the higher concentrations of phytoliths with minor amounts of grass phytoliths derived from the floral parts, as well as the occurrence of an MBA plow horizon and the increased input of herbivorous faeces, indicate an open landscape for crop cultivation (arable fields) and livestock husbandry on fallow land and/or manuring with animal faeces.

\subsubsection{Metal processing}

The distribution of heavy metals in soils is influenced by the substrate, $\mathrm{pH}$ value, content of lime and SOC, sedimentation processes and past and modern anthropogenic impact (Young, 2013). These factors must be considered when assessing the natural and anthropogenic accumulations of heavy metals (Henkner et al., 2018b). $\mathrm{Cu}$ and $\mathrm{Zn}$ are major elements of bronze that gained importance during the Metal Ages but had to be traded over long distances due to their limited natural occurrences in the area (Jennings, 2017; Knopf, 2017). Cr and Ni, as secondary components, can also be associated with the production of bronze. $\mathrm{Pb}$ has been used metallurgically since the Roman period, while $\mathrm{Cd}$ and $\mathrm{As}$ are tracers for more recent land use (around $1900 \mathrm{CE}$ ) (Smolders and Mertens, 2013; Völkel, 2003).

The percolation of heavy metals through the soil can be neglected in all profiles of the ABR site since the $\mathrm{pH}$ is always $>7$. The variations in $\mathrm{CaCO}_{3}$ mostly explain the heavy metal patterns for the sediments of the Younger Juranagelfluh and Würm glaciation but not for the basaltic sediments of the Hohenhewen volcano. The natural variation of heavy metals, as indicated by the range between the 25 th and 75 th quartile \pm 1.5 interquartile range, is supported by the analysis of geological background values by the geological state office of Baden-Württemberg (LGRB, 2020). However, a few positive outliers were identified for the different soil substrates. At ABR WA2 and ABR S30, the outliers cannot be further assessed for prehistoric human-land interactions due to lacking age determinations, while the maximum tin values at $\mathrm{ABR}$ SA1 are detected at the colluvial horizon M7, dated to the Roman period. Based on heavy metal contents, which are mostly in the range of natural variation, and their correlation with $\mathrm{CaCO} 3$, an intensive MBA metal processing, which also affects the adjacent sediments, cannot be deduced at the ABR site. The deposited copper ingot, most likely from the eastern Alps (Lutz and Pernicka, 2013), however, indicates that metals were traded over long distances and that the processing and maintaining of tools may have been carried out at the
ABR site but with no detectable effect of heavy metals in the investigated buried and colluvial horizons.

\subsection{Off-site vegetation signals in relation to land use practices at the ABR site}

The two new pollen profiles (Figs. 13 and 14) show close similarities regarding the Bronze Age (2200-800 BCE) human-land interactions in the Hegau. At Grassee and Hartsee, human impact is very weak between 2000 and 1800 BCE. At Grassee, a short period of human impact on the vegetation can be noticed in the 18th century BCE, which subsequently decreases between 1600-1500 BCE. At Hartsee, human influence was high between the 17 th and 15 th century BCE without any intermediate decrease. Both profiles show a very strong human influence between 15001400 BCE, which after that slightly decreases. At Hartsee, human influence is clearly pronounced between 1000 and $800 \mathrm{BCE}$, whereas this influence is absent in the Grassee pollen profile.

The NAP percentages at Grassee and Hartsee, which are a robust indication of human-land interaction, are analogous to other profiles near Lake Constance (Rösch et al., 2021). Especially during the MBA, anthropogenic deforestation appears to be rather similar in the Hegau. In Oberschwaben, the Allgäu (southern Germany), and in the Black Forest (southwest Germany) deforestation is generally weaker, while at Lake Aalkisten in the Kraichgau (southwest Germany) a pronounced deforestation is observed in the EBA and LBA (Rösch et al., 2021).

The comparison of the pollen archives of Grassee and Hartsee with the local records of the ABR site helps to assess the supraregional character of on-site and near-site land use and vegetation changes at MBA settlements in the northwestern Alpine foreland. In both profiles, the percentage of NAP increases from the EBA to the MBA, with a distinct peak between 1500 and $1400 \mathrm{BCE}$. This peak is accompanied by low percentages of Betula, Corylus and Fagus, suggesting that human-land interactions gradually shifted from the lakeshores of Lake Constance (EBA) to areas further inland (MBA). This cannot be interpreted as an abrupt shift in the land use pattern but rather a refined form of agropastoralism, which had its roots in the EBA and continued throughout the MBA in the Hegau. This is also supported by the offsite pollen record with several micro-charcoal peaks, which indicate paleo-fire activities shaping the land cover since $2450 \mathrm{BCE}$, as well as the high concentrations of phytoliths in MBA soil horizons as the result of advanced landscape opening related to local agricultural practices. The pollen curves of Quercus and Fagus clearly alternate corresponding to increasing and decreasing human occupation. Considering the different input pathways of charred archaeobotanical remains, pollen and charcoal, with respect to their catchment area, the pollen spectrum comprises the regional vegetation record of human occupation and adjacent succes- 
sional phases. Even the use of cereals is distinct from onsite archaeobotanical data; "closed" forested landscapes may have hindered the distribution of the off-site pollen of cultivated cereals by the filtering effect. Due to their size (ca. 40 $55 \mu \mathrm{m})$, the spread of the Cerealia-type pollen is hindered if they are not in the immediate surroundings of the depositional environment. Moreover, the pollination of several cereal crops (Triticum, Hordeum) is cleistogamic - this means the flower is closed - which also contributes to a limited pollen spread if no threshing or further crop processing took place near the peat bog.The anthracological data indicate local vegetation and deforestation patterns (colluvial deposits) and human decision-making (fuel procurement). The human impact on vegetation, as recorded in those paleoecological archives, seems to clearly promote the increase of Quercus in the MBA landscape of Hegau. This is in line with the charcoal record of MBA colluvial deposits and fireplaces at the ABR site, which exhibited a strong dominance of Quercus. In the pollen diagram of Hartsee, the Fagus usually decreases after the occurrence of micro-charcoal peaks and is then followed by an increase in Quercus and pollen indicators of agriculture (Triticum-type) and pasture (Plantago lanceolata). Forest pastures for pig farming are indicated at the ABR site, when considering the high occurrence of Quercus in the colluvial deposits and MBA fireplaces as well as the identification of $5 \beta$-stanols and pig bone (see Sect. 4.2.1, 4.2.3). Agricultural indicators are present in both the onsite and near-site colluvial and archaeological archives at the ABR site and in the off-site pollen records. These indicators, as well as indicators from another MBA settlement close to the Hartsee profile (Hald, 2016), clearly underline the regional character of the identified land use practices during the MBA.

\section{Conclusions}

The multi-proxy analysis of archaeological features (on-site), colluvial deposits, buried topsoils (near-site) and peat bogs (off-site) of the Middle Bronze Age in the Hegau (SW Germany) shows how helpful such multi-proxy approaches can be for a refined understanding of past human-land interactions. (i) From the archaeopedological reconstruction of phases of colluvial deposition and on-site and near-site land use practices, we can infer sophisticated land use practices at the Middle Bronze Age settlement site in Anselfingen, which undoubtedly marked the beginning of major colluvial deposition. The land use practices promoted Quercus at the expense of Fagus, the arable farming relied on cultivation of five cereal crops and involved plowing. Livestock husbandry was based on pasture on fallow land and forest pasture for pig farming, while hunting was also part of the MBA economy. (ii) The spatial patterns of the on-site and near-site land use practices revealed that a type of forest management (inc. pig farming) mostly occurred in the surrounding area north of the ABR settlement site, while arable farming was practiced in the south. Based on the differentiation of combustion processes between the settlement and the nearby land use areas, we conclude a wide range of fire application such as domestic fires for cooking, technical applications and ritual practices, as well as fires to open and maintain the land use areas, that differed on a spatial scale. (iii) From the comparison of on-site and near-site vegetation patterns from colluvial deposits and archaeological remains and the off-site vegetation signals from two pollen profiles, we conclude similar patterns of human-induced vegetation change, which characterized the anthropogenic impact in the Hegau on a local and regional scale. The pollen records show that during the Early and Middle Bronze Age, fire played a role in shaping the landscape and that also on a regional scale, anthropogenic activities favored Quercus-dominated forest ecosystems.

In summary, the interdisciplinary approach between soil science, archaeology, archaeobotany and archaeozoology allowed for in-depth insights into the Middle Bronze Age subsistence economy in the Hegau. From the similar patterns of human-induced vegetation change and land use on a local and regional scale, one can infer a characteristic appearance of landscapes in the northwestern Alpine foreland during the Middle Bronze Age. The study also supports the assumption that the Middle Bronze Age in the northwestern Alpine foreland was a period of mainly spatial changes at a regional scale with a shift of settlements from the lakeshore to sites further inland, which was accompanied by corresponding landscape transformations.

Data availability. All data used in the analysis of colluvial deposits and the tables and figures are available at https://datadryad.org/stash/share/ hVuLgYtHXROjtUDhBg9BRgVQ3H4pfL1INAXwzjTnT5E (Scherer et al., 2020).

Supplement. The supplement related to this article is available online at: https://doi.org/10.5194/soil-7-269-2021-supplement.

Author contributions. PK, TK and TS acquired the funding to carry out the study. SaS, BH, TK, TS and PK conceptualized the research experiment and the hypothesis. SaS carried out the soil scientific fieldwork and sampling and most of the data collection, including the analysis of urease activity, microbial biomass carbon and faecal biomarkers. JL and MF performed the OSL dating, BH contributed with data of the local archaeological record, JM and KW analyzed the phytolith assemblages, KD performed the anthracological determination of charcoals, EF investigated the charred archaeobotanical remains, HR analyzed the polycyclic aromatic hydrocarbons, JZ performed the zooarchaeological investigations, and MR, JL and EM contributed with the pollen analysis. SaS and PK prepared the manuscript, and all authors contributed to the inter- 
pretation of the results, to the discussion and to the manuscript in general.

Competing interests. The authors declare that they have no conflict of interest.

Acknowledgements. This study is part of the Collaborative Research Center 1070 ResourceCultures (SFB 1070) at the Eberhard Karls University Tübingen financed by the German Research Foundation (DFG).

We are grateful to many technical assistants and student helpers from the University of Tübingen and the University of Bayreuth who supported the fieldwork and laboratory work, namely Rita Mögenburg, Karin Söllner, Andrey Rodionov, Simon Degler, Astrid Paul, Philipp Garbe, and Daniel Greulich. We thank Thomas van den Berg (Chromtech GmbH, Bad Camberg, Germany) for his technical support in maintaining the GC-MS/MS system. We also thank Marco Nicolì from the SFB 1070 for the archaeobotanical determination of an additional 30 charred grains. We are especially grateful to Jürgen Hald and Björn Schleicher from the Archaeological Service of the District of Constance for their tremendous support in the field. We want to thank Siah Beattie for her help on editing the manuscript and improving the reading flow.

Financial support. This research has been funded by the Deutsche Forschungsgemeinschaft (DFG, German Research Foundation) within the Collaborative Research Center SFB 1070 "ResourceCultures"-SFB1070/2.

Review statement. This paper was edited by Jeffrey Homburg and reviewed by Steven Shelley and one anonymous referee.

\section{References}

Achour-Uster, C., Kunz, J., and Brombacher, C.: Die mittelbronzezeitliche Siedlungsstelle von Birmensdorf-Stoffel: Grabungen 1995-1996, Zürcher Archäologie, 87 pp., 2001.

Ad-hoc-AG Boden: Bodenkundliche Kartieranleitung (KA 5) der Staatlichen Geologischen Dienste und der Bundesanstalt für Geowissenschaften und Rohstoffe, mit 103 Tabellen und 31 Listen, Schweizerbart, 2005.

Albert, R. M.: Study of ash layers through phytolith analyses from the Middle Paleolithic levels of Kebara and Tabun caves, Universitat de Barcelona, Barcelona, Spain, 226 pp., http://hdl.handle. net/2445/42640 (last access: 8 June 2021), 1999.

Albert, R. M., Lavi, O., Estroff, L., Weiner, S., Tsatskin, A., Ronen, A., and Lev-Yadun, S.: Mode of occupation of Tabun Cave, Mt Carmel, Israel during the Mousterian Period: a study of the sediments and phytoliths, J. Archaeol. Sci., 26, 1249-1260, https://doi.org/10.1006/jasc.1999.0355, 1999.

Anderson, J. P. E. and Domsch, K. H.: A physiological method for the quantitative measurement of microbial biomass in soils, Soil Biol. Biochem., 10, 215-221, https://doi.org/10.1016/00380717(78)90099-8, 1978.
Bailey, R. M. and Arnold, L. J.: Statistical modelling of single grain quartz De distributions and an assessment of procedures for estimating burial doses, Quaternary Sci. Rev., 25, 2475-2502, https://doi.org/10.1016/j.quascirev.2005.09.012, 2006.

Ball, T. B., Gardner, J. S., and Anderson, N.: Identifying inflorescence phytoliths from selected species of wheat (Triticum monococcum, T. dicoccon, T. dicoccoides, and T. aestivum) and barley (Hordeum vulgare and H. spontaneum) (Gramineae), Am. J. Bot., 86, 1615-1623, https://doi.org/10.2307/2656798, 1999.

Bärnthol, R.: Nieder- und Mittelwald in Franken: Waldwirtschaftsformen aus dem Mittelalter, Fränkisches Freilandmuseums, Bad Windsheim, Germany, 2003.

Bastin, B.: Essai de définition d'une terminologie précise applicable au commentaire des diagrammes polliniques se rapportant au quaternaire, B. Soc. Roy. Bot. Belg., 112, 7-12, 1979.

Beigel, R.: Ein Michelsberger Teilskelett und metallzeitliche Gargruben: Das Gewerbegebiet von Burgbernheim als Fallbeispiel zur Archäologie im Gipskarst, Beitr. Arch. Mittelfranken, 9, 95130, 2019.

Bekker, R. M. and Cappers, R. T. J.: Digitale Zadenatlas Van Nederland/Digital Seed Atlas of the Netherlands, Groningen Instituut voor Archeologie, Groningen, The Netherlands, 502 pp., 2006.

Berglund, B. E.: Handbook of Holocene Palaeoecology and Palaeohydrology, John Wiley and Sons, 19, 7, https://doi.org/10.1002/jqs.3390010111, 1986.

Birk, J. J., Teixeira, W. G., Neves, E. G., and Glaser, B.: Faeces deposition on Amazonian Anthrosols as assessed from 5 $\beta$-stanols, J. Archaeol. Sci., 38, 1209-1220, https://doi.org/10.1016/j.jas.2010.12.015, 2011.

Birk, J. J., Dippold, M., Wiesenberg, G. L., and Glaser, B.: Combined quantification of faecal sterols, stanols, stanones and bile acids in soils and terrestrial sediments by gas chromatography-mass spectrometry, J. Chromatogr. A, 1242, 110, https://doi.org/10.1016/j.chroma.2012.04.027, 2012.

Bläsing, M., Kistler, M., and Lehndorff, E.: Emission fingerprint of inland navigation vessels compared with road traffic, domestic heating and ocean going vessels, Org. Geochem., 99, 1-9, https://doi.org/10.1016/j.orggeochem.2016.05.009, 2016.

Bogaard, A.: The nature of early farming in central and south-east Europe, Doc. Praehist., 31, 49-58, https://doi.org/10.4312/dp.31.4, 2004.

Bohn, U., Neuhäusl, R., Gollub, G., Hettwer, C., Neuhäuslová, Z., and Raus, T.: Map of the Natural Vegetation of Europe, Scale 1:2 500 000, Landwirtschaftsverlag, Munster, Germany, 2003.

Borisov, A. V. and Peters, S.: Geoarchäologische Untersuchungen in Karbadinka 2 und 3, in: Landschaftsarchäologie im Nordkaukasus, Archäologie in Eurasien, edited by: Reinhold, S., Korobov, D. A., and Belinksij, A. B., 71-94, 2017.

Brestrich, W.: Die mittel- und spätbronzezeitlichen Grabfunde auf der Nordstadtterrassevon Singen am Hohentwiel, Forschungen und Berichte zur Vor- und Frühgeschichte in BadenWürttemberg, 419 pp., 1998.

Brown, D. A.: Prospects and limits of a phytolith key for grasses in the central United States, J. Archaeol. Sci., 11, 345-368, https://doi.org/10.1016/0305-4403(84)90016-5., 1984.

Bull, I. D., Simpson, I. A., Dockrill, S. J., and Evershed, R. P.: Organic geochemical evidence for the origin of ancient anthropogenic soil deposits at Tofts Ness, Sanday, Orkney, 
Org. Geochem., 30, 535-556, https://doi.org/10.1016/S01466380(99)00020-0, 1999.

Budzinski, H., Jones, I., Bellocq, J., Pierard, C., and Garrigues, P. H.: Evaluation of sediment contamination by polycyclic aromatic hydrocarbons in the Gironde estuary, Mar. Chem., 58, 85-97, https://doi.org/10.1016/S0304-4203(97)00028-5, 1997.

Burns, R. G., DeForest, J. L., Marxsen, J., Sinsabaugh, R. L., Stromberger, M. E., Wallenstein, M. D., Weintraub, M. N., and Zoppini, A.: Soil enzymes in a changing environment: current knowledge and future directions, Soil Biol. Biochem., 58, 216234, https://doi.org/10.1016/j.soilbio.2012.11.009, 2013.

Cabanes, D., Burjachs, F., Expósito, I., Rodríguez, A., Allué, E., Euba, I., and Vergès, J. M.: Formation processes through archaeobotanical remains: The case of the Bronze Age levels in El Mirador cave, Sierra de Atapuerca, Spain, Quatern. Int., 193, 160-173, https://doi.org/10.1016/j.quaint.2007.08.002, 2009.

Chernysheva, E. V., Korobov, D. S., Khomutova, T. E., and Borisov, A. V.: Urease activity in cultural layers at archaeological sites, J. Archaeol. Sci., 57, 24-31, https://doi.org/10.1016/j.jas.2015.01.022, 2015.

Cunningham, A. and Wallinga, J.: Realizing the potential of fluvial archives using robust OSL chronology, Quat. Geochronol., 12, 98-106, https://doi.org/10.1016/j.quageo.2012.05.007, 2012.

Derrien, M., Jarde, E., Gruau, G., and Pierson-Wickmann, A.: Extreme variability of steroid profiles in cow faeces and pig slurries at the regional scale: implications for the use of steroids to specify faecal pollution sources in waters, J. Agr. Food Chem., 59, 7294-7302, https://doi.org/10.1021/jf201040v, 2011.

Dieckmann, B.: Siedlungen und Umwelt der Bronzezeit am Federsee und im westlichen Bodenseegebiet, in: Mensch und Umwelt in der Bronzezeit Europas, edited by: Hänsel, B., 373-394, 1998.

Dietrich, L., Meister, J., Dietrich, O., Notroff, J., Kiep, J., Heeb, J., Beuger, A., and Schütt, B.: Cereal processing at Early Neolithic Göbekli Tepe, southeastern Turkey, PloS One, 14, e0215214, https://doi.org/10.1371/journal.pone.0215214, 2019.

Don, A., Scholten, T., and Schulze, E. D.: Conversion of cropland into grassland: Implications for soil organic-carbon stocks in two soils with different texture, J. Plant Nutr. Soil Sc., 172, 53-62, https://doi.org/10.1002/jpln.200700158, 2009.

Dotterweich, M.: The history of soil erosion and fluvial deposits in small catchments of central Europe: deciphering the long-term interaction between humans and the environment - a review, Geomorphology, 101, 192-208, https://doi.org/10.1016/j.geomorph.2008.05.023, 2008.

Dreibrodt, S., Nelle, O., Lütjens, I., Mitusov, A., Clausen, I., and Bork, H. R.: Investigations on buried soils and colluvial layers around Bronze Age burial mounds at Bornhöved (northern Germany): an approach to test the hypothesis of "landscape openness" by the incidence of colluviation, Holocene, 19, 487-497, https://doi.org/10.1177/0959683608101397, 2009.

Dreibrodt, S., Lomax, J., Nelle, O., Lubos, C., Fischer, P., Mitusov, A., Reiss, S., Radtke, U., Nadeau, M., Meiert Grootes, P., and Bork, H. R.: Are mid-latitude slopes sensitive to climatic oscillations? Implications from an Early Holocene sequence of slope deposits and buried soils from eastern Germany, Geomorphology, 122, 351-369, https://doi.org/10.1016/j.geomorph.2010.05.015, 2010a.

Dreibrodt, S., Lubos, C., Terhorst, B., Damm, B., and Bork, H.R.: Historical soil erosion by water in Germany: Scales and archives, chronology, research perspectives, Quatern. Int., 222, 80-95, https://doi.org/10.1016/j.quaint.2009.06.014, 2010b.

Eberhardt, E., Schad, P., Berner, T., Lehmann, C., Walthert, L., and Pietsch, D.: Ableitungsschlüssel KA5 (2005) nach WRB (2007), Bundesanstalt für Geowissenschaften und Rohstoffe (BGR), Hannover, Germany, 2014.

Edgeworth, M., Richter, D., Waters, C., Haff, P., Neal, C., and Price, S. J.: Diachronous beginnings of the Anthropocene: The lower bounding surface of anthropogenic deposits, Anthropocene Review, 2, 33-58, https://doi.org/10.1177/2053019614565394, 2015.

Ehrle, J., Hald, J., and Höpfer, B.: Zehn Jahre Rettungsgrabung im Kieswerk Kohler bei Anselfingen: ein Resümee, in: Archäologische Ausgrabungen in Baden-Württemberg 2017, 44-49, 2018.

Ellis, E. C.: Anthropogenic transformation of the terrestrial biosphere, Philos. T. Roy. Soc. A, 369, 1010-1035, https://doi.org/10.1098/rsta.2010.0331, 2011.

Ellis, E. C., Kaplan, J. O., Fuller, D. Q., Vavrus, S., Goldewijk, K. K., and Verburg, P. H.: Used planet: A global history, P. Natl. Acad. Sci. USA, 110, 7978-7985, https://doi.org/10.1073/pnas.1217241110, 2013.

Eusterhues, K., Lechterbeck, J., Schneider, J., and Wolf-Brozio, U.: Late-and Post-Glacial evolution of Lake Steisslingen (I): Sedimentary history, palynological record and inorganic geochemical indicators, Palaeogeogr. Palaeocl., 187, 341-371, https://doi.org/10.1016/S0031-0182(02)00486-8, 2002.

Galbraith, R. F., Roberts, R. G., Laslett, G. M., Yoshida, H., and Olley, J. M.: Optical dating of single and multiple grains of quartz from Jinmium rock shelter, northern Australia: Part I, experimental design and statistical models, Archaeometry, 41, 339-364, https://doi.org/10.1111/j.1475-4754.1999.tb00987.x, 1999.

Garscha, F.: Welschingen-Neuhausen A. Engen, Fundberichte aus Baden-Württemberg, 360 pp., 1936.

Gebhardt, A.: Micromorphological Analysis of Soil Structure Modifications Caused by Different Cultivation Implements, in: Prehistory of Agriculture, edited by: Anderson, P. C., Cotsen Institute of Archaeology Press, 260-266, https://doi.org/10.2307/j.ctvhhhg2j.30, 1999.

Geyer, O. F., Gwinner, M. P., Geyer, M., Nitsch, E., and Simon, T.: Geologie von Baden-Württemberg, 627 pp., Germany, 2011.

Gnepf-Horisberger, U. and Hämmerle, S.: Cham-Oberwil, Hof (Kanton Zug): Befunde und Funde aus der Glockenbecherkultur und Bronzezeit (Antiqua), Archäologie Schweiz, Basel, Switzerland, 166 pp., 2001.

Hald, J.: Weitere Ausgrabungen im bronze- bis merowingerzeitlichen Siedlungsareal von Ehingen, in: Archäologische Ausgrabungen in Baden-Württemberg 2014, 250-253, 2015.

Hald, J.: Siedlungsbefunde der Bronze- und Eisenzeit bei Bietingen, in: Archäologische Ausgrabungen in Baden-Württemberg 2015, 107-110, 2016.

Hald, J.: Langbauten in der Kiesgrube Kohler bei Anselfingen?, in: Archäologische Ausgrabungen in Baden-Württemberg 2019, 94-96, 2020.

Hald, J. and Kramer, W.: Archäologische Schätze im Kreis Konstanz, Greuter, 2011.

Hald, J., Häußler, G., and Höpfer, B.: Neue archäologische Ausgrabungen in der eisenzeitlichen Siedlung von Welschingen, 
Flur "Guuhaslen", in: Archäologische Ausgrabungen in BadenWürttemberg 2014, 120-123, 2015.

Henkner, J., Ahlrichs, J. J., Downey, S., Fuchs, M., James, B. R., Knopf, T., Scholten, T., Teuber, S., and Kühn, P.: Archaeopedology and chronostratigraphy of colluvial deposits as a proxy for regional land use history (Baar, southwest Germany), Catena, 155, 93-113, https://doi.org/10.1016/j.catena.2017.03.005, 2017.

Henkner, J., Ahlrichs, J., Fischer, E., Fuchs, M., Knopf, T., Rösch, M., Scholten, T., and Kühn, P.: Land use dynamics derived from colluvial deposits and bogs in the Black Forest, Germany, J. Plant Nutr. Soil Sc., 181, 240-260, https://doi.org/10.1002/jpln.201700249, 2018b.

Hochuli, S., Schibler, J., and Veszeli, M.: Zur Erforschung der Bronzezeit im Kanton Zug, in: Cham-Oberwil, Hof (Kanton Zug): Befunde und Funde aus der Glockenbecherkultur und Bronzezeit, edited by: Gnepf-Horisberger, U. and Hämmerle, S., 181-194, 2001.

Honeck, M.: Nichts als heiße Steine? Zur Deutung der Brenngruben der späten Bronzezeit und frühen Eisenzeit in Deutschland, Univ. Forsch. Prähist. Arch., 166 pp., 2009.

Hölzer, A. and Hölzer, A.: Paläoökologische und siedlungsgeschichtliche Untersuchungen im Seewadel bei Singen (Hegau), Ber. Römisch-German. Kommission, 309-333, 1990.

Honig, P.: Studien zur bronzezeitlichen Keramikentwicklung am Beispiel der Siedlungskeramik der Windsheimer Bucht und des süddeutschen Donauraumes, in: Arbeiten zur Archäologie Süddeutschlands, 22 pp., 2008.

Hopert, S., Schlichtherle, H., Schöbel, G., Spatz, H., and Walter, P.: Der "Hals bei Bodman": Eine Höhensiedlung auf dem Bodanrück und ihr Verhältnis zu den Ufersiedlungen des Bodensees, in: Regensburger Beitrag Prähistorische Archäologie, 91-154, 1998.

Höpfer, B.: Früh-/mittelbronzezeitliche Siedlungsspuren aus Weiterdingen, Lkrs. Konstanz, in: Fundberichte aus Baden-Württemberg, 555-577, https://doi.org/10.11588/fbbw.2014.1.44482, 2014.

Höpfer, B., Rottler, S., Vogt, R., and Knopf, T.: Bronzezeit im Hinterland des Bodensees: Siedlungsreste und Kolluvien aus Bodman, in: Fundberichte aus Baden-Württemberg, 53-76, 2016.

Höpfer, B., Deckers, K., Scherer, S., Scholten, T., Kühn, P., and Knopf, T.: Mittelbronzezeitliche Siedlungsfunde aus EngenAnselfingen (Lkr. Konstanz, Baden-Württemberg): erste Einblicke in Struktur und Organisation der Siedlung, in: Elemente bronzezeitlicher Siedlungslandschaften, Studien zur nordeuropäischen Bronzezeit, edited by: Willroth, K.-H., in press, 2021.

IUSS Working Group WRB: World reference base for soil resources 2014, update 2015, International soil classification system for naming soils and creating legends for soil maps, World soil resources reports No. 106, available at: http://www.fao.org/ 3/a-i3794en.pdf (last access: 14 June 2021), 2015.

Jacomet, S.: Prähistorische Getreidefunde, Eine Anleitung zur Bestimmung prähistorischer Gersten- und Weizenfunde, Basel, Switzerland, 70 pp., 1987.

Jacomet, S., Christoph, B., and Dick, M.: Archäobotanik am Zürichsee, Ackerbau, Sammelwirtschaft und Umwelt von neolithischen und bronzezeitlichen Seeufersiedlungen im Raum Zürich, Ergebnisse von Untersuchungen pflanzlicher Makroreste der Jahre 1979-1988, in: Berichte der Zürcher Denkmalpflege/Monographien, 348 pp., 1989.
Jansen, D. and Nelle, O.: The Neolithic woodlandarchaeoanthracology of six Funnel Beaker sites in the lowlands of Germany, J. Archaeol. Sci., 51, 154-163, https://doi.org/10.1016/j.jas.2012.10.024, 2014.

Jansen, B. and Wiesenberg, G. L. B.: Opportunities and limitations related to the application of plant-derived lipid molecular proxies in soil science, SOIL, 3, 211-234, https://doi.org/10.5194/soil-3211-2017, 2017.

Jennings, B.: Late Bronze Age exchange and interaction in the northern Circum-Alpine region: not only across the Alps, in: Inter-regional contacts during the first millenium BC in Europe, edited by: Jennings, B. and Trefny, M., 24, Pilsen, Czech Republic, 2017.

Kadereit, A., Kühn, P., and Wagner, G. A.: Holocene relief and soil changes in loess-covered areas of southwestern Germany: The pedosedimentary archives of Bretten-Bauerbach (Kraichgau), Quatern. Int., 222, 96-119, https://doi.org/10.1016/j.quaint.2009.06.025, 2010.

Kandeler, E. and Gerber, H.: Short-term assay of soil urease activity using colorimetric determination of ammonium, Biol. Fert. Soils, 6, 68-72, https://doi.org/10.1007/BF00257924, 1988.

Kappenberg, A., Braun, M., Amelung, W., and Lehndorff, E.: Fire condensates and charcoals: Chemical composition and fuel source identification, Org. Geochem., 130, 43-50, https://doi.org/10.1016/j.orggeochem.2019.01.009, 2019.

Katz, O., Cabanes, D., Weiner, S., Maeir, A. M., Boaretto, E., and Shahack-Gross, R.: Rapid phytolith extraction for analysis of phytolith concentrations and assemblages during an excavation: an application at Tell es-Safi/Gath, Israel, J. Archaeol. Sci., 37, 1557-1563, https://doi.org/10.1016/j.jas.2010.01.016, 2010.

Kellner-Depner, C.: Die Latènesiedlung von Anselfingen im Hegau, in: Fundberichte aus Baden-Württemberg, 103-200, 2016.

Kittel, P.: The prehistoric human impact on slope development at the archaeological site in Smólsk (Kuyavian Lakeland), Bull. Geogr. Phys. Geogr. Ser., 8, 107-122, https://doi.org/10.1515/bgeo2015-0009, 2015.

Knopf, T.: Ressourcennutzung und Umweltverhalten prähistorischer Bauern, Eine Analyse archäologischer und ethnographischer Untersuchungen, RessourcenKulturen, Tübingen University Press, Tübingen, Germany, 2017.

Kokabi, M.: Ergebnisse der osteologischen Untersuchungen an den Knochenfunden von Hornstaad im Vergleich zu anderen Feuchtbodenfundkomplexen Südwestdeutschlands, in: Bericht der Römisch-Germanischen Kommission, 145-160, 1990.

Köninger, J.: Die frühbronzezeitlichen Ufersiedlungen von Bodman-Schachen I - Befunde und Funde aus den Tauchsondagen 1982-1984 und 1986, in: Siedlungsarchäologie im Alpenvorland VIII, Forschungen und Berichte zur Vor- und Frühgeschichte in Baden-Württemberg, 85 pp., 2006.

Köninger, J.: Bronze Age lacustrine settlements in the CircumAlpine region: chronology, architectural styles, occupational patterns, and much more, in: The end of the Lake-Dwellings in the Circum-Alpine Region, edited by: Menotti, F., United Kingdom, 15-67, 2015.

Kraft, G.: Funde aus einer Kiesgrube bei Welschingen (Hegau), in: Fundberichte aus Baden-Württemberg, 211-213, 1928.

Krause, R., Christoforidis, A., Kromer, B., Pernicka, E., and Shroter, P.: Die endneolithischen und frühbronzezeitlichen Grabfunde auf der Nordstadtterrasse von Singen am Hohentwiel, 
in: Forschungen und Berichte zur Vor- und Frühgeschichte in Baden-Württemberg, 32 pp., 1988.

Krumland, J.: Die bronzezeitliche Siedlungskeramik zwischen Elsaß und Böhmen, in: Studien zur Formenkunde und Rekonstruktion der Besiedlungsgeschichte in Nord- und Südwürttemberg, Internationale Archäologie, 49 pp., 1998.

Kühn, P., Lehndorff, E., and Fuchs, M.: Late Pleniglacial to Holocene Pedogenesis and Formation of Colluvial Deposits in Central Europe (Gambach, Germany), Catena, 154, 118-135, 2017.

Lang, A.: Phases of soil erosion-derived colluviation in the loess hills of South Germany, Catena, 51, 209-221, https://doi.org/10.1016/S0341-8162(02)00166-2, 2003.

Lauer, F., Prost, K., Gerlach, R., Pätzold, S., Wolf, M., Urmersbach, S., Lehndorff, E., Eckmeier, E., and Amelung, W.: Organic fertilization and sufficient nutrient status in prehistoric agriculture? - Indications from multi-proxy analyses of archaeological topsoil relicts, PloS One, 9, 1-19, https://doi.org/10.1371/journal.pone.0106244, 2014.

Lechterbeck, J.: "Human Impact" oder "Climatic Change"? Zur Vegetationsgeschichte des Spätglazials und Holozäns in hochauflösenden Pollenanalysen laminierter Sedimente des Steisslinger Sees (Südwestdeutschland), Institut und Museum für Geologie und Paläontologie der Universität Tübingen, Tübingen, Germany, 25 pp., 2001.

Leeming, R., Ball, A., Ashbolt, N., and Nichols, P.: Using faecal sterols from humans and animals to distinguish faecal pollution in receiving waters, Water Res., 30, 2893-2900, https://doi.org/10.1016/S0043-1354(96)00011-5, 1996.

Lehndorff, E. and Schwark, L.: Biomonitoring of air quality in the Cologne Conurbation using pine needles as a passive sampler - Part II: polycyclic aromatic hydrocarbons (PAH), Atmos. Environ., 38, 3793-3808, https://doi.org/10.1016/j.atmosenv.2004.03.065, 2004.

Lehndorff, E. and Schwark, L.: Biomonitoring airborne parent and alkylated three-ring PAHs in the Greater Cologne Conurbation I: Temporal accumulation patterns, Environ. Pollut., 157, 13231331, https://doi.org/10.1016/j.envpol.2008.11.037, 2009.

Lewis, H.: Investigating ancient arable farming, An experimental and soil micromorphological study, British Archaeological Reports, Oxford, UK, 118 pp., 2012.

LGRB: Regierungspräsidium Freiburg, Landesamt für Geologie, Rohstoffe und Bergbau Baden-Württemberg: WMS LGRB-BW HW_GEO: Geogene Grundgehalte (Hintergrundwerte) in petrogeochemischen Einheiten von Baden-Württemberg 1:300 000, Landesamt für Geologie, Rohstoffe und Bergbau BadenWürttemberg (LGRB), Freiburg, Germany, available at: https: //maps.lgrb-bw.de (last access: 14 June 2021), 2020.

Lindemann, M.: Gargruben, eine Erklärung von eingetieften Feuerstellen?, in: Experimentelle Archäologie in Europa, 49-65, 2008.

Lutz, J. and Pernicka, E.: Prehistoric copper from the Eastern Alps, Open Journal of Archaeometry, 1, 122-127, https://doi.org/10.4081/arc.2013.e25, 2013.

Lyman, R. L.: Quantitative units and terminology in zooarchaeology, Am. Antiquity, 59, 36-71, https://doi.org/10.2307/3085500, 1994.

Macphail, R. I.: Soil history and micromorphology, in: Brean Down Excavations 1983-1987, Microfiche, English Heritage Archaeological Report No. 15, edited by: Bell, M., Historic Buildings and Monuments Commission for England, London, UK, 187196, 1990.

Macphail, R. I., Courty, M. A., and Gebhardt, A.: Soil micromorphological evidence of early agriculture in north-west Europe, World Archaeol., 22, 53-69, https://doi.org/10.1080/00438243.1990.9980129, 1990.

Madella, M. and Lancelotti, C.: Taphonomy and phytoliths: A user manual, Quatern. Int., 275, 76-83, https://doi.org/10.1016/j.quaint.2011.09.008 2012.

Madella, M., Alexandre, A., and Ball, T.: International code for phytolith nomenclature 1.0, Ann. Bot.-London, 96, 253-260, https://doi.org/10.1093/aob/mci172, 2005.

Meister, J., Krause, J., Müller-Neuhof, B., Portillo, M., Reimann, T., and Schütt, B.: Desert agricultural systems at EBA Jawa (Jordan): Integrating archaeological and paleoenvironmental records, Quatern. Int., 434, 33-50, https://doi.org/10.1016/j.quaint.2015.12.086, 2017.

Menotti, F.: "The missing period": middle bronze age lakedwellings in the Alps, Archaeopress, United Kingdom, 184 pp., 2001.

Menotti, F.: Cultural response to environmental change in the Alpine lacustrine regions: The displacement model, Oxford J. Archaeol., 22, 375-396, https://doi.org/10.1046/j.14680092.2003.00194.x, 2003.

Merkt J. and Streif H.: Stechrohr-Bohrgeräte für limnische und marine Lockersedimente, in: Geologisches Jahrbuch, 137-148, 1970.

Miller, B. A. and Juilleret, J.: The colluvium and alluvium problem: Historical review and current state of definitions, Earth-Sci. Rev., 209, 1-22, https://doi.org/10.1016/j.earscirev.2020.103316, 2020.

Mosandl, R. and Abt, A.: Waldbauverfahren in Eichenwäldern gestern und heute, in: AFZ-Der Wald, 28-32, 2016.

Mouritsen, O. G. and Zuckermann, M. J.: What's so special about cholesterol?, Lipids, 39, 1101-1113, https://doi.org/10.1007/s11745-004-1336-x, 2004.

Murray, A. S. and Wintle, A. G.: Luminescence dating of quartz using an improved single-aliquot regenerative-dose protocol, Radiat. Meas., 32, 57-73, https://doi.org/10.1016/S13504487(99)00253-X, 2000.

Murray, A. S. and Wintle, A. G.: The single aliquot regenerative dose protocol: potential for improvements in reliability, Radiat. Meas., 37, 377-381, https://doi.org/10.1016/S13504487(03)00053-2, 2003.

Nam, J. J., Thomas, G. O., Jaward, F. M., Steinnes, E., Gustafsson, O., and Jones, K. C.: PAHs in background soils from Western Europe: Influence of https://doi.org/10.1016/j.chemosphere.2007.08.010, 2018.

Nölte, J.: ICP-Emissionsspektrometrie für Praktiker: Grundlagen, Methodenentwicklung, Anwendungsbeispiele, Wiley-VCH, 2002.

Pietsch, D. and Kühn, P.: Buried soils in the context of geoarchaeological research - two examples from Germany and Ethiopia, Archaeol. Anthrop. Sci., 9, 1571-1583, https://doi.org/10.1007/s12520-014-0180-9, 2017.

Pietsch, D. and Machado, M. J.: Colluvial deposits-proxies for climate change and cultural chronology, A case study from Tigray, Ethiopia, Z. Geomorphol., 58, 119-136, https://doi.org/10.1127/0372-8854/2012/S-00114, 2014. 
Piperno, D. R.: Phytoliths: A Comprehensive Guide for Archaeologists and Palaeoecologists, Rowman Altamira, 2006.

Ponomarenko, E. V., Ershova, E. G., Stashenkov, D. A., Ponomarenko, D. S., and Kochkina, A. F.: Tracing land use history using a combination of soil charcoal and soil pollen analysis: An example from colluvial deposits of the Middle Volga region, J. Archaeol. Sci., 31, 2-12, https://doi.org/10.1016/j.jasrep.2020.102269, 2020.

Poręba, G., Śnieszko, Z., Moska, P., and Mroczek, P.: Deposits of Neolithic water soil erosion in the loess region of the Małopolska Upland (S Poland) - A case study of the settlement micro-region in Bronocice, Quatern. Int., 502, 45-59, https://doi.org/10.1016/j.quaint.2018.09.018, 2019.

Portillo, M., Kadowaki, S., Nishiaki, Y., and Albert, R. M.: Early Neolithic household behavior at Tell Seker al-Aheimar (Upper Khabur, Syria): A comparison to ethnoarchaeological study of phytoliths and dung spherulites, J. Archaeol. Sci., 42, 107-118, https://doi.org/10.1016/j.jas.2013.10.038, 2014.

Prost, K., Birk, J. J., Lehndorff, E., Gerlach, R., and Amelung, W.: Steroid biomarkers revisited - Improved source identification of faecal remains in archaeological soil material, PloS One, 12, 130, https://doi.org/10.1371/journal.pone.0164882, 2017.

Ramsey, C. B.: Bayesian analysis of radiocarbon dates, Radiocarbon, 51, 337-360, https://doi.org/10.1017/S0033822200033865, 2009.

Redman, C. L.: Human impact on ancient environments, Arizona University Press, 1999.

Reimer, P. J., Bard, E., Bayliss, A., Beck, J. W., Blackwell, P. G., Ramsey, C. B., and Grootes, P. M.: IntCal13 and Marine13 radiocarbon age calibration curves 0-50000 years cal BP, Radiocarbon, 55, 1869-1887, https://doi.org/10.2458/azu_js_rc.55.16947, 2013.

Rigert, E., Stehrenberger, T., Rentzel, P., and Joos, M.: Tägerwilen Hochstross: Dörfer und Gehöfte der Bronze- und Eisenzeit, in: A7 - Ausfahrt Archäologie, Prospektion und Grabungen im Abschnitt Schwaderloh-Landesgrenze, edited by: Rigert, E., Archäologie im Thurgau, 71-88, 2001.

Rösch, M.: New approaches to prehistoric land-use reconstruction in south-western Germany, Veg. Hist. Archaeobot., 5, 65-79, https://doi.org/10.1007/BF00189436, 1996.

Rösch, M.: Der Mensch als landschaftsprägender Faktor des westlichen Bodenseegebietes seit dem späten Atlantikum, in: Eiszeitalter und Gegenwart, 19-29, 1987.

Rösch, M.: Land use and food production in Central Europe from the Neolithic to the Medieval period: Change of landscape, soils and agricultural systems according to archaeobotanical data, in: Economic Archaeology: From Structure to Performance in $\mathrm{Eu}-$ ropean Archaeology, edited by: Kerig, T. and Zimmermann, A., 109-128, 2013.

Rösch, M., Kleinmann, A., Lechterbeck, J., and Wick, L.: Botanical off-site and on-site data as indicators of different land use systems: a discussion with examples from Southwest Germany, Veg. Hist. Archaeobot., 23, 121-133, https://doi.org/10.1007/s00334014-0477-8, 2014a.

Rösch, M., Fischer, E., Kleinmann, A., Lechterbeck, J., Tserendorj, G., and Wick, L.: Bronzezeitliche Landnutzung im diachronen Vergleich - Fallbeispiele aus Südwestdeutschland, in: Ressourcen und Rohstoffe in der Bronzezeit, Arbeitsberichte zur Bodendenkmalpflege in Brandenburg, edited by: Nessel, B. Heske, I., and Brandherm, D., 26 pp., 2014b.

Rösch, M., Fischer, E., Lechterbeck, J., Kleinmann, A., Sillmann, M., Tserendorj, G., and Wick, L.: Bronze Age Land Use and Food Production in Southwest Germany in Light of Botanical On-Site and Off-Site Data, in: The Third Food Revolution? Setting the Bronze Age Table: Common Trends in Economic and Subsistence Strategies in Bronze Age Europe, Human Developments in Landscapes, edited by: Kneisel, J., Dal Corso, M., Kirleis, W., Scholz, H., Tylor, N., and Tiedtke, V., Universitätsforschungen zur Prähistorischen Archäologie, 201-219, 2015.

Rösch, M., Feger, K.-H., Fischer, E., Hinderer, M., Kämpf, L., Kleinmann, A., Lechterbeck, J., Marinova, E., Schwalb, A., Tserendorj, G., and Wick, L.: How changes of past vegetation and human impact are documented in lake sediments: Paleoenvironmental research in Southwestern Germany - a review, in: Limnogeology: Progress, challenges and opportunities: A tribute to Elizabeth Gierlowski-Kordesch, Syntheses in Limnogeology, edited by: Rosen, M. R., Park-Boush, L., Finkelstein, D. B., and Pueyo, S. P., Springer, 2021.

Scherer, S., Höpfer, B., Deckers, D., Fischer, E., Fuchs, M., Kandeler, E., Lechterbeck, J., Lehndorff, E., Lomax, J., Marhan, S., Marinova, M., Meister, J., Poll, C., Rahimova, H., Rösch, M., Wroth, K., Zastrow, J., Knopf, T., Scholten, T., and Kühn, P.: Data from: Middle Bronze Age land use practices in the northwestern Alpine foreland - A multi-proxy study of colluvial deposits, archaeological features and peat bogs [Dataset], Dryad, https://doi.org/10.5061/dryad.sj3tx963f, 2020.

Scherer, S., Deckers, K., Dietel, J., Fuchs, M., Henkner, J., Höpfer, B., Junge, A., Kandeler, E., Lehndorff, E., Leinweber, P., Lomax, J., Miera, J., Poll, C., Toffolo, M. B., Knopf, T., Scholten, T., and Kühn, P.: What's in a colluvial deposit? Perspectives from archaeopedology, Catena, 198, 1-15, https://doi.org/10.1016/j.catena.2020.105040, 2021.

Scheu, S.: Automated measurement of the respiratory response of soil microcompartments: active microbial biomass in earthworm faeces, Soil Biol. Biochem., 24, 1113-1118, https://doi.org/10.1016/0038-0717(92)90061-2, 1992.

Schöbel, G.: Die Spätbronzezeit am nordwestlichen Bodensee: Taucharchäologische Untersuchungen in Hagnau und Unteruhldingen 1982-1989, in: Forschungen und Berichte zur Vorund Frühgeschichte in Baden-Württemberg, 9-202, 1996.

Schreiner, A.: Hegau und westlicher Bodensee - Sammlung Geologischer Führer, 62 pp., Germany, 2008.

Schroedter, T. M., Dreibrodt, S., Hofmann, R., Lomax, J., Müller, J., and Nelle, O.: Interdisciplinary interpretation of challenging archives: Charcoal assemblages in Drina Valley alluvial and colluvial sediments (Jagnilo, Bosnia and Herzegovina), Quatern. Int., 289, 36-45, https://doi.org/10.1016/j.quaint.2012.02.030, 2013.

Schulte, A. and Stumböck, M.: Late glacial and Holocene environmental changes in the Hegau Region, Southwest Germany, AUC Geographica, 25, 85-97, 2000.

Schweingruber, F. H.: Microscopic Wood Anatomy: Mikroskopische Holzanatomie, Anatomie microscopique du bois, Birmensdorf, Eidgenössische Forschungsanstalt für Wald, Schnee und Landschaft in Bern, Birmensdorf, Switzerland, 1990a.

Schweingruber, F. H.: Anatomie europäischer Hölzer: Ein Atlas zur Bestimmung europäischer Baum-, Strauch- und Zwergstrauch- 
hölzer, Anatomy of European woods/An atlas for the identification of European trees, shrubs and dwarf shrubs, Eidgenössische Forschungsanstalt für Wald, Schnee und Landschaft in Bern, Birmensdorf, Switzerland, 1990b.

Simpson, I. A., van Bergen, P. F., Perret, V., Elhmmali, M. M., Roberts, D. J., and Evershed, R. P.: Lipid biomarkers of manuring practice in relict anthropogenic soils, Holocene, 9, 223-229, https://doi.org/10.1191/095968399666898333 1999.

Skujiòs, J. J. and McLaren, A. D.: Persistence of enzymatic activities in stored and geologically preserved soils, Enzymologia, 34, 213-225, 1968.

Smolders, E. and Mertens, J.: Cadmium, Heavy Metals in Soils: Trace Metals and Metalloids in Soils and their Bioavailability, Environ. Pollut., 22, 283-312, 2013.

Steinhof, A., Altenburg, M., and Machts, H.: Sample Preparation at the Jena ${ }^{14} \mathrm{C}$ Laboratory, Radiocarbon, 59, 815-830, https://doi.org/10.1017/RDC.2017.50, 2017.

Stephan, E.: Die Tierknochenfunde aus der früh- bis mittelbronzezeitlichen Siedlung im "Forschner" Federseemoor, in: Die früh- und mittelbronzezeitliche "Siedlung Forschner" im Federseemoor, Naturwissenschaftliche Untersuchungen, Bohlenwege, Einbäume und weitere botanische Beiträge, Siedlungsarchäologie im Alpenvorland XIII, Forsch. u. Ber. Vor- u. Frühgesch. Baden-Württemberg, 195-283, 2016.

Stika, H.-P. and Heiss, A.: Bronzezeitliche Landwirtschaft in Europa - Der Versuch einer Gesamtdarstellung des Forschungsstandes, in: Studien zur nordeuropäischen Bronzezeit, edited by: Willroth, K.-H., 189-222, 2013.

Stiner, M. C., Kuhn, S. L., Weiner, S., and Bar-Yosef, O.: Differential burning, recrystallization, and fragmentation of archaeological bone, J. Archaeol. Sci., 22, 223-237, https://doi.org/10.1006/jasc.1995.0024, 1995.

Stoops, G.: Guidelines for analysis and description of soil and regolith thin sections, Soil Sci. Soc. Am. J., John Wiley and Sons, 2nd Edn., 241 pp., 2003.

Stuiver, M. and Polach, H. A.: Discussion reporting of ${ }^{14} \mathrm{C}$ data, Radiocarbon, 19, 355-363, https://doi.org/10.1017/S0033822200003672, 1977.

Tan, Z., Wu, C., Han, Y., Zhang, Y., Mao, L., Li, D., Liu, L., Su, G., and Yan, T.: Fire history and human activity revealed through poly cyclic aromatic hydrocarbon (PAH) records at archaeological sites in the middle reaches of the Yellow River drainage basin, China, Palaeogeogr. Palaeocl., 560, 1-12, https://doi.org/10.1016/j.palaeo.2020.110015, 2020.

Taylor, J. P., Wilson, B., Mills, M. S., and Burns, R. G.: Comparison of microbial numbers and enzymatic activities in surface soils and subsoils using various techniques, Soil Biol. Biochem., 34, 387-401, 2002.

Tegtmeier, U.: Neolithische und bronzezeitliche Pflugspuren in Norddeutschland und in den Niederlanden, Archäologische Informationen, 10 pp., 1987.

Tinner, W., Lotter, A. F., Ammann, B., Conedera, M., Hubschmid, P., van Leeuwen, J. F., and Wehrli, M.: Climatic change and contemporaneous land-use phases north and south of the Alps $2300 \mathrm{BC}$ to $800 \mathrm{AD}$, Quaternary Sci. Rev., 22, 1447-1460, https://doi.org/10.1016/S0277-3791(03)00083-0, 2003.

Tsartsidou, G., Lev-Yadun, S., Albert, R.-M., Miller-Rosen, A., Efstratiou, N., and Weiner, S.: The phytolith archaeological record: strengths and weaknesses evaluated based on a quantitative mod- ern reference collection from Greece, J. Archaeol. Sci., 34, 1262 1275, https://doi.org/10.1016/j.jas.2006.10.017, 2007.

Tserendorj, G., Marinova, E., Lechterbeck, J., Behling, H., Wick, L., Fischer, E., Sillmann, M., Märkle, T., and Rösch, M.: Intensification of agriculture in southwestern Germany between Bronze Age and Medieval period, based on archaeobotanical data from Baden-Württemberg, Veg. Hist. Archaeobot., 30, 3546, https://doi.org/10.1007/s00334-020-00814-x, 2021.

Tudyka, K., Bluszcz, A., Poręba, G., Miłosz, S., Adamiec, G., Kolarczyk, A., Kolb, T., Lomax, J., and Fuchs, M.: Increased dose rate precision in combined $\alpha$ and $\beta$ counting in the $\mu$ Dose system - a probabilistic approach to data analysis, Radiat. Meas., 134, https://doi.org/10.1016/j.radmeas.2020.106310, 2020.

Twardy, J.: Influences of man and climate changes on relief and geological structure transformation in Central Poland since the Neolithic, Geographia Polonica, 84, 163-178, 2011.

Twiss, P. C., Suess, E., and Smith, R. M.: Morphological classification of grass phytoliths, Soil Sci. Soc. Am. J., 33, 109-115, 1969.

Usai, M. R.: Textural Pedofeatures and Pre-Hadrian's Wall Ploughed Paleosols at Stanwix, Carlisle, Cumbria, UK, J. Archaeol. Sci., 28, 541-553, https://doi.org/10.1006/jasc.2001.0609, 2001.

van der Knaap, W. O. and Van Leeuwen, J. F. N.: Vegetationsgeschichte und menschlicher Einfluss in der Umgebung des Bibersees zwischen 2600 und 50 v. Chr., in: Cham-Oberwil, Hof (Kanton Zug), Befunde und Funde aus der Glockenbecherkultur und Bronzezeit, edited by: Gnepf-Horisberger, U. and Hämmerle, S., 181-194, 2001.

Vogt, R.: Kolluvien als Archive für anthropogen ausgelöste Landschaftsveränderungen an Beispielen aus der westlichen Bodenseeregion, Materialhefte zur Archäologie in BadenWürttemberg, 99 pp., 2014.

Völkel, J.: Bodenbelastung durch Schwermetalle, in: Nationalatlas Bundesrepublik Deutschland, Leibniz-Institut für Länderkunde, 112-113, 2003.

Vrška, T., Adam, D., Hort, L., Koláŕ, T., and Janík, D.: European beech (Fagus sylvatica L.) and silver fir (Abies alba Mill.) rotation in the Carpathians - A developmental cycle or a linear trend induced by man?, Forest Ecol. Manag., 258, 347-356, https://doi.org/10.1016/j.foreco.2009.03.007, 2009.

Weißkopf, A., Harvey, E., Kingwell-Banham, E., Kajale, M., Mohanty, R., and Fuller, D. Q.: Archaeobotanical implications of phytolith assemblages from cultivated rice systems, wild rice stands and macro-regional patterns, J. Archaeol. Sci., 51, 43-53, https://doi.org/10.1016/j.jas.2013.04.026 2014.

Whitlock, C. and Larsen, C.: Charcoal as a fire proxy, in: Tracking environmental change using lake sediments, edited by: Smol, J. B. and Birks, H. J. B., Last Springer W. M., 75-97, 2002.

Winiwarter, V. and Bork, H.-R.: Geschichte unserer Umwelt: SechzigReisen durch die Zeit, Primus-Verlag and WBG, Darmstadt, Germany, 208 pp., 2019.

Wissert, R.: Hilzingen Binningen (Kreis Konstanz), in: Fundberichte aus Baden-Württemberg, 483 pp., 1985.

Yunker, M. B., Macdonald, R. W., Vingarzan, R., Mitchell, R. H., Goyette, D., and Sylvestre, S.: PAHs in the Fraser River basin: A critical appraisal of PAH ratios as indicators of PAH source and composition, Org. Geochem., 33, 489-515, https://doi.org/10.1016/S0146-6380(02)00002-5, 2002. 
Young, S. D.: Chemistry of heavy metals and metalloids in soils, in: Heavy metals in soils, edited by: Alloway, B. J., 51-95, 2013.

Zádorová, T. and Pení žek, V.: Formation, morphology and classification of colluvial soils: A review, Eur. J. Soil Sci., 69, 577-591, https://doi.org/10.1111/ejss.12673, 2018.
Zádorová, T., Penížek, V., Šefrna, L., Drábek, O., Mihaljevič, M., Volf, Š., and Chuman, T.: Identification of Neolithic to Modern erosion-sedimentation phases using geochemical approach in a loess covered sub-catchment of South Moravia, Czech Republic, Geoderma, 195, 56-69, https://doi.org/10.1016/j.geoderma.2012.11.012, 2013. 